ZENTRUM

FÜR BIODIVERSITÄT UND NACHHALTIGE LANDNUTZUNG

SEKTION

BIODIVERSITÄT, ÖKOLOGIE UND NATURSCHUTZ

- Centre of Biodiversity and Sustainable Land USe -

Section: Biodiversity, Ecology and Nature Conservation

\title{
Changes in trophic structure of decomposer communities with land use in Central European temperate forests
}

\author{
Dissertation zur Erlangung des Doktorgrades der \\ Mathematisch-Naturwissenschaftlichen Fakultäten der \\ Georg-August-Universität Göttingen
}

vorgelegt von

Diplom-Biologe

Bernhard Klarner

aus

Schwerte

Göttingen, September 2013 
Referent: Prof. Dr. Stefan Scheu

Korreferent: PD Dr. Mark Maraun

Tag der mündlichen Prüfung: 20.01.2014 


\section{Table of contents}

Summary

6

\section{Chapter 1}

General introduction

8

The state of Central European temperate forests 9

Soil animal communities as affected by forest management

9

Stable isotope analysis as tool for analyzing the structure of soil animal communities

The Biodiversity Exploratories, a research platform for large-scale and long-term functional biodiversity research

Objectives and chapter outline

References

\section{Chapter 2}

Diversity and functional structure of soil animal communities suggest soil animal food webs to be buffered against changes in forest land use

Abstract

Introduction

Materials and methods

Results

Discussion

Conclusions

Acknowledgements

References 


\section{Chapter 3}

Trophic shift of soil animal species with forest type as indicated by stable isotope analysis

Abstract

Introduction

Materials and methods

Results

Discussion

Conclusions

Acknowledgements

References

\section{Chapter 4}

Trophic diversity and niche partitioning in a species rich predator guild natural variations in stable isotope ratios $\left({ }^{13} \mathrm{C} /{ }^{12} \mathrm{C},{ }^{15} \mathrm{~N} /{ }^{14} \mathrm{~N}\right)$ of mesostigmatid mites (Acari, Mesostigmata) from Central European beech forests

Abstract

Introduction

Materials and methods

Results

Discussion

Conclusions

Acknowledgements 


\section{Chapter 5}

$\begin{array}{ll}\text { General discussion } & 82\end{array}$

$\begin{array}{ll}\text { References } & 86\end{array}$

$\begin{array}{ll}\text { Acknowledgements } & 90\end{array}$

$\begin{array}{ll}\text { List of publications } & 91\end{array}$

$\begin{array}{ll}\text { Thesis declarations } & 92\end{array}$

Supplementary material - Chapter $2 \quad 93$

Supplementary material - Chapter $3 \quad 109$

$\begin{array}{ll}\text { Supplementary material - Chapter } 4 & 119\end{array}$ 


\section{Summary}

Soil animals affect major ecosystem processes, such as nutrient cycling and soil formation, and thereby play a central role in aboveground - belowground interactions. Soil animal food webs are complex trophic networks comprising a diversity of species and resources. Due to the fact that soil animals are exceptionally diverse and feeding interactions in the soil habitat are obscured from direct observation, the structure and functioning of soil animal food webs are little understood.

The present thesis focuses on the composition and trophic ecology of the soil animal food web of Central European forests and the mechanisms responsible for changes with forest management.

In the first study (Chapter 2) we analyzed effects of forest type and management on species composition and functional structure of soil animal communities in a replicated design including three different study regions. The results show that the turnover of species between forest sites is primarily driven by regional abiotic factors, such as soil $\mathrm{pH}$, but additionally relates to forest type and management. Soil animal communities of coniferous forests differ most from those of unmanaged beech forests. The analysis of habitat conditions suggests that this is due to increasing disturbance of the microbial decomposer community and decreasing rates of litter decomposition with forest management intensity. However, little changes in functional structure and diversity of soil animal communities with forest type indicate that the architecture of soil animal food webs is buffered against disturbances by forest land use.

The second study (Chapter 3 ) investigated dietary changes of soil animals with forest type and management by analyzing natural variations in stable isotope signatures. The results show that trophic niches of soil animal species are little affected by management of beech forests. However, the signatures suggest that soil animals shift towards utilizing more litter derived nutrients in coniferous forests, with the pattern being consistent across different species and trophic levels. Furthermore, the results indicate that the importance of litter resources for soil animals increases with the thickness of leaf litter layers but is little related to litter C-to-N ratios and concentrations of litter microorganisms. Presumably, thick leaf litter layers hamper the access of soil animals to root derived resources and thereby foster the utilization of leaf litter in coniferous forests. Overall, the results suggest that structural characteristics of organic layers outweigh litter quality as driving factor of soil animal food webs. 
The third study (Chapter 4) focuses on the trophic ecology of mesostigmatid mites (Mesostigmata) in old-growth beech forests. We investigated natural stable isotope signatures of 40 species common in Central European forests. The results show that the prey spectrum of Mesostigmata comprises mostly secondary decomposers with primary decomposers and intra-guild prey being of little importance. Distinct prey spectra of species suggest that trophic niche differentiation facilitates species richness of this diverse predator group. The signatures furthermore indicate that trophic niches are consistent across different sexes and ontogenetic stages. Presumably, Mesostigmata species heavily rely on bacterial and root feeding nematodes as prey and thereby occupy trophic niches inaccessible to larger sized predators. In contrast to larger predators, the trophic position of Mesostigmata is independent from body size, most likely due to the variable body size of their prey.

By uncovering mechanisms responsible for changes in soil animal communities with forest type and details on the trophic ecology of an important predator group, results of this thesis represent major advances in understanding soil animal food webs. 


\section{Chapter 1}

\section{General introduction}

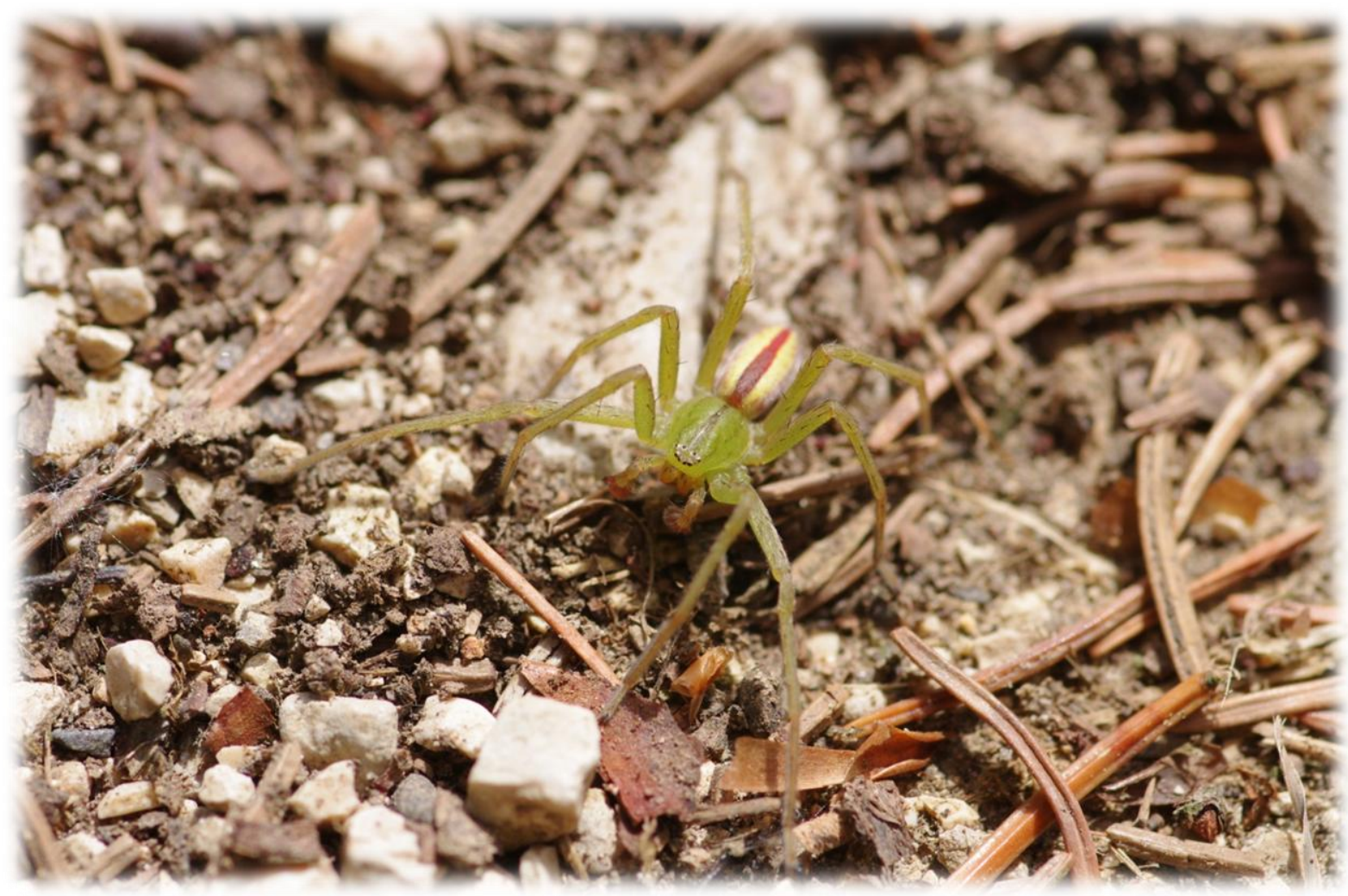

Photo provided by Christian Bluhm 


\section{The state of Central European temperate forests}

Temperate forests are distributed across heavily populated and industrialized parts of the world, such as the eastern part of North America, East Asia and Central Europe (Begon et al. 2006). In Central Europe virtually all forests are influenced by centuries of anthropogenic land use; after being replaced in large by cropland, the remaining forests are integrated into an intensively cultivated landscape. Since the mid of the last century deforestation of temperate forests has effectively stopped to progress (FAO 2012), however, very few Central European forests are in a state that can be regarded as undisturbed. Even though the share of plantation forest is reclining and especially broad leaved forests are increasingly regenerated, most forests are classified as semi-natural reflecting human interventions (MCPFE 2007). The effects of forest management on the structure and growth dynamics of forests are well documented. Forest use has been shown to decrease aboveground biodiversity, mainly by reducing species depending on canopy closure, availability of deadwood and presence of old trees (Bengtsson et al. 2000, Paillet et al. 2010). However, there is a lack of knowledge in a number of animal groups (Paillet et al. 2010), including the belowground system and its community of soil animals.

\section{Soil animal communities as affected by forest management}

Virtually all soil animals depend to some extent on energy originating from the decomposer system and dead organic resources, even those of high trophic levels. Soil food webs therefore are regarded as decomposer or brown food webs (Moore and DeRuiter 1991). Soil animal decomposers fundamentally influence the decomposition of plant litter and take part in soil formation processes (Giller 1996, Hättenschwiler et al. 2005); the structure and functioning of soil animal communities therefore is directly linked to ecosystem services provided by the decomposer system. Soil animal diversity has been shown to suffer from disturbances, however, certain species also benefit from short term disturbances of intermediate strength (Giller 1996, Wardle 2002). The composition of soil animal communities therefore provides information on the grade and nature of disturbances. Effects of forest management on soil animals recently received increased attention (Cassagne et al. 2003, Ponge et al. 2003, Chauvat et al. 2011, Erdmann et al. 2012, Hasegawa et al. 2013). However, information on the subject still is limited to few taxonomic groups and forest types; more comprehensive information is needed to better understand the structure and functioning of forest soil food webs as affected by disturbances and forest management. 


\section{Stable isotope analysis as tool for analyzing the structure of soil animal communities}

Trophic relationships in soil food webs are difficult to investigate and to date there is little knowledge on the dietary spectrum of soil animals in the field. This is related to the high diversity of soil communities, resulting in a high number of potential direct and indirect interactions. Furthermore, most soil animals are small and live below the soil surface and therefore are difficult to observe visually (Giller 1996, Scheu and Falca 2000). Information on soil animal diets therefore is based primarily on observations in the laboratory which inadequately represent the complexity of the field situation. To overcome these restrictions, ecologists increasingly employ indirect approaches to investigate feeding interactions and energy flows in soil food webs. In recent years, the analysis of natural variations in stable isotope ratios of carbon and nitrogen has become an invaluable tool to uncover the trophic structure of soil animal food webs (Scheu and Falca 2000, Scheu 2002, Tiunov 2007).

Variations in stable isotope ratios with trophic level are based on the fact that fractionation processes increase concentrations of the heavy nitrogen isotope $\left({ }^{15} \mathrm{~N}\right)$ in body tissues of consumers; this increase generally averages $3.4 \% 0\left({ }^{15} \mathrm{~N} /{ }^{14} \mathrm{~N}\right)$ as compared to a consumers diet (Post 2002, Martinez del Rio et al. 2009). Stable isotope ratios of nitrogen thereby allow estimating the trophic level of species (DeNiro and Epstein 1981, Peterson and Fry 1987, Scheu and Falca 2000). The stable isotope ratios of carbon $\left({ }^{13} \mathrm{C} /{ }^{12} \mathrm{C}\right)$ provide complementary information, the trophic level fractionation for ${ }^{13} \mathrm{C}$ is low averaging about $0.4 \%$ (Post 2002), ${ }^{13} \mathrm{C} /{ }^{12} \mathrm{C}$ ratios of consumers therefore resemble those of their main food resource (DeNiro and Epstein 1978, Peterson and Fry 1987, Post 2002). Conveniently, modern mass spectrometry allows measurement of stable isotope ratios of both elements in parallel from the same sample (Reineking et al. 1993).

The approach led to fundamental progress in soil food web research but also has limitations. Stable isotope ratios are a time integrated measure of an organisms feeding history (Cabana and Rasmussen 1994, Vander Zanden and Rasmussen 1999). Specific trophic links therefore can only be identified in simple systems with few consumers and distinct resources of different isotopic signatures (DeNiro and Epstein 1978, 1981). Such conditions allow quantifying the contribution of different food sources to the nutrition of consumers (Bearhop et al. 1999, Martinez del Rio et al. 2009). In complex systems, such as forest soil food webs, this task is more challenging. In soil it is difficult to identify and separate different basal resources via natural stable isotope signatures (Pollierer et al. 2009). Isotopic labeling allows tracking specific nutrient pathways from plants into soil food webs (Ruf et al. 2006, Pollierer et al. 2007, Eissfeller et al. 2013). However, the approach is more cost intensive and eradicates the information provided by natural variations in stable isotope 
signatures, such as the trophic level of consumers. Analysing natural variations in stable isotope ratios is most valuable for inferring the structure of soil animal food webs at larger scales such as studies focusing on changes in food web structure with the management of forests and agricultural systems.

Food webs are composed of feeding groups (trophic guilds) consisting of species depending on similar prey or resources and therefore are functionally equivalent (Scheu 2002). Variations of natural stable isotope signatures can be used as empirical evidence to ascribe species to functional groups (Gannes et al. 1998, Eggers and Jones 2000) and this has also been applied in soil animal communities (Ponsard and Arditi 2000, Scheu and Falca 2000). In the past decade the method substantially improved our understanding of the trophic ecology of soil animal groups (Schmidt et al. 2004, Schneider et al. 2004, Chahartaghi et al. 2005, Maraun et al. 2011). Recently the use of the method has been extended to also investigate the functioning of soil animal communities (Pollierer et al. 2009). Overall, stable isotope analysis of soil animal communities is a key for understanding both the structure and functioning of soil food webs.

\section{The Biodiversity Exploratories, a research platform for large-scale and long- term functional biodiversity research}

The Biodiversity Exploratories project was established in 2006 to serve as an open research platform and provide the infrastructure for a variety of research projects with an interdisciplinary focus, thereby fostering the collaborative research of functional biodiversity. Its main objectives are understanding the relationship between biodiversity of different taxa and levels, the effects of land use and management on biodiversity and the role of biodiversity for ecosystem processes. Funding for three project phases was provided by the German Science Foundation (DFG Priority Programm 1374) and currently applications for a fourth funding period (2014 - 17) are in progress. To date the Biodiversity Exploratories span about 80 individual research projects, with over 300 people and 33 institutions involved.

The established infrastructure includes a hierarchical set of standardized study plots $(50 \times$ $50 \mathrm{~m}$ in grasslands, $100 \times 100 \mathrm{~m}$ in forests), including a variety of forest and grassland habitats ranging from unmanaged forests and extensively used grasslands to intensively used forests and grasslands. These study plots were established in three different regions of Germany and allow research of land use effects which can be generalized across geographic regions. Within each region the study plots include 500 grassland and 500 forest plots investigated for large-scale analyses of land use and other environmental factors influencing 
biodiversity data. A selected subset of 100 of these sites (50 each in grasslands and forests), the "experimental plots" (EPs), serves as a platform for more in detail biodiversity assessments and environmental monitoring as well as for a number of manipulative experiments. A further subset of eighteen sites (nine each in grasslands and forests), the "very intensive plots" (VIPs), are used for all high detail and labor intensive studies. The hierarchical design was chosen to maximize the opportunities for interdisciplinary syntheses with a high number of parallel investigations on each research plot.

The three study regions include different geographic and geological characteristics. (1) The UNESCO Biosphere Reserve Schorfheide-Chorin is situated in a young glacial landscape in the North-East of Germany, the altitude ranges from 3 - 140 m (a.s.I.), mean annual precipitation is $500-600 \mathrm{~mm}$. The dominant geological substrate is glacial till, forest soils are dominantly Dystric Cambisols, less frequent are Albeluvisols, Podzols and Regosols. (2) The National Park Hainich and the surrounding area (Hainich-Dün) in Central Germany are a moderately hilly landscape with altitudes of $285-550 \mathrm{~m}$ and a mean annual precipitation of $500-800 \mathrm{~mm}$. The dominant geological substrate is loess over Triassic limestone, the soils typically comprise a loamy or clayey texture; Eutric Cambisols, Luvisols and Stagnosols predominate. (3) The UNESCO Biosphere Reserve Swabian Alb is located on a low mountain range in the South-West of Germany, with altitudes of $460-860 \mathrm{~m}$ and mean annual precipitation of $700-1000 \mathrm{~mm}$. The soils developed mostly on Jurassic shell limestone and are rich in clay. The main soil types are Eutric Cambisol and Leptosol.

The subset of forest experimental plots includes all major forest types in the respective region. The plots are at least $200 \mathrm{~m}$ apart from each another, with a minimum distance of $100 \mathrm{~m}$ to the next forest edge. In the Swabian Alb and Schorfheide plots were restricted to Cambisol sites, in the Hainich the soils included Luvisols and Stagnosols. Very intensive plots in forests were selected to include three replicates of major forest types representing stages of increasing land use intensity. Further details on the plot selection and additional information on the Biodiversity Exploratories project are given in Fischer et al. (2010) and the project website (www.biodiversity-exploratories.de).

The studies presented in this thesis were part of the subproject "Litter Links - Changes in soil food web structure of the decomposer system with land use intensity in forest systems". Our main goals were (1) gaining detailed insight into the structure of forest soil food webs and understand their dynamics as affected by land use intensity/forest management, (2) combining modern technologies of food web analyses with cutting edge modeling approaches in collaboration with subproject "ModelWeb". To compile a detailed dataset for our analyses we focused on a selection of sites; we included the "very intensive plots" in forests of the three regions and extended our studies to additional sites chosen from the 
"experimental plots". In total we investigated 16 forest sites per region selected to include four replicates of four forest types representing stages of different forest management intensity. Coniferous forests were taken to represent the most intensively managed forest type, followed by beech stands (Fagus sylvatica) with management intensity decreasing in the order young managed beech (age class stands of $\sim 30 \mathrm{y}$ ), old managed beech (age class stands of $\sim 70 \mathrm{y}$ ) and unmanaged beech (unmanaged for at least $60 \mathrm{y}$ ). Coniferous forests were represented by Norway spruce (Picea abies) in the Swabian Alb and Hainich, and by Scots pine (Pinus sylvestris) in the Schorfheide.

\section{Objectives and chapter outline}

This thesis focuses on the structuring forces responsible for variations in the composition of forest soil animal communities. In Chapter 2, I evaluated a comprehensive empirical dataset on the animal community and environmental properties of the soil habitat in different forest types of the Biodiversity Exploratories; the respective data was compiled by the joined effort of a large number of researchers, their contribution to the dataset are given in the thesis declaration. Chapter 3 and 4 summarize the results of research projects in which I measured stable isotope signatures of soil animal species to investigate the resource use of a representative spectrum of soil animals in different forest types (Chapter 3 ) and the trophic structure of a diverse predator community in old growth beech forests (Chapter 4).

The following outline states the main hypotheses of the respective studies and summarizes the content of the individual chapters:

(1) The composition of soil animal communities reflects in a characteristic way differences between forest types and changes in forest land use (Chapter 2).

(2) The trophic structure of soil animal food webs is similar across different forest types, however, the resource use of basal (decomposer) species changes with forest type due to differences in the availability and quality of litter resources (Chapter 3 ).

(3) The trophic structure of predator communities is determined by body size and differences in the predatory behavior of individual species (Chapter 4).

Chapter 2. To evaluate changes of the soil animal community with forest land use we investigated the species composition of soil animal communities and environmental factors in different forest types. The results suggest that coniferous forests are characterized by high amounts of leaf litter in the litter layer and low microbial biomass concentrations, contrasting 
in particular unmanaged beech forests. However, soil animal diversity and functional community composition differed little between forest types, indicating resilience against disturbance and intensity of forest land use. The results further show that high soil $\mathrm{pH}$ beneficially affects macrofauna decomposers and concentrations of microorganisms in soil. In contrast, mesofauna decomposers benefitted from low soil $\mathrm{pH}$, indicating release from resource competition with macrofauna decomposers. Overall, the results indicate that decomposer communities are structured predominantly by regional abiotic factors exceeding the role of local biotic factors such as forest type.

Chapter 3. By analyzing variations in stable isotope ratios $\left(\delta^{13} \mathrm{C}\right.$ and $\left.\delta^{15} \mathrm{~N}\right)$ of 28 soil animal species in a replicated design over four forest types and across three regions of Germany we show that the trophic structure of the soil food web varies little with forest type whereas resource use of soil animals differs between forest types. The results suggest that compared to beech forests soil animals in coniferous forests utilize more litter derived resources with the pattern being consistent across different species and trophic levels. Notably, this shift correlated closely with the amount of litter resources but little with litter Cto- $\mathrm{N}$ ratio or concentrations of litter microorganisms. The results suggest that structural habitat characteristics such as the thickness of organic layers outweigh litter quality as driving factor for soil animal food webs of temperate forest ecosystems.

Chapter 4. We investigated the feeding ecology of mesostigmatid mites of temperate beech forests by analyzing variations in carbon and nitrogen stable isotope signatures. With 40 species from 14 families covered, the study resolves the trophic structure of this common and abundant predator group in unprecedented detail. By including data on community structure we show that the dominant Mesostigmata species were high in ${ }^{13} \mathrm{C}$ and most likely feed to a large extent on bacterial and root feeding nematodes. Thereby, they occupy a central trophic niche in the soil food web and exploit prey that is inaccessible for large sized predators. Distinct prey spectra of species suggest that trophic niche differentiation facilitates the diversity of soil predators similar to species rich groups of detritivores such as oribatid mites and collembolans. Further and against theoretical considerations we found body size to be a poor predictor of trophic level which has major implications for biomass based modeling approaches of soil food webs. 


\section{References}

Bearhop, S., Thompson, D. R., Waldron, S., Russell, I. C., Alexander, G. \& Furness, R. W. (1999) Stable isotopes indicate the extent of freshwater feeding by cormorants Phalacrocorax carbo shot at inland fisheries in England. Journal of Applied Ecology, 36, 75-84.

Begon, M., Townsend, C. R. \& Harper, J. L. (2006) Ecology - From Individuals to Ecosystems. WileyBlackwell, Oxford.

Bengtsson, J., Nilsson, S. G., Franc, A. \& Menozzi, P. (2000) Biodiversity, disturbances, ecosystem function and management of European forests. Forest Ecology and Management, 132, 39-50.

Cabana, G. \& Rasmussen, J. B. (1994) Modeling food-chain structure and contaminant bioaccumulation using stable nitrogen isotopes. Nature, 372, 255-257.

Cassagne, N., Gers, C. \& Gauquelin, T. (2003) Relationships between Collembola, soil chemistry and humus types in forest stands (France). Biology and Fertility of Soils, 37, 355-361.

Chahartaghi, M., Langel, R., Scheu, S. \& Ruess, L. (2005) Feeding guilds in collembola based on nitrogen stable isotope ratios. Soil Biology \& Biochemistry, 37, 1718-1725.

Chauvat, M., Titsch, D., Zaytsev, A. S. \& Wolters, V. (2011) Changes in soil faunal assemblages during conversion from pure to mixed forest stands. Forest Ecology and Management, 262, 317-324.

DeNiro, M. J. \& Epstein, S. (1978) Influence of diet on distribution of carbon isotopes in animals. Geochimica et Cosmochimica Acta, 42, 495-506.

DeNiro, M. J. \& Epstein, S. (1981) Influence of diet on the distribution of nitrogen isotopes in animals. Geochimica et Cosmochimica Acta, 45, 341-351.

Eggers, T. \& Jones, T. H. (2000) You are what you eat ... or are you? Trends in Ecology \& Evolution, $15,265-266$.

Eissfeller, V., Beyer, F., Valtanen, K., Hertel, D., Maraun, M., Polle, A. \& Scheu, S. (2013) Incorporation of plant carbon and microbial nitrogen into the rhizosphere food web of beech and ash. Soil Biology \& Biochemistry, 62, 76-81.

Erdmann, G., Scheu, S. \& Maraun, M. (2012) Regional factors rather than forest type drive the community structure of soil living oribatid mites (Acari, Oribatida). Experimental and Applied Acarology, 57, 157-169.

FAO (2012) State of the World's Forests. Online at www.fao.org, Rome.

Fischer, M., Bossdorf, O., Gockel, S., Hansel, F., Hemp, A., Hessenmoeller, D., Korte, G., Nieschulze, J., Pfeiffer, S., Prati, D., Renner, S., Schoening, I., Schumacher, U., Wells, K., Buscot, F., Kalko, E. K. V., Linsenmair, K. E., Schulze, E.-D. \& Weisser, W. W. (2010) Implementing large-scale and long-term functional biodiversity research: The Biodiversity Exploratories. Basic and Applied Ecology, 11, 473-485.

Gannes, L. Z., Del Rio, C. M. \& Koch, P. (1998) Natural abundance variations in stable isotopes and their potential uses in animal physiological ecology. Comparative Biochemistry and Physiology a-Molecular \& Integrative Physiology, 119, 725-737.

Giller, P. S. (1996) The diversity of soil communities, the 'poor man's tropical rainforest'. Biodiversity and Conservation, 5, 135-168. 
Hasegawa, M., Okabe, K., Fukuyama, K., Makino, S., Okochi, I., Tanaka, H., Goto, H., Mizoguchi, T. \& Sakata, T. (2013) Community structures of Mesostigmata, Prostigmata and Oribatida in broad-leaved regeneration forests and conifer plantations of various ages. Experimental and Applied Acarology, 59, 391-408.

Hättenschwiler, S., Tiunov, A. V. \& Scheu, S. (2005) Biodiversity and litter decomposition in terrestrial ecosystems. Annual Review of Ecology Evolution and Systematics, 36, 191-218.

Maraun, M., Erdmann, G., Fischer, B. M., Pollierer, M. M., Norton, R. A., Schneider, K. \& Scheu, S. (2011) Stable isotopes revisited: Their use and limits for oribatid mite trophic ecology. Soil Biology \& Biochemistry, 43, 877-882.

Martinez del Rio, C., Wolf, N., Carleton, S. A. \& Gannes, L. Z. (2009) Isotopic ecology ten years after a call for more laboratory experiments. Biological Reviews, 84, 91-111.

MCPFE (2007) State of Europe's forest 2007: The report on sustainable forest management in Europe. Ministerial Conference on the Protection of Forests in Europe. Warsaw.

Moore, J. C. \& DeRuiter, P. C. (1991) Temporal and spatial heterogeneity of trophic interactions within belowground food webs. Agriculture Ecosystems \& Environment, 34, 371-397.

Paillet, Y., Berges, L., Hjalten, J., Odor, P., Avon, C., Bernhardt-Romermann, M., Bijlsma, R. J., De Bruyn, L., Fuhr, M., Grandin, U., Kanka, R., Lundin, L., Luque, S., Magura, T., Matesanz, S., Meszaros, I., Sebastia, M. T., Schmidt, W., Standovar, T., Tothmeresz, B., Uotila, A., Valladares, F., Vellak, K. \& Virtanen, R. (2010) Biodiversity differences between managed and unmanaged forests: Meta-analysis of species richness in Europe. Conservation Biology, 24, 101-112.

Peterson, B. J. \& Fry, B. (1987) Stable isotopes in ecosystem studies. Annual Review of Ecology and Systematics, 18, 293-320.

Pollierer, M. M., Langel, R., Körner, C., Maraun, M. \& Scheu, S. (2007) The underestimated importance of belowground carbon input for forest soil animal food webs. Ecology Letters, 10, 729-736.

Pollierer, M. M., Langel, R., Scheu, S. \& Maraun, M. (2009) Compartmentalization of the soil animal food web as indicated by dual analysis of stable isotope ratios (15N/14N and $13 \mathrm{C} / 12 \mathrm{C})$. Soil Biology \& Biochemistry, 41, 1221-1226.

Ponge, J. F., Gillet, S., Dubs, F., Fedoroff, E., Haese, L., Sousa, J. P. \& Lavelle, P. (2003) Collembolan communities as bioindicators of land use intensification. Soil Biology \& Biochemistry, 35, 813-826.

Ponsard, S. \& Arditi, R. (2000) What can stable isotopes (delta N-15 and delta C-13) tell about the food web of soil macro-invertebrates? Ecology, 81, 852-864.

Post, D. M. (2002) Using stable isotopes to estimate trophic position: Models, methods, and assumptions. Ecology, 83, 703-718.

Reineking, A., Langel, R. \& Schikowski, J. (1993) N-15,C-13-on-line measurement with an elemental analyzer (Carlo-Erba, NA-1500), a modified trapping box and a gas isotope massspectrometer (Finnigan, MAT-251) Isotopenpraxis, 29, 169-174. 
Ruf, A., Kuzyakov, Y. \& Lopatovskaya, O. (2006) Carbon fluxes in soil food webs of increasing complexity revealed by $\mathrm{C}-14$ labelling and $\mathrm{C}-13$ natural abundance. Soil Biology \& Biochemistry, 38, 2390-2400.

Scheu, S. (2002) The soil food web: Structure and perspectives. European Journal of Soil Biology, 38, 11-20.

Scheu, S. \& Falca, M. (2000) The soil food web of two beech forests (Fagus sylvatica) of contrasting humus type: Stable isotope analysis of a macro- and a mesofauna-dominated community. Oecologia, 123, 285-296.

Schmidt, O., Curry, J. P., Dyckmans, J., Rota, E. \& Scrimgeour, C. M. (2004) Dual stable isotope analysis (delta $\mathrm{C}-13$ and delta $\mathrm{N}-15$ ) of soil invertebrates and their food sources. Pedobiologia, 48, 171-180.

Schneider, K., Migge, S., Norton, R. A., Scheu, S., Langel, R., Reineking, A. \& Maraun, M. (2004) Trophic niche differentiation in soil microarthropods (Oribatida, Acari): evidence from stable isotope ratios (N-15/N-14). Soil Biology \& Biochemistry, 36, 1769-1774.

Tiunov, A. V. (2007) Stable isotopes of carbon and nitrogen in soil ecological studies. Biology Bulletin, 34, 395-407.

Vander Zanden, M. J. \& Rasmussen, J. B. (1999) Primary consumer delta C-13 and delta N-15 and the trophic position of aquatic consumers. Ecology, 80, 1395-1404.

Wardle, D. A. (2002) Communities and Ecosystems - Linking the Aboveground and Belowground Components. Princeton University Press, Princeton and Oxford. 


\section{Chapter 2}

\section{Diversity and functional structure of soil animal communities suggest soil animal food webs to be buffered against changes in forest land use}

Bernhard Klarner, Georgia Erdmann, Bernhard Eitzinger, Melanie M. Pollierer, Roswitha B. Ehnes, Christoph Digel, David Ott, Ulrich Brose, Mark Maraun and Stefan Scheu
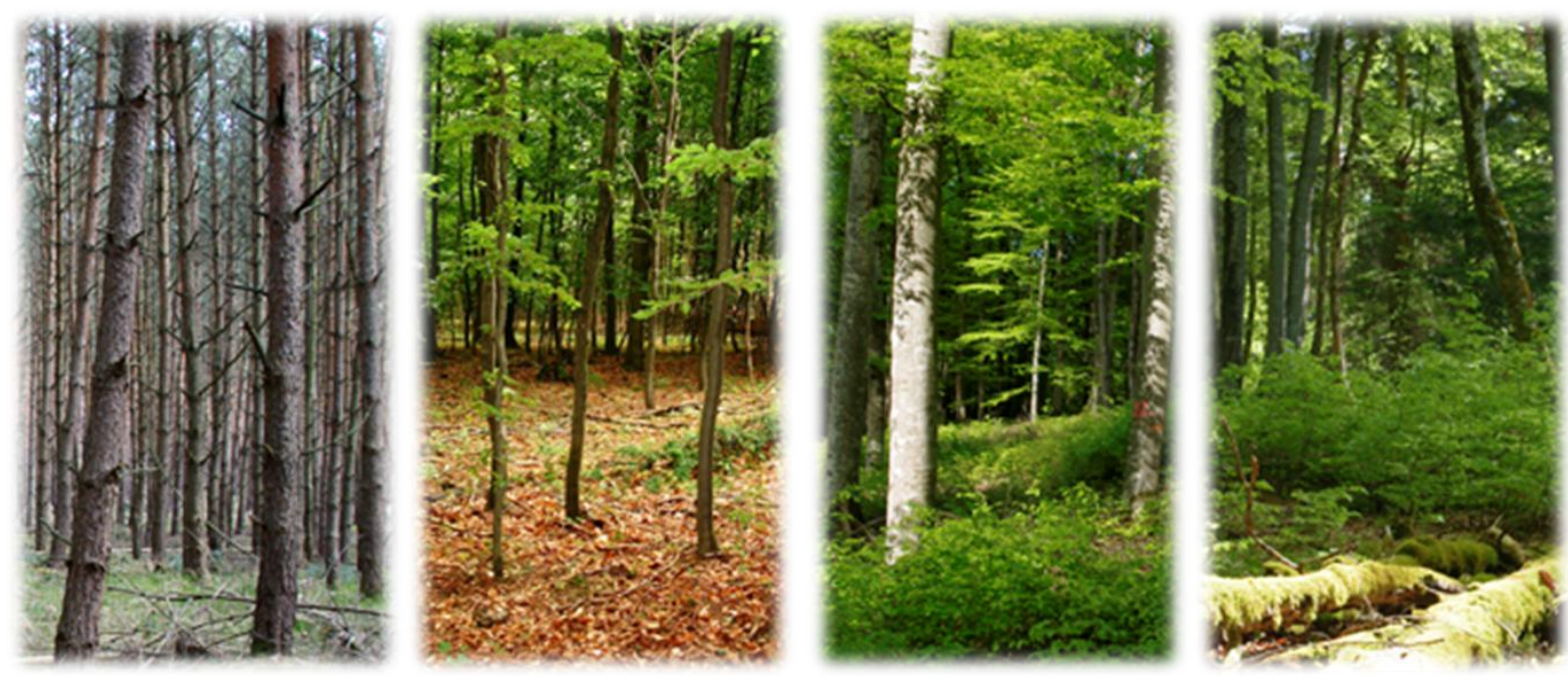

Photos provided by Olga Ferlian and Christian Bluhm 


\section{Abstract}

Forest soil and litter is inhabited by a diverse community of soil animals, which is directly and indirectly sustained by dead organic resources and therefore often paraphrased as the decomposer food web. How this community is affected by habitat changes associated with forest land use is little understood. To evaluate these changes we compiled comprehensive data on the species composition of soil animal communities and environmental factors in different forest types. Four replicates of coniferous, young managed, old managed and unmanaged beech forests were investigated in each of three study regions in Germany with the forest types representing different forest land use intensity. Coniferous forests featured high amounts of leaf litter in the litter layer and low microbial biomass concentrations contrasting in particular unmanaged beech forests. However, soil animal diversity and functional community composition differed little between forest types, indicating resilience against disturbance and intensity of forest land use. Among the environmental factors investigated soil $\mathrm{pH}$ correlated closest with the structure of the soil food web with strong positive effects on macrofauna decomposers and concentrations of microorganisms in soil. In contrast, mesofauna decomposers benefitted from low soil $\mathrm{pH}$, most likely due to release from resource competition with macrofauna decomposers. The strong influence of soil $\mathrm{pH}$ shows that decomposer communities are structured predominantly by regional abiotic factors exceeding the role of local biotic factors such as forest type.

Keywords: soil animal food web, decomposers, forest type, management, disturbance 


\section{Introduction}

Virtually all forests in Central Europe are managed and their natural growth dynamics and overall structure are therefore altered (MCPFE 2007, Fischer et al. 2010). This has been shown to reduce aboveground biodiversity (Bengtsson et al. 2000), which is primarily due to a reduction of species depending on canopy closure, availability of deadwood and presence of old trees (Humphrey et al. 1999, Grove 2002, Paillet et al. 2010). However, little is known on how forest management affects the belowground system and the structure and functioning of soil animal communities, which are an important component of terrestrial ecosystems, e.g., due to their role in decomposition processes and soil formation (Wardle 2002, Bardgett 2005, Hättenschwiler et al. 2005).

Soil animal communities have been shown to be useful indicators of forest condition and disturbance (Bird et al. 2000, Ponge et al. 2003, Cassagne et al. 2006). However, effects of forest management vary depending on forest type and intensity of associated disturbances and also the organism group in focus (Siira-Pietikainen et al. 2001, Chauvat et al. 2003, Chauvat et al. 2011). Furthermore, regional variations of environmental factors, e.g., parent rock, precipitation and mean temperatures, may strongly shape species compositions of soil animal communities and need to be identified for delineating effects associated with forest management. This has recently been documented in detail for the community of oribatid mites (Erdmann et al. 2012).

Soil $\mathrm{pH}$ fundamentally affects the availability and structure of basal resources of soil food webs, e.g., by changing the species composition of the microbial community (Ruess et al. 1996, Lauber et al. 2008, Rousk et al. 2010) and altering fungi-to-bacteria ratios (Blagodatskaya and Anderson 1998, Högberg et al. 2007, Rousk et al. 2009, 2010). Acidic and base rich soils feature distinctively different communities of decomposer animals, with macrofauna decomposers, such as earthworms, diplopods and isopods, reaching highest densities in calcareous soils, whereas mesofauna decomposers, such as Oribatida and Collembola, dominate in acidic soils (Schaefer and Schauermann 1990). Macrofauna decomposers process large amounts of leaf litter (Curry and Schmidt 2006), whereas most mesofauna decomposers, by feeding on litter colonizing fungi and bacteria, translocate nutrients derived from litter into the soil, but contribute little to degradation of litter material (Chamberlain et al. 2006). As a consequence the functional composition of the decomposer community may influence the turnover of organic matter and the nutrient status of soils (Schaefer and Schauermann 1990, Hättenschwiler et al. 2005). However, the turnover of organic matter itself can be an important factor influencing the composition of soil animal communities (Berg and Bengtsson 2007) and may be related to forest use (Erdmann et al. 2012). Macrofauna decomposers thereby may act as keystone species; by processing leaf 
litter material this functional group reduces the availability of habitat structure and resources for other soil animals, especially litter inhabiting mesofauna (Hättenschwiler et al. 2005). This non-trophic interaction between macro- and mesofauna decomposers, due its one-sided nature, has been described as amensalism (Eisenhauer 2010). However, both trophic and non-trophic interactions between soil animal species, size groups and trophic groups vary with environmental factors.

To contribute to the understanding of these interdependencies and to gain insight into effects of forest management on the belowground system we investigated soil animal communities at high taxonomic resolution over a replicated design spanning four different forest types in each of three different regions. Additionally, a comprehensive set of environmental variables was measured at each study site. Using this comprehensive dataset we analyzed how the diversity, species composition and functional structure of soil animal communities are influenced by forest type / management and evaluated the underlying mechanisms.

We expected that soil animal communities differ between forest types with the differences varying between regions; i.e., we hypothesize that (1) disturbance and habitat modification associated with management in the different forest types negatively affect the biodiversity of soil animals, resulting in highest species numbers in unmanaged beech forests. Further, we hypothesized that (2) the functional structure of soil animal communities differs between forest types, with low number and biomasses of large (macrofauna) decomposers in coniferous and young managed beech forests, due to low nutritional quality of the leaf litter resource and disturbance of the microbial community. Finally, we hypothesized that (3) number and biomasses of small (mesofauna) decomposers and associated predators to be highest in coniferous forests and young managed beech forest types, due to thick leaf litter layers providing ample amounts of habitat structure for mesofauna species.

\section{Materials and methods}

\subsection{Study sites}

Four replicates of four forest types representing stages of different forest management intensity were sampled in each of three regions of Germany, i.e. Swabian Alb, Hainich-Dün (Hainich) and Schorfheide-Chorin (Schorfheide). The forest types included coniferous forests, age class stands of young beech (Fagus sylvatica) with an approximate age of 30 years (young managed beech), mature age class stands of beech with an age of approximately 70 years (old managed beech) and mature beech stands which have been left 
unmanaged for at least 60 years (unmanaged beech). Coniferous forests were represented by Norway spruce (Picea abies) in the Swabian Alb and Hainich, but by Scots pine (Pinus sylvestris) in the Schorfheide. Compared to the natural vegetation of deciduous trees in Central Europe (predominantly beech), coniferous forests represent the most intensively managed forest type, followed by the beech stands in the order young managed beech, old managed beech and unmanaged beech. The study sites form part of the "Biodiversity Exploratories" a large integrative biodiversity research project in Germany (www.biodiversityexploraties.de). The three regions (Exploratories) differ in geology and altitude; the Schorfheide is located in a glacial landscape in the north-east of Germany (3 - $140 \mathrm{~m}$ a.s.l.), the Hainich is located in the moderately hilly landscape of Central Germany (285 - $550 \mathrm{~m}$ a.s.I.) and the Swabian Alb in the low mountain range of south-western Germany (480 - 860 m). Swabian Alb and Hainich both feature calcareous bedrock and soils with high clay content, whereas the soils in the Schorfheide range from sandy loam to almost pure sand (Fischer et al. 2010).

\subsection{Sampling and extraction of soil animals}

In spring 2008 two large $(20 \mathrm{~cm} \varnothing)$ and two small soil cores $(5 \mathrm{~cm} \varnothing)$ were taken at random from a $5 \times 5 \mathrm{~m}$ subplot on each site. Soil animals were extracted by heat (Macfadyen 1961, Kempson et al. 1963); from large soil cores Araneae, Chilopoda, Coleoptera, Diplopoda, Diplura, Isopoda, Pseudoscorpiones and Symphyla were analyzed; from small soil cores Collembola, Oribatida and Mesostigmata were analyzed. Lumbricidae were extracted from each site using mustard solution (Gunn 1992, Eisenhauer et al. 2008). The solution was prepared by mixing $100 \mathrm{mg}$ of mustard powder (Semen Sinapis plv., Caesar \& Loretz $\mathrm{GmbH}$, Hilden, Germany) with 10 I of water. The mixture was left to steep over night. At each plot an area of $50 \times 50 \mathrm{~cm}$ was confined using a steel frame, leaf litter was removed and hand sorted for Lumbricidae, $5 \mathrm{I}$ of mustard solution was applied to the soil surface; Lumbricidae were collected during the following $15 \mathrm{~min}$, then another $5 \mathrm{I}$ of solution was applied and Lumbricidae were collected for another $15 \mathrm{~min}$. To include large mobile soil animals, surface active macrofauna and Gastropoda were sampled in spring 2011 from the same subplots as the ones sampled in 2008. On each subplot four randomly selected $50 \mathrm{x}$ $50 \mathrm{~cm}$ areas were confined using a steel frame to prevent escape of mobile animals. Leaf litter material in the confined area was sieved (1 cm mesh width) over plastic trays and animals were collected. Specimens were stored in $70 \%$ ethanol until determination. Species were identified using the following keys: Beier (1963), Eason (1964), Freude et al. (19642004), Klausnitzer (1978), Gisin (1984), Karg (1989), Klausnitzer (1991-2001), Bogon (1990), 
Heimer and Nentwig (1991), Hopkin (1991), Karg (1993), Weigmann (2006), Hopkin (2007), Bährmann (2008) and Schaefer (2010).

For counting species abundances and species numbers all subsamples were added, mean abundances were calculated for species sampled by litter sieving and heat extraction of soil cores. For the calculation of the population biomass of species, either individual body masses were weighed or body lengths were measured and body masses calculated via mass-length regressions (see Ehnes et al. 2011).

\subsection{Assessment of environmental factors}

The amount of leaf litter in the litter layer was determined by weighing the leaf material of each large soil core after animal extraction. Soil pH was measured in $0.01 \mathrm{M} \mathrm{CaCl}_{2}$ solution. C-to- $\mathrm{N}$ ratios of litter, fine root and soil material from macrofauna soil cores were measured using an elemental analyzer (NA 1500, Carlo Erba, Milan). Microbial biomass in leaf litter and soil material was assessed by measuring the maximum initial respiratory response (MIRR; $\mathrm{mg} \mathrm{O}_{2} \mathrm{~g}^{-1} \mathrm{~h}^{-1}$ ) after glucose addition (SIR method; Anderson and Domsch 1980, Beck et al. 1997) in an automated O2 microcompensation apparatus (Scheu 1992). Glucose (80 and 10 $\mathrm{mg} \mathrm{g}^{-1}$ dry weight for litter and soil, respectively) was added as an aqueous solution to approximately $1 \mathrm{~g}$ of leaf litter material adjusting the water content to $80-90 \%$ of the water holding capacity (Joergensen and Scheu 1999, Beck et al. 1997).

\subsection{Data analysis}

Canonical Correspondence Analysis (CCA) was applied to analyze the response of species to the environmental factors differing between the regions and forest types using CANOCO 4.5 (Jongman et al. 1995, ter Braak and Smilauer 2002). The analysis was restricted to species present on at least three sites. The forest types of each region were coded as supplementary variables.

For further statistical analyses all species were assigned to functional groups according to body size (macro- and mesofauna; Swift et al. 1979, Schaefer and Schauermann 1990) and feeding type (decomposers, herbivores, predators) based on literature data and available stable isotope values (Klarner et al. 2013, in prep.). Mesofauna included taxonomic groups typically not exceeding $1-2 \mathrm{~mm}$ in body length as adults (Collembola, Oribatida, Mesostigmata), macrofauna included taxonomic groups of larger body size. "Decomposers" included microbi-detritivorous species predominantly feeding on plant detritus and/or 
associated microorganisms, and "herbivores" and "predators" predominantly feeding on living plant material and animals, respectively. For a complete list of species and their affiliation to functional groups see supplementary Table A5.

Statistical analyses were performed using R 3.0.1 (R Development Core Team 2013). Prior to analysis data were inspected for heteroscedasticity using Levene's test and logtransformed if necessary to improve homogeneity of variances. Mean values and standard deviation in text and figures are based on non-transformed values.

Multivariate analysis of variance was applied using the datasets for species number, abundances and population biomasses of functional groups to inspect for effects of forest type on these variables. To account for variance caused by regional differences, region was included as block. Similar analyses were applied to investigate the effect of forest type on environmental factors. Univariate analyses of variance were used to inspect the effect of forest type on single variables. In case of significant differences in univariate analyses, Tukey's honestly significant difference test was used to inspect differences between means using the R package multcompView (Graves et al. 2011).

Pearson correlations were used to analyze the interrelation of soil animal biomasses as influenced by environment factors. Based on this correlation matrix a path diagram was constructed in AMOS 5.0.1 (AMOS Development Corporation, Springhouse, USA). Environmental factors which significantly correlated with population biomass variables were selected as independent variables and the respective soil animal population biomasses as dependent variable.

\section{Results}

\subsection{Species composition of soil animal communities}

Overall 562 species of soil animals were identified. The most species rich group were macrofauna predators (179 species), followed by mesofauna decomposers (169 species), mesofauna predators (121 species), macrofauna decomposers (71 species) and macrofauna herbivores (22 species).

Canonical Correspondence Analysis (CCA; Fig. 1) separated forest types of the Schorfheide from those of the Swabian Alb and Hainich along the first axis. The sites correlated with soil microbial biomass and soil $\mathrm{pH}$ corresponding to high microbial biomass and alkaline conditions in the calcareous soils of the Swabian Alb and Hainich as compared to acidic soils with low microbial biomass in soils of the Schorfheide. High soil C-to-N ratios 
of the Schorfheide also contributed to the separation of soil animal communities from this site and the Swabian Alb and Hainich. The second axis separated the Swabian Alb from the Hainich; higher amounts of leaf litter in the Swabian Alb and, to a lesser extent, also higher litter microbial biomass in the Hainich contributed to this separation. Further, the second axis separated the coniferous forests from beech forests in the Schorfheide and Hainich with the amount of leaf litter contributing to this separation. The analysis further reflected that a similar number of species of macrofauna predators and both functional groups of mesofauna were associated with the three Exploratories; in contrast, most species of macrofauna herbivores and decomposers were associated with the Hainich and Swabian Alb, only few species were associated with the Schorfheide.

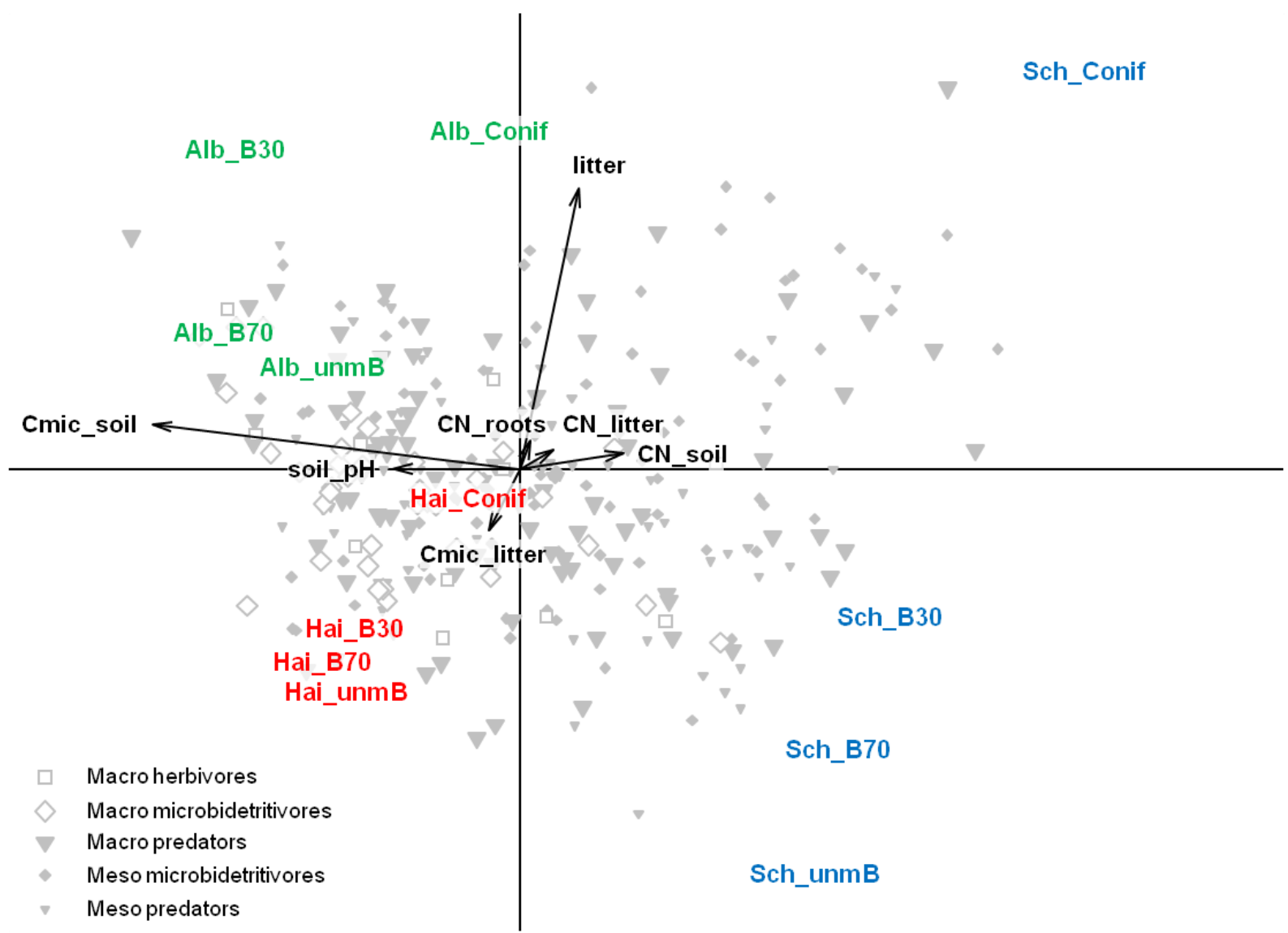

Fig. 1 Canonical Correspondence Analysis (CCA) of soil animal species at different forest types in the three regions investigated $(\mathrm{Alb}=$ Swabian Alb, Hai $=$ Hainich, Sch $=$ Schorfheide, Conif $=$ coniferous forest, $\mathrm{B} 30=$ young managed beech, $\mathrm{B} 70=$ old managed beech, unmB $=$ unmanaged beech) and the environmental factors amount of leaf litter (litter_dw), C-to-N ratio of litter, fine roots and soil (CN_litter, CN_roots, CN_soil, respectively), microbial biomass concentration in soil and litter (Cmic_soil, Cmic_litter, respectively) and soil pH; species are marked by symbols indicating functional group affiliation (see legend); eigenvalues of the first and second axis were 0.28 and 0.14 , respectively. 


\subsection{Characteristics of the soil and litter habitat}

After accounting for regional variations the environmental factors investigated differed significantly between forest types (Table 1). Amount of leaf litter decreased from coniferous over young managed beech to old managed and unmanaged beech forests (Table 1, Fig. 2a). Concentration of microorganisms $\left(C_{\text {mic }}\right)$ in leaf litter increased from coniferous over young and old managed beech to unmanaged beech forests (Table 1, Fig. 2b). Univariate analysis indicated significant differences in soil pH between forest types (Table 1, Fig. 2c). Cto- $\mathrm{N}$ ratio of soil decreased from coniferous over unmanaged and young managed beech to old managed beech forests (Table 1, Fig. $2 d$ ). Concentrations of microorganism in soil $\left(C_{\text {mic }}\right)$ and $\mathrm{C}$-to- $\mathrm{N}$ ratios of leaf litter and fine roots did not differ significantly between forest types (Table 1). Means and standard deviation of each of the environmental factors studied in the different regions and forest types are given in Table A1 (supplementary material).
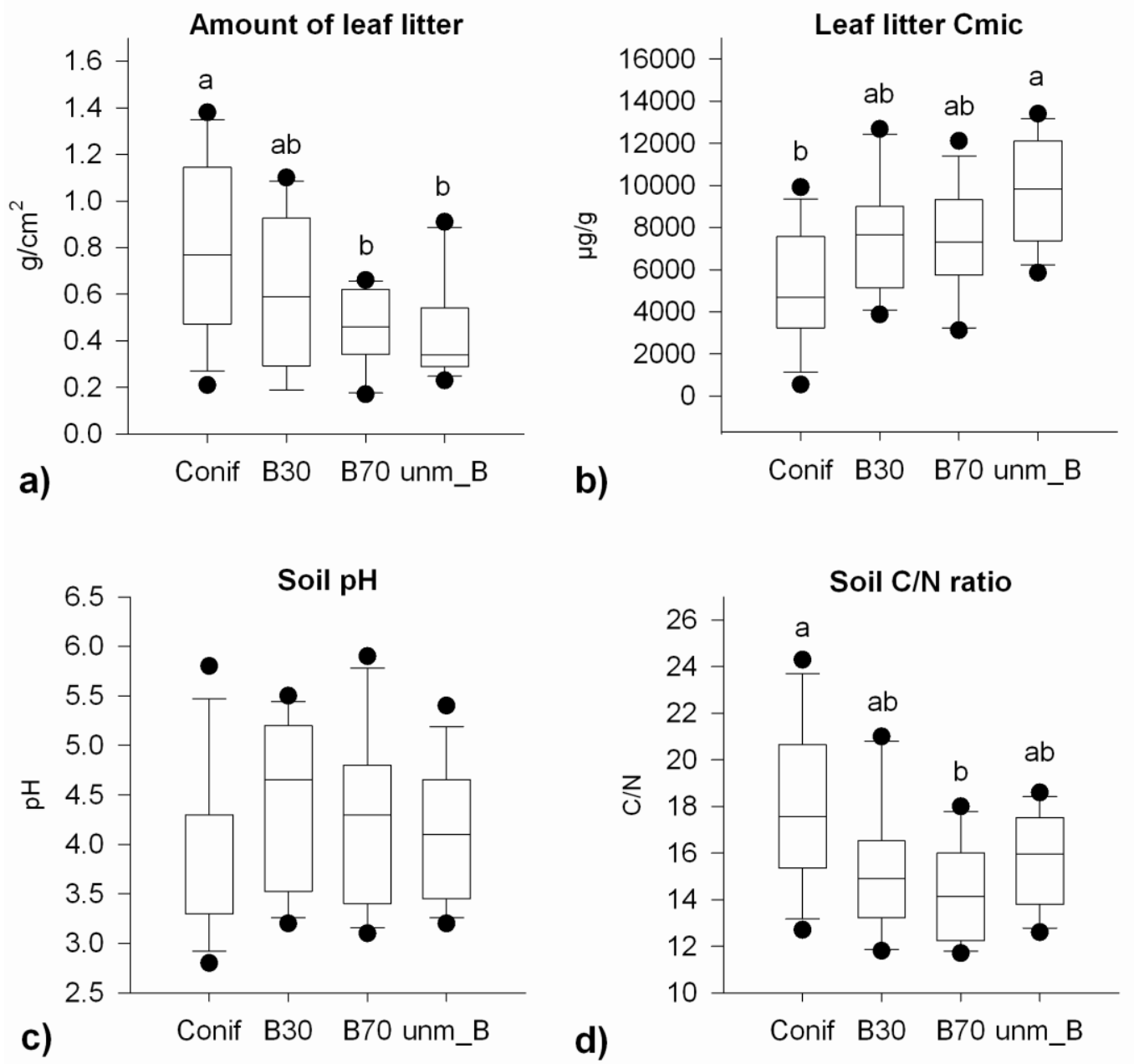

Fig. 2 (a) Amount of leaf litter, (b) microbial biomass concentration in leaf litter, (c) soil pH and (d) Cto- $\mathrm{N}$ ratio of soil in the different forest types investigated (Conif $=$ coniferous forest, $\mathrm{B} 30=$ beech age class $30, \mathrm{~B} 70=$ beech age class $70, \mathrm{unmB}=$ unmanaged beech); boxes indicate the 25 th and 75th percentile, the line in the box marks the median, whiskers map the 90th and 10th percentile, dots display outliers; different letters indicate significant differences between means $(p<0.05$, Tukey's HSD). 
Table 1. Results of multi- and univariate analyses of variance on the effect of forest types on the environmental variables studied; region was included as error term (block factor); significant differences are highlighted in bold, ${ }^{*} p<0.05,{ }^{* *} p<0.01,{ }^{* *} p<0.001$.

\begin{tabular}{|c|c|c|c|}
\hline & Factor & Wilk's $\lambda$ & F-value \\
\hline \multirow{2}{*}{ Multivariate results } & Region & 0.18 & $F_{2,42}=7.07^{\star \star *}$ \\
\hline & Forest_type & 0.27 & $F_{3,42}=2.82^{\star \star \star}$ \\
\hline Variable & Factor & & F-value \\
\hline \multirow{2}{*}{ Amount of leaf litter } & Region & & $F_{2,42}=4.08^{\star *}$ \\
\hline & Forest_type & & $F_{3,42}=4.60^{\star \star}$ \\
\hline \multirow{2}{*}{$\mathrm{C}_{\text {mic }}$ soil } & Region & & $F_{2,42}=19.49^{\star \star \star}$ \\
\hline & Forest_type & & $F_{3.42}=2.04$ \\
\hline \multirow{2}{*}{$\mathrm{C}_{\text {mic }}$ leaf litter } & Region & & $F_{2,42}=3.14$ \\
\hline & Forest_type & & $F_{3,42}=6.83^{\star \star \star}$ \\
\hline \multirow{2}{*}{ Soil pH } & Region & & $F_{2,42}=29.76^{\star \star \star}$ \\
\hline & Forest_type & & $F_{3,42}=3.56^{\star}$ \\
\hline \multirow{2}{*}{ C-to-N leaf litter } & Region & & $F_{2,42}=2.18$ \\
\hline & Forest_type & & $F_{3,42}=0.69$ \\
\hline \multirow{2}{*}{ C-to-N fine roots } & Region & & $F_{2,42}=1.81$ \\
\hline & Forest_type & & $F_{3.42}=2.43$ \\
\hline \multirow{2}{*}{ C-to-N soil } & Region & & $F_{2,42}=15.80^{\star \star \star}$ \\
\hline & Forest_type & & $F_{3,42}=6.30^{\star *}$ \\
\hline
\end{tabular}

\subsection{Diversity and functional structure of the soil animal community}

Species number of soil animals differed significantly between forest types after accounting for regional variations (Table 2). Macrofauna herbivores were more diverse in unmanaged beech compared to old managed beech, values in young managed beech and coniferous forests were intermediate (Table 2, Fig. 3a). For the diversity of mesofauna decomposers the analysis indicated a trend $(p=0.056)$; coniferous forests had higher mean species densities than unmanaged beech forests, with intermediate values in young and old managed beech (Table 2, Fig. 3b). Species number of other soil animal functional groups did not differ significantly between forest types (Table 2). For species number of the other soil animal functional groups in the different regions and forest types investigated refer to Table A2 (supplementary material). 

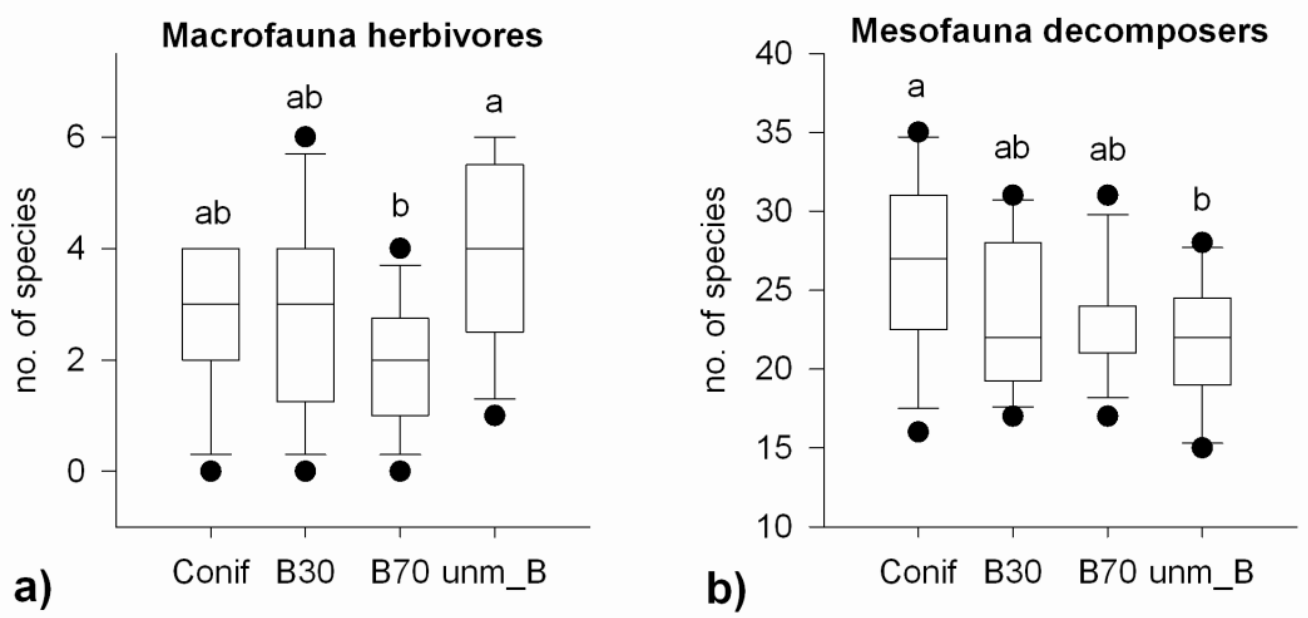

Fig. 3 Number of species of (a) macrofauna herbivores and (b) mesofauna decomposers in different forest types $($ Conif $=$ coniferous forest, B30 $=$ beech age class $30, \mathrm{~B} 70=$ beech age class 70 , unmB = unmanaged beech); boxes indicate the 25th and 75th percentile, the line in the box marks the median, whiskers map the 90th and 10th percentile, dots display outliers; different letters indicate significant differences between means ( $p<0.05$, Tukey's HSD).

Density and biomass of soil animals also differed significantly between forest types (Table 2). Mesofauna decomposers had significantly higher densities in coniferous forests compared to the three types of beech forest investigated (Table 2, Fig. 4a). Their biomass followed a similar pattern, decreasing from coniferous forests over young managed beech to old managed and unmanaged beech (Table 2, Fig. 4b). density and biomass of the other functional groups investigated did not differ significantly between forest types (Table 2). For mean density and biomass of soil animal functional groups in the different regions and forest types investigated refer to the supplementary material (Tables A3 and A4, respectively).
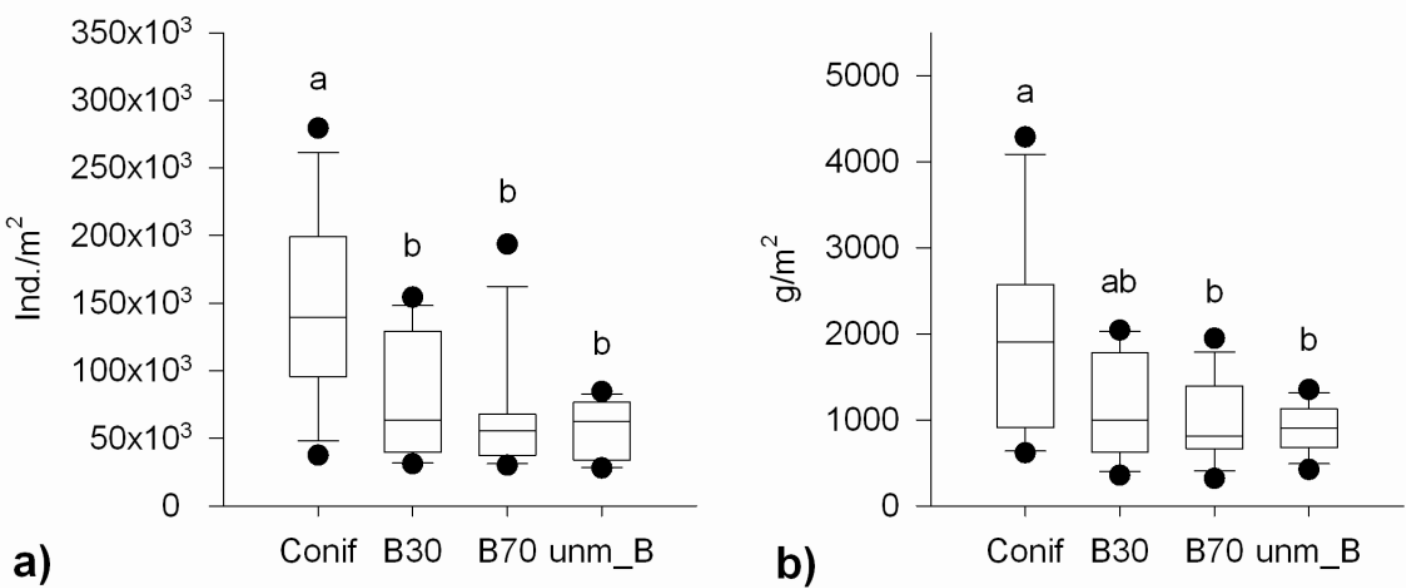

Fig. 4 Abundance (a) and biomass (b) of mesofauna decomposers in different forest types (Conif = coniferous forest, $\mathrm{B} 30=$ beech age class $30, \mathrm{~B} 70=$ beech age class 70, unmB $=$ unmanaged beech); boxes indicate the 25th and 75th percentile, the line in the box marks the median, whiskers map the 90th and 10th percentile, dots display outliers; different letters indicate significant differences between means ( $p<0.05$, Tukey's HSD). 
Table 2. Results of multi- and univariate analyses of variance on the effect of forest types on number of species, density and biomass of different soil animal functional groups; region was included as block; significant differences are highlighted in bold, ${ }^{\star} p<0.05,{ }^{* *} p<0.01,{ }^{* * *} p<0.001$.

\begin{tabular}{|c|c|c|c|c|c|c|c|}
\hline & \multirow[b]{2}{*}{ Factor } & \multicolumn{2}{|c|}{ Species number } & \multicolumn{2}{|c|}{ Abundance } & \multicolumn{2}{|l|}{ Biomass } \\
\hline & & Wilk's $\lambda$ & F-value & Wilk's $\lambda$ & F-value & Wilk's $\lambda$ & F-value \\
\hline \multirow{2}{*}{ Multivariate results } & Region & 0.34 & $F_{2,42}=5.49^{\star \star \star}$ & 0.52 & $F_{2,42}=2.96^{\star \star}$ & 0.51 & $F_{2,42}=3.01^{\star \star}$ \\
\hline & Forest_type & 0.53 & $F_{3,42}=1.83^{\star}$ & 0.45 & $F_{3,42}=2.38^{\star \star}$ & 0.37 & $F_{3,42}=3.03^{\star \star *}$ \\
\hline Functional group & Factor & & Species number & & Abundance & & Biomass \\
\hline \multirow[t]{2}{*}{ Macrofauna decomposers } & Region & & $F_{2,42}=35.23^{\star \star \star}$ & & $F_{2,42}=9.89^{\star \star \star}$ & & $F_{2,42}=11.61^{\star \star \star}$ \\
\hline & Forest_type & & $F_{3,42}=1.95$ & & $\mathrm{~F}_{3,42}=0.91$ & & $F_{3,42}=0.24$ \\
\hline \multirow{2}{*}{ Macrofauna herbivores } & Region & & $F_{2,42}=0.88$ & & $F_{2,42}=0.61$ & & $F_{2,42}=0.93$ \\
\hline & Forest_type & & $F_{3,42}=3.80^{\star}$ & & $F_{3,42}=1.84$ & & $F_{3,42}=1.80$ \\
\hline \multirow{2}{*}{ Macrofauna predators } & Region & & $F_{2,42}=5.29^{\star \star}$ & & $F_{2,42}=0.50$ & & $F_{2,42}=0.58$ \\
\hline & Forest_type & & $F_{3.42}=1.65$ & & $F_{3,42}=1.49$ & & $F_{3.42}=2.45$ \\
\hline \multirow[t]{2}{*}{ Mesofauna decomposers } & Region & & $F_{2,42}=0.84$ & & $F_{2,42}=4.28^{\star}$ & & $F_{2,42}=5.21^{\star \star}$ \\
\hline & Forest_type & & $F_{3,42}=2.73$ & & $F_{3,42}=9.81^{\star \star *}$ & & $F_{3,42}=7.34^{\star \star}$ \\
\hline \multirow{2}{*}{ Mesofauna predators } & Region & & $F_{2,42}=1.61$ & & $F_{2,42}=0.70$ & & $F_{2,42}=1.42$ \\
\hline & Forest_type & & $F_{3,42}=1.40$ & & $F_{3,42}=1.68$ & & $F_{3,42}=1.60$ \\
\hline
\end{tabular}




\subsection{Functional structure of soil animal communities as affected by environmental factors and interrelations between functional groups}

Macrofauna decomposer biomass increased with soil microbial biomass $(r=0.61, p<$ $0.001)$ and soil $\mathrm{pH}(r=0.70, \mathrm{p}<0.001)$ and decreased with soil C-to- $\mathrm{N}$ ratios $(r=-0.38, \mathrm{p}=$ 0.007). The biomass of mesofauna decomposers increased with amount of leaf litter $(r=$ $0.41, p=0.003)$ and $\mathrm{C}$-to-N ratios of fine roots and soil $(r=0.33, p=0.021$ and $r=0.51, p<$ 0.001 , respectively); it decreased with soil microbial biomass $(r=-0.44, p=0.002)$ and soil $\mathrm{pH}(r=-0.59 \mathrm{p}<0.001)$. Mesofauna predator biomasses increased with amount of leaf litter $(r=0.29, p=0.05)$ and C-to- $N$ ratios of fine roots $(r=0.44, p=0.002)$.

The biomass of mesofauna decomposers and mesofauna predators was correlated significantly ( $r=0.34 p=0.019)$; furthermore, the biomass of both groups decreased with the biomass of macrofauna decomposers $(r=-0.57, p<0.001$ and $r=-0.31 p=0.03$, respectively). The full correlation matrix is given in Table 3.

Path analysis suggests that soil $\mathrm{pH}$ beneficially affected microbial biomass in soil as well as macrofauna decomposer biomass. In contrast, it suggests that soil $\mathrm{pH}$ negatively affected $\mathrm{C}$-to- $\mathrm{N}$ ratios of soil and mesofauna decomposer biomass. Furthermore, it suggests that the amount of leaf litter beneficially affected mesofauna decomposer biomass, and that C-to- $\mathrm{N}$ ratio of fine roots beneficially affected mesofauna predators. Overall, by direct and indirect effects the path analysis model explained $50 \%, 49 \%$ and $21 \%$ of the variation in density of mesofauna decomposers, macrofauna decomposers and mesofauna predators (Fig. 5). Unstandardized and standardized regression weights and significance levels are given in Table 4. 


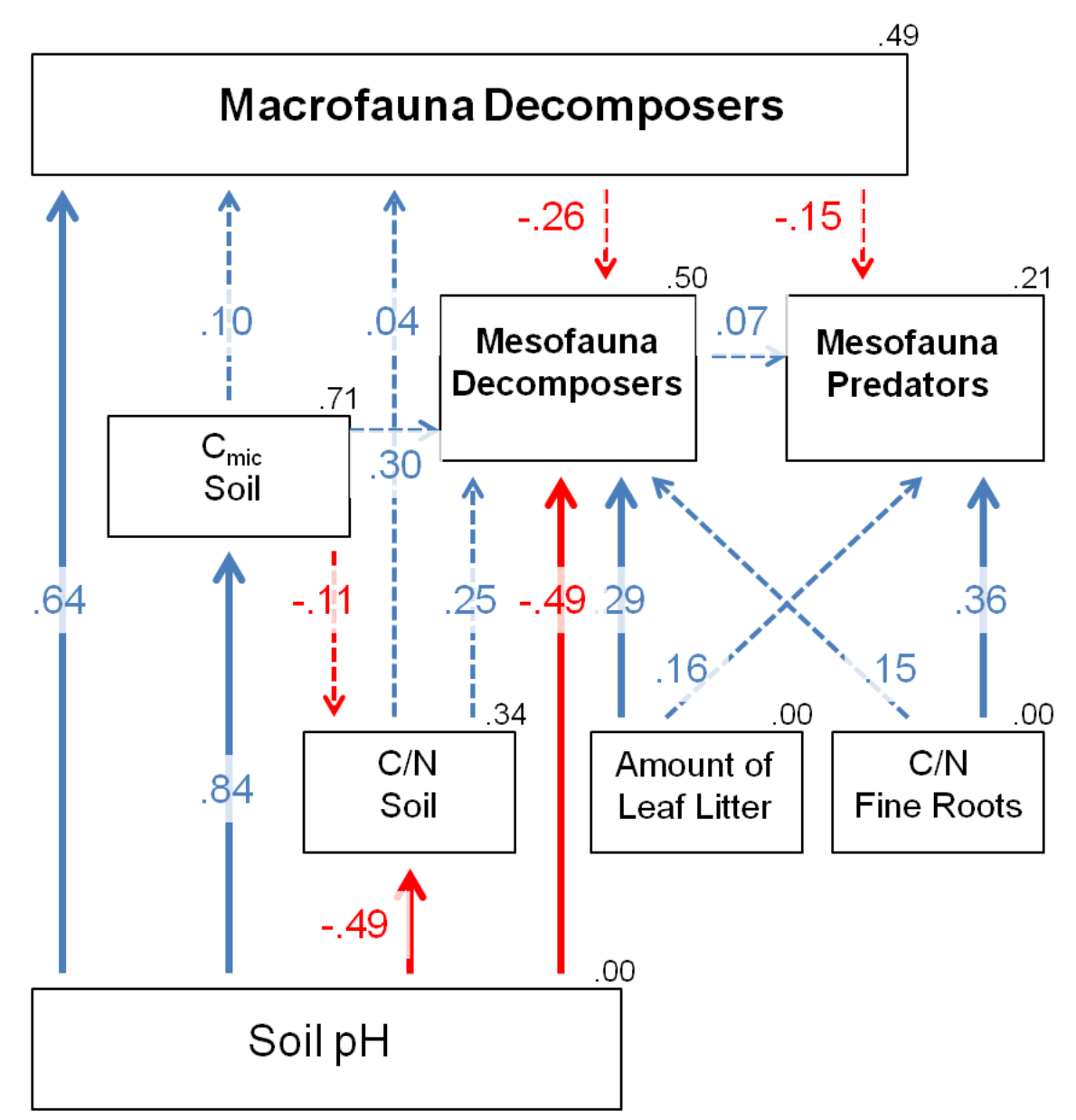

Fig. 5 Path diagram showing the relationship between environmental factors and population biomasses of different soil animal functional groups; solid and dashed arrows connecting boxes show significant and non-significant effects $(p<0.05)$, respectively; numbers on arrows represent standardized regression weights, numbers on the upper right of each box represent squared multiple correlations of the respective variable; $\mathrm{N}=48$, Chi-square $=10.7(\mathrm{df}=12), \mathrm{p}=0.554$. 


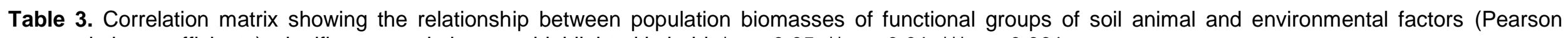
correlation coefficients), significant correlations are highlighted in bold, ${ }^{*} p<0.05,{ }^{* *} p<0.01,{ }^{* * *} p<0.001$.

\begin{tabular}{|c|c|c|c|c|c|c|c|c|c|c|c|c|c|}
\hline & & 1 & 2 & 3 & 4 & 5 & 6 & 7 & 8 & 9 & 10 & 11 & 12 \\
\hline 1 & Amount of leaf litter & - & & & & & & & & & & & \\
\hline 2 & $\mathrm{C}_{\text {mic }}$ soil & -0.18 & - & & & & & & & & & & \\
\hline 3 & $\mathrm{C}_{\text {mic }}$ leaf litter & -0.16 & 0.14 & - & & & & & & & & & \\
\hline 4 & Soil pH & -0.13 & $0.84^{\star \star \star}$ & -0.05 & - & & & & & & & & \\
\hline 5 & C-to-N leaf litter & 0 & -0.01 & -0.03 & -0.07 & - & & & & & & & \\
\hline 6 & C-to-N fine roots & 0.18 & -0.16 & 0.08 & -0.23 & -0.12 & - & & & & & & \\
\hline 7 & C-to-N soil & 0.21 & $-0.52^{\star \star \star}$ & $-0.31^{*}$ & $-0.58^{\star \star \star}$ & $0.29 *$ & 0.11 & - & & & & & \\
\hline 8 & Macrofauna decomposers & -0.26 & $0.61^{\star \star \star}$ & -0.15 & 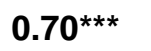 & -0.04 & -0.24 & $-0.38^{\star \star}$ & - & & & & \\
\hline 9 & Macrofauna herbivores & 0.07 & -0.06 & -0.15 & 0.03 & 0.01 & 0.09 & 0.12 & 0.04 & - & & & \\
\hline 10 & Macrofauna predators & -0.16 & -0.1 & 0.23 & -0.09 & -0.13 & -0.08 & 0.05 & -0.1 & 0.06 & - & & \\
\hline 11 & Mesofauna decomposers & $0.41^{\star \star}$ & $-0.44^{\star \star}$ & -0.19 & $-0.59^{\star \star \star}$ & 0.06 & $0.33^{\star}$ & $0.51^{\star \star *}$ & $-0.57^{\star \star \star}$ & -0.1 & -0.13 & - & \\
\hline 12 & Mesofauna predators & $0.29^{\star}$ & -0.15 & 0.06 & -0.24 & -0.17 & $0.44^{\star \star}$ & 0.17 & $-0.31^{\star}$ & -0.14 & -0.04 & $0.34^{\star}$ & - \\
\hline
\end{tabular}


Table 4. Effect sizes of interrelations between environmental variables, effects of environmental variables on soil animal functional groups and interrelations between functional groups; $B=$ unstandardized regression weight, St. error $=$ standard error of $B, \beta=$ standardized regression weight, significant effects $(p<0.05)$ are highlighted in bold.

\begin{tabular}{llrrrr} 
Independend variable & Dependend variable & B & St. error & $\beta$ & $p$ \\
\hline Soil pH & C $_{\text {mic }}$ soil & $\mathbf{5 2 6 . 9 4}$ & $\mathbf{4 9 . 2 6}$ & $\mathbf{0 . 8 4}$ & $<\mathbf{0 . 0 0 1}$ \\
C $_{\text {mic }}$ soil & Soil C/N & 0 & 0 & -0.11 & 0.607 \\
Soil pH & Soil C/N & $\mathbf{- 1 . 7 5}$ & $\mathbf{0 . 7 9}$ & $-\mathbf{0 . 4 9}$ & $\mathbf{0 . 0 2 6}$ \\
\hline Soil pH & Macrofauna decomposers & $\mathbf{2 0 6 0 5 . 9 5}$ & $\mathbf{6 5 0 4 . 3 2}$ & $\mathbf{0 . 6 4}$ & $\mathbf{0 . 0 0 2}$ \\
C $_{\text {mic }}$ soil & Macrofauna decomposers & 4.89 & 9.91 & 0.1 & 0.622 \\
C-to-N soil & Macrofauna decomposers & 368.98 & 1149.89 & 0.04 & 0.748 \\
C-to-N fine roots & Mesofauna decomposers & 23.48 & 16.21 & 0.15 & 0.148 \\
C-to-N soil & Mesofauna decomposers & 63.31 & 32.9 & 0.25 & 0.054 \\
Amount of leaf litter & Mesofauna decomposers & $\mathbf{6 9 8 . 3 5}$ & $\mathbf{2 5 2 . 8 3}$ & $\mathbf{0 . 2 9}$ & $\mathbf{0 . 0 0 6}$ \\
C & Mesofauna decomposers & 0.45 & 0.28 & 0.3 & 0.116 \\
Soil pH & Mesofauna decomposers & $-\mathbf{4 4 8 . 6 1}$ & $\mathbf{2 0 4 . 7 7}$ & $-\mathbf{- 0 . 4 9}$ & $\mathbf{0 . 0 2 8}$ \\
Amount of leaf litter & Mesofauna predators & 195.84 & 170.15 & 0.16 & 0.25 \\
C-to-N fine roots & Mesofauna predators & $\mathbf{2 8 . 9 3}$ & $\mathbf{1 0 . 4 6}$ & $\mathbf{0 . 3 6}$ & $\mathbf{0 . 0 0 6}$ \\
\hline Macrofauna decomposers & Mesofauna predators & 0 & 0 & -0.16 & 0.312 \\
Macrofauna decomposers & Mesofauna decomposers & -0.01 & 0 & -0.26 & 0.077 \\
Mesofauna decomposers & Mesofauna predators & 0.04 & 0.08 & 0.07 & 0.662 \\
\hline
\end{tabular}

\section{Discussion}

\subsection{Relationships between environmental factors and biomass of functional groups of soil animals}

The results suggest that soil pH was the dominant environmental factor affecting the biotic variables investigated. Soil $\mathrm{pH}$ explained large parts of the variation of microbial biomass in soil and closely correlated with the biomass distribution of decomposer animals. As hypothesized biomass of macrofauna decomposers increased with soil $\mathrm{pH}$, reflecting that many species in this functional group prefer calcareous soils, while mesofauna decomposers decreased with soil $\mathrm{pH}$. C-to- $\mathrm{N}$ ratios of soil decreased with soil $\mathrm{pH}$, suggesting that the nutrient status of soils is related to the decomposer community, with the presence of macrofauna decomposers improving the humus type in forests (Schaefer and Schauermann 1990, Ponge et al. 1997, Ponge 2003).

Biomass of mesofauna decomposers correlated positively with the amount of leaf litter at the study sites, supporting the view that thick leaf litter layers foster the community of microbi-detritivorous microarthropods (Eisenhauer 2010, Erdmann et al. 2012). However, path analysis indicated that macrofauna decomposers did not affect the thickness of leaf litter in the forests investigated arguing against our hypothesis that lower biomass of mesofauna 
decomposers in forests growing on calcareous soils compared to acidic soils are due to reduced habitat structure in presence of macrofauna decomposers. The strong effect of soil $\mathrm{pH}$ on mesofauna decomposers shows that $\mathrm{pH}$ related parameters likely also are involved. Based on stable isotope labeling experiments there is increasing evidence that in addition to leaf litter the decomposer system heavily relies on root derived resources (Ruf et al. 2006, Pollierer et al. 2007, Eissfeller et al. 2013). The biomass distribution suggests that macrofauna decomposers more successfully sequester these resources but are more sensitive to increased acidity than mesofauna decomposers.

Biomass of mesofauna predators increased with $\mathrm{C}$-to- $\mathrm{N}$ ratio of fine roots, indicating that this functional group is closely connected to the rhizosphere. Presumably, high C-to-N ratios of fine roots are related to high root growth and exudation, and these characteristics are driven by low nitrogen availability (Boxman et al. 1998, Paterson and Sim 2000). Roots and root colonizing microbes are the main food source for soil nematodes (Bais et al. 2006, Crotty et al. 2011), these in turn are a main prey for predatory microarthropods (Karg 1983, Koehler 1999, Heidemann et al. 2011). Our results suggest that increased root growth and root exudation fosters mesofauna predators via a trophic cascade involving three to four trophic levels.

Biomass of macrofauna herbivores and macrofauna predators were not significantly related to the environmental parameters investigated. Both functional groups include a number of species with high dispersal ability, such as spiders and winged insects, which rely little on local soil characteristics but rather on the structure of the aboveground system.

\subsection{Species composition of the soil animal community as influenced by regional factors and forest type}

Results of the present study suggest that the importance of regional factors surpasses that of forest type in structuring soil animal communities; communities of different forest types within regions were more similar than those of the same forest types of different regions. Investigating oribatid mite communities at the study sites Erdmann et al. (2012) concluded that abiotic factors, such as temperature, precipitation and parent rock, dominate over forest type as structuring forces for this soil arthropod group. Investigating soil animal communities in a more comprehensive way in the present study suggests that the results of Erdmann et al. (2012) apply in large to soil animal communities of temperate forests. Regional factors were particularly important in structuring macrofauna herbivores and decomposers, thriving at the Hainich and Swabian Alb, regions with high soil $\mathrm{pH}$, while the opposite was true for the Schorfheide (see also section 5.1). CCA further showed that 
species composition of coniferous forests differed most from that of unmanaged beech forests in each of the three regions investigated. This indicates that among the management types investigated, habitat conditions in coniferous forests deviate most from those of the presumed natural forest of central Europe dominated by beech.

\subsection{Diversity and functional structure of soil animal communities}

After accounting for regional variability the analysis of environmental factors supports our assumption that the habitat of soil animals is significantly influenced by forest management, i.e. by anthropogenic disturbances. Conform to our hypotheses, the thickness of the leaf litter layer decreased from coniferous forests over young managed beech to mature beech forests. Notably, the opposite was true for microbial biomass concentration in leaf litter which increased from coniferous forests to unmanaged beech forests, suggesting that leaf litter decomposition is negatively affected by disturbance of the microbial community. C-to-N ratios in soil further indicated the nutrient status in old managed beech forests surpasses that in coniferous forests.

In contrast to our hypotheses, the biodiversity and functional composition of the soil animal community was little affected by forest type. With the exception of macrofauna herbivores, the least abundant functional group investigated, the diversity of functional groups of soil animals did not differ between forest types. Macrofauna herbivores were more diverse in unmanaged compared to old managed beech forests, indicating that management reduces the number of niches for plant feeding arthropods in old-growth beech forests. Interestingly, plant diversity at the study sites has been shown to increase with management of old beech stands (Boch et al. 2013). This indicates that the number of trophic niches of soil- and litter-dwelling herbivores is unlikely to be affected directly by the diversity of plants. The animals studied included a large number of root-feeding species, such as curculionid and elaterid beetle larvae, suggesting that natural beech forests including different aged trees provide a higher number of niches for root feeders than age class managed beech forests.

Abundance and biomass of mesofauna decomposers were higher in coniferous forests compared to each of the beech forests investigated. This indicates that the effect of tree species on this functional group of soil animals exceeds that of forest management. Presumably, this is related to the thickness of organic layers in coniferous forests (Erdmann et al. 2012; see above). Abundance and biomass of other functional groups were not affected by forest type suggesting that the functional structure of the soil animal communities varies little with forest management. 
Overall, the results indicate that anthropogenic disturbances associated with the management of European forest only little affects the structure and functioning of soil animal communities. Characteristic features of soil animal food webs, such as the dominance of generalist feeders and redundancy within functional groups, likely buffer its architecture against disturbances (Siira-Pietikainen et al. 2001, Scheu 2002, Cole et al. 2006). Furthermore, soil animal communities presumably recover quickly from disturbances associated with forest management practices; indeed, density and diversity of soil mites have been shown to recover within four years after clear cutting and replanting (Hasegawa et al. 2013). Our data suggest that the structure of soil animal communities of young managed, old managed and unmanaged beech forests is similar in each of the three regions investigated. This supports the view of Swanson et al. (2011) that early succesion stages such as young beech forests may conserve a large fraction of the fauna of old growth forest stands. Results of the study suggest that this even applies to coniferous forests, especially to soil mesofauna.

\section{Conclusions}

The results show that regional variations of environmental factors, in particular those related to parent rock and soil $\mathrm{pH}$, strongly influence the species composition of soil animal communities in managed and unmanaged forests in Central Europe. Locally, however, forest management and forest type affect soil animal communities in particular via changes in environmental factors associated with structural characteristics of the soil and litter habitat. However, diversity, abundance and biomass distribution of functional groups of soil animals are rather insensitive to changes in forest type. This indicates that while individual species may be influenced, the overall structure and functioning of soil animal communities is buffered against anthropogenic disturbances, and ecosystem services provided by soil animals are likely to be maintained even if forests are markedly altered by man. However, to preserve the full complement of soil animal species including rare species unmanaged forests are needed. Considering the turnover of species on regional scales such forests need protection to conserve the diversity of soil animal species.

\section{Acknowledgements}

We thank the managers of the three exploratories, Swen Renner, Sonja Gockel, Kerstin Wiesner, and Martin Gorke for their work in maintaining the plot and project infrastructure; Simone Pfeiffer and Christiane Fischer giving support through the central office, Michael 
Owonibi for managing the central data base, and Markus Fischer, Eduard Linsenmair, Dominik Hessenmöller, Jens Nieschulze, Daniel Prati, Ingo Schöning, François Buscot, Ernst-Detlef Schulze, Wolfgang W. Weisser and the late Elisabeth Kalko for their role in setting up the Biodiversity Exploratories project. Financial support by the German Research Foundation (DFG; Priority Program 1374 "Infrastructure-Biodiversity-Exploratories") is gratefully acknowledged. Field work permits were issued by the state environmental office of Baden-Württemberg, Thüringen, and Brandenburg (§ 72 BbgNatSchG).

\section{References}

Anderson, J. P. E. \& Domsch, K. H. (1980) Quantities of plant nutrients in the microbial biomass of selected soils. Soil Science, 130, 211-216.

Bährmann, R. (2008) Bestimmung wirbelloser Tiere. Gustav Fischer Verlag, Jena and Stuttgart.

Bais, H. P., Weir, T. L., Perry, L. G., Gilroy, S. \& Vivanco, J. M. (2006) The role of root exudates in rhizosphere interations with plants and other organisms. Annual Review of Plant Biologypp. 233-266. Annual Reviews, Palo Alto.

Bardgett, R. D. (2005) The biology of soil - A community and ecosystem approach. Oxford University Press, Oxford.

Beck, T., Joergensen, R. G., Kandeler, E., Makeschin, F., Nuss, E., Oberholzer, H. R. \& Scheu, S. (1997) An inter-laboratory comparison of ten different ways of measuring soil microbial biomass C. Soil Biology \& Biochemistry, 29, 1023-1032.

Beier, M. (1963) Ordnung Pseudoscorpionidea (Afterskorpione). Akademie-Verlag, Berlin.

Bengtsson, J., Nilsson, S. G., Franc, A. \& Menozzi, P. (2000) Biodiversity, disturbances, ecosystem function and management of European forests. Forest Ecology and Management, 132, 39-50.

Berg, M. P. \& Bengtsson, J. (2007) Temporal and spatial variability in soil food web structure. Oikos, $116,1789-1804$.

Bird, S., Coulson, R. N. \& Crossley, D. A. (2000) Impacts of silvicultural practices on soil and litter arthropod diversity in a Texas pine plantation. Forest Ecology and Management, 131, 65-80.

Birkhofer, K., Schoning, I., Alt, F., Herold, N., Klarner, B., Maraun, M., Marhan, S., Oelmann, Y., Wubet, T., Yurkov, A., Begerow, D., Berner, D., Buscot, F., Daniel, R., Diekotter, T., Ehnes, R. B., Erdmann, G., Fischer, C., Foesel, B., Groh, J., Gutknecht, J., Kandeler, E., Lang, C., Lohaus, G., Meyer, A., Nacke, H., Nather, A., Overmann, J., Polle, A., Pollierer, M. M., Scheu, S., Schloter, M., Schulze, E. D., Schulze, W., Weinert, J., Weisser, W. W., Wolters, V. \& Schrumpf, M. (2012) General Relationships between Abiotic Soil Properties and Soil Biota across Spatial Scales and Different Land-Use Types. Plos One, 7, 8.

Blagodatskaya, E. V. \& Anderson, T. H. (1998) Interactive effects of $\mathrm{pH}$ and substrate quality on the fungal-to-bacterial ratio and $\mathrm{QCO}(2)$ of microbial communities in forest soils. Soil Biology \& Biochemistry, 30, 1269-1274.

Boch, S., Prati, D., Müller, J., Socher, S., Baumbach, H., Buscot, F., Gockel, S., Hemp, A., Hessenmöller, D., Kalko, E. K. V., Linsenmair, K. E., Pfeiffer, S., Pommer, U., Schöning, I., 
Schulze, E.-D., Seilwinder, C., Weisser, W. W., Wells, K. \& Fischer, M. (2013) High plant species richness indicates management-related disturbances rather than the conservation status of forests. Basic and Applied Ecology.

Bogon, K. (1990) Landschnecken: Biologie-Ökologie-Biotopschutz. Natur-Verlag, Augsburg.

Boxman, A. W., Blanck, K., Brandrud, T. E., Emmett, B. A., Gundersen, P., Hogervorst, R. F., Kjonaas, O. J., Persson, H. \& Timmermann, V. (1998) Vegetation and soil biota response to experimentally-changed nitrogen inputs in coniferous forest ecosystems of the NITREX project. Forest Ecology and Management, 101, 65-79.

Cassagne, N., Gauquelin, T., Bal-Serin, M. C. \& Gers, C. (2006) Endemic Collembola, Privileged Bioindicators of Forest Management. Pedobiologia, 50, 127-134.

Chamberlain, P. M., Mcnamara, N. P., Chaplow, J., Stott, A. W. \& Black, H. I. J. (2006) Translocation of Surface Litter Carbon Into Soil by Collembola. Soil Biology \& Biochemistry, 38, 2655-2664.

Chauvat, M., Titsch, D., Zaytsev, A. S. \& Wolters, V. (2011) Changes in soil faunal assemblages during conversion from pure to mixed forest stands. Forest Ecology and Management, 262, 317-324.

Chauvat, M., Zaitsev, A. S. \& Wolters, V. (2003) Successional changes of Collembola and soil microbiota during forest rotation. Oecologia, 137, 269-276.

Cole, L., Bradford, M. A., Shaw, P. J. A. \& Bardgett, R. D. (2006) The abundance, richness and functional role of soil meso- and macrofauna in temperate grassland - A case study. Applied Soil Ecology, 33, 186-198.

Crotty, F. V., Blackshaw, R. P. \& Murray, P. J. (2011) Tracking the flow of bacterially derived 13C and $15 \mathrm{~N}$ through soil faunal feeding channels. Rapid Communications in Mass Spectrometry, 25, 1503-1513.

Curry, J. P. \& Schmidt, O. (2006) The feeding ecology of earthworms - A review. Pedobiologia, 50, 463-477.

Eason, E. H. (1964) Centipedes of the British Isles. Frederick Warne \& Co Itd., London and New York.

Ehnes, R. B., Rall, B. C. \& Brose, U. (2011) Phylogenetic grouping, curvature and metabolic scaling in terrestrial invertebrates. Ecology Letters, 14, 993-1000.

Eisenhauer, N. (2010) The action of an animal ecosystem engineer: Identification of the main mechanisms of earthworm impacts on soil microarthropods. Pedobiologia, 53, 343-352.

Eisenhauer, N., Straube, D. \& Scheu, S. (2008) Efficiency of two widespread non-destructive extraction methods under dry soil conditions for different ecological earthworm groups. European Journal of Soil Biology, 44, 141-145.

Eissfeller, V., Beyer, F., Valtanen, K., Hertel, D., Maraun, M., Polle, A. \& Scheu, S. (2013) Incorporation of plant carbon and microbial nitrogen into the rhizosphere food web of beech and ash. Soil Biology \& Biochemistry, 62, 76-81.

Erdmann, G., Scheu, S. \& Maraun, M. (2012) Regional factors rather than forest type drive the community structure of soil living oribatid mites (Acari, Oribatida). Experimental and Applied Acarology, 57, 157-169.

Fischer, M., Bossdorf, O., Gockel, S., Hansel, F., Hemp, A., Hessenmoeller, D., Korte, G., Nieschulze, J., Pfeiffer, S., Prati, D., Renner, S., Schoening, I., Schumacher, U., Wells, K., Buscot, F., 
Kalko, E. K. V., Linsenmair, K. E., Schulze, E.-D. \& Weisser, W. W. (2010) Implementing large-scale and long-term functional biodiversity research: The Biodiversity Exploratories. Basic and Applied Ecology, 11, 473-485.

Freude, H., Harde, K. W. \& Lohse, G. A. (1964-2004) Die Käfer Mitteleuropas. Verlag Goecke \& Evers, Krefeld.

Gisin, H. (1984) Collembolenfauna Europas. Museum D'Histoire Naturelle, Geneva.

Graves, S., Piepho, H., Selzer, L. \& Dorai-Raj, S. (2011) multcompView: Visualizations of Paired Comparisons; R package version 0.1-3; http://CRAN.R-project.org/package=multcompView.

Grove, S. J. (2002) Saproxylic insect ecology and the sustainable management of forests. Annual Review of Ecology and Systematics, 33, 1-23.

Gunn, A. (1992) The use of mustard to estimate earthworm populations. Pedobiologia, 36, 65-67.

Hasegawa, M., Okabe, K., Fukuyama, K., Makino, S., Okochi, I., Tanaka, H., Goto, H., Mizoguchi, T. \& Sakata, T. (2013) Community structures of Mesostigmata, Prostigmata and Oribatida in broad-leaved regeneration forests and conifer plantations of various ages. Experimental and Applied Acarology, 59, 391-408.

Hättenschwiler, S., Tiunov, A. V. \& Scheu, S. (2005) Biodiversity and litter decomposition in terrestrial ecosystems. Annual Review of Ecology Evolution and Systematics, 36, 191-218.

Heidemann, K., Scheu, S., Ruess, L. \& Maraun, M. (2011) Molecular detection of nematode predation and scavenging in oribatid mites: Laboratory and field experiments. Soil Biology \& Biochemistry, 43, 2229-2236.

Heimer, S. \& Nentwig, W. (1991) Spinnen Mitteleuropas. Verlag Paul Parey, Berlin and Hamburg.

Högberg, M. N., Högberg, P. \& Myrold, D. D. (2007) Is microbial community composition in boreal forest soils determined by $\mathrm{pH}, \mathrm{C}$-to-N ratio, the trees, or all three? Oecologia, 150, 590-601.

Hopkin, S. P. (1991) A key to the woodlice of Britain and Ireland. Field Studies Council (AIDGAP Project).

Hopkin, S. P. (2007) A key to the Collembola (springtails) of Britain and Ireland. Field Studies Council (AIDGAP Project).

Humphrey, J. W., Hawes, C., Peace, A. J., Ferris-Kaan, R. \& Jukes, M. R. (1999) Relationships between insect diversity and habitat characteristics in plantation forests. Forest Ecology and Management, 113, 11-21.

Joergensen, R. G. \& Scheu, S. (1999) Response of soil microorganisms to the addition of carbon, nitrogen and phosphorus in a forest Rendzina. Soil Biology \& Biochemistry, 31, 859-866.

Jongman, R. H. G., ter Braak, C. J. F. \& van Tongeren, O. F. R. (1995) Data analysis in community and landscape ecology. Cambridge University Press, Cambridge.

Karg, W. (1983) Distribution and importance of predatory mites of the cohort gamasina in relation to their effects on nematodes. Pedobiologia, 25, 419-432.

Karg, W. (1989) Acari (Acarina), Milben. Parasitiformes (Anactinochaeta). Uropodina Kramer, Schildkrötenmilben. Gustav Fischer, Jena.

Karg, W. (1993) Acari (Acarina), Milben. Parasitiformes (Anactinochaeta). Cohors Gamasina Leach. Raubmilben. Gustav Fischer, Jena. 
Kempson, D., Lloyd, M. \& Ghelardi, R. (1963) A new extractor for woodland litter. Pedobiologia, 3, 121.

Klarner, B., Ehnes, R. B., Erdmann, G., Eitzinger, B., Pollierer, M. M., Maraun, M. \& Scheu, S. (in prep.) Trophic shift of soil animal species with forest type as indicated by stable isotope analysis.

Klarner, B., Maraun, M. \& Scheu, S. (2013) Trophic diversity and niche partitioning in a species rich predator guild - Natural variations in stable isotope ratios (C-13/C-12, N-15/N-14) of mesostigmatid mites (Acari, Mesostigmata) from Central European beech forests. Soil Biology \& Biochemistry, 57, 327-333.

Klausnitzer, B. (1978) Ordnung Coleoptera (Larven). Verlag W. Junk, The Hague.

Klausnitzer, B. (1991-2001) Die Käfer Mitteleuropas. Larven Band L1-L6. Spektrum Akademischer Verlag, Heidelberg.

Koehler, H. H. (1999) Predatory Mites (Gamasina, Mesostigmata). Agriculture Ecosystems and Environment, 74, 395-410.

Lauber, C. L., Strickland, M. S., Bradford, M. A. \& Fierer, N. (2008) The influence of soil properties on the structure of bacterial and fungal communities across land-use types. Soil Biology \& Biochemistry, 40, 2407-2415.

Macfadyen, A. (1961) Improved funnel-type extractors for soil arthropods. Journal of Animal Ecology, $30,171-184$.

MCPFE (2007) State of Europe's forest 2007: The report on sustainable forest management in Europe. Ministerial Conference on the Protection of Forests in Europe. Warsaw.

Paillet, Y., Berges, L., Hjalten, J., Odor, P., Avon, C., Bernhardt-Romermann, M., Bijlsma, R. J., De Bruyn, L., Fuhr, M., Grandin, U., Kanka, R., Lundin, L., Luque, S., Magura, T., Matesanz, S., Meszaros, I., Sebastia, M. T., Schmidt, W., Standovar, T., Tothmeresz, B., Uotila, A., Valladares, F., Vellak, K. \& Virtanen, R. (2010) Biodiversity differences between managed and unmanaged forests: Meta-analysis of species richness in Europe. Conservation Biology, 24 , 101-112.

Paterson, E. \& Sim, A. (2000) Effect of nitrogen supply and defoliation on loss of organic compounds from roots of Festuca rubra. Journal of Experimental Botany, 51, 1449-1457.

Pollierer, M. M., Langel, R., Körner, C., Maraun, M. \& Scheu, S. (2007) The underestimated importance of belowground carbon input for forest soil animal food webs. Ecology Letters, 10, 729-736.

Ponge, J. F. (2003) Humus forms in terrestrial ecosystems: a framework to biodiversity. Soil Biology \& Biochemistry, 35, 935-945.

Ponge, J. F., Arpin, P., Sondag, F. \& Delecour, F. (1997) Soil fauna and site assessment in beech stands of the Belgian Ardennes. Canadian Journal of Forest Research-Revue Canadienne De Recherche Forestiere, 27, 2053-2064.

Ponge, J. F., Gillet, S., Dubs, F., Fedoroff, E., Haese, L., Sousa, J. P. \& Lavelle, P. (2003) Collembolan communities as bioindicators of land use intensification. Soil Biology \& Biochemistry, 35, 813-826. 
R Development Core Team (2013) R: A language and environment for statistical computing. R Foundation for Statistical Computing, Vienna, Austria.

Rousk, J., Baath, E., Brookes, P. C., Lauber, C. L., Lozupone, C., Caporaso, J. G., Knight, R. \& Fierer, N. (2010) Soil bacterial and fungal communities across a pH gradient in an arable soil. Isme Journal, 4, 1340-1351.

Rousk, J., Brookes, P. C. \& Baath, E. (2009) Contrasting soil pH effects on fungal and bacterial growth suggest functional redundancy in carbon mineralization. Applied and Environmental Microbiology, 75, 1589-1596.

Ruess, L., Sandbach, P., Cudlin, P., Dighton, J. \& Crossley, A. (1996) Acid deposition in a spruce forest soil: Effects on nematodes, mycorrhizas and fungal biomass. Pedobiologia, 40, 51-66.

Ruf, A., Kuzyakov, Y. \& Lopatovskaya, O. (2006) Carbon fluxes in soil food webs of increasing complexity revealed by $\mathrm{C}-14$ labelling and $\mathrm{C}-13$ natural abundance. Soil Biology \& Biochemistry, 38, 2390-2400.

Schaefer, M. (2010) Brohmer - Fauna von Deutschland. Quelle \& Meyer, Wiebelsheim.

Schaefer, M. \& Schauermann, J. (1990) The soil fauna of beech forests - comparison between a mull and moder soil. Pedobiologia, 34, 299-314.

Scheu, S. (1992) Automated measurement of the respiratory response of soil microcompartments Active microbial biomass in eathworm faeces. Soil Biology \& Biochemistry, 24, 1113-1118.

Scheu, S. (2002) The soil food web: Structure and perspectives. European Journal of Soil Biology, 38, 11-20.

Siira-Pietikainen, A., Pietikainen, J., Fritze, H. \& Haimi, J. (2001) Short-term responses of soil decomposer communities to forest management: clear felling versus alternative forest harvesting methods. Canadian Journal of Forest Research-Revue Canadienne De Recherche Forestiere, 31, 88-99.

Swanson, M. E., Franklin, J. F., Beschta, R. L., Crisafulli, C. M., DellaSala, D. A., Hutto, R. L., Lindenmayer, D. B. \& Swanson, F. J. (2011) The forgotten stage of forest succession: earlysuccessional ecosystems on forest sites. Frontiers in Ecology and the Environment, 9, 117125.

ter Braak, C. J. F. \& Smilauer, P. (2002) CANOCO reference manual and CanoDraw for windows user's guide: software for canonical community ordination (version 4.5). Microcomputer Power Ithaca, New York.

Wardle, D. A. (2002) Communities and Ecosystems - Linking the Aboveground and Belowground Components. Princeton University Press, Princeton and Oxford.

Weigmann, G. (2006) Hornmilben (Oribatida). Verlag Goecke \& Evers, Keltern. 


\section{Chapter 3}

\section{Trophic shift of soil animal species with forest type as indicated by stable isotope analysis}

Bernhard Klarner, Roswitha B. Ehnes, Georgia Erdmann, Bernhard Eitzinger, Melanie M.

Pollierer, Mark Maraun and Stefan Scheu

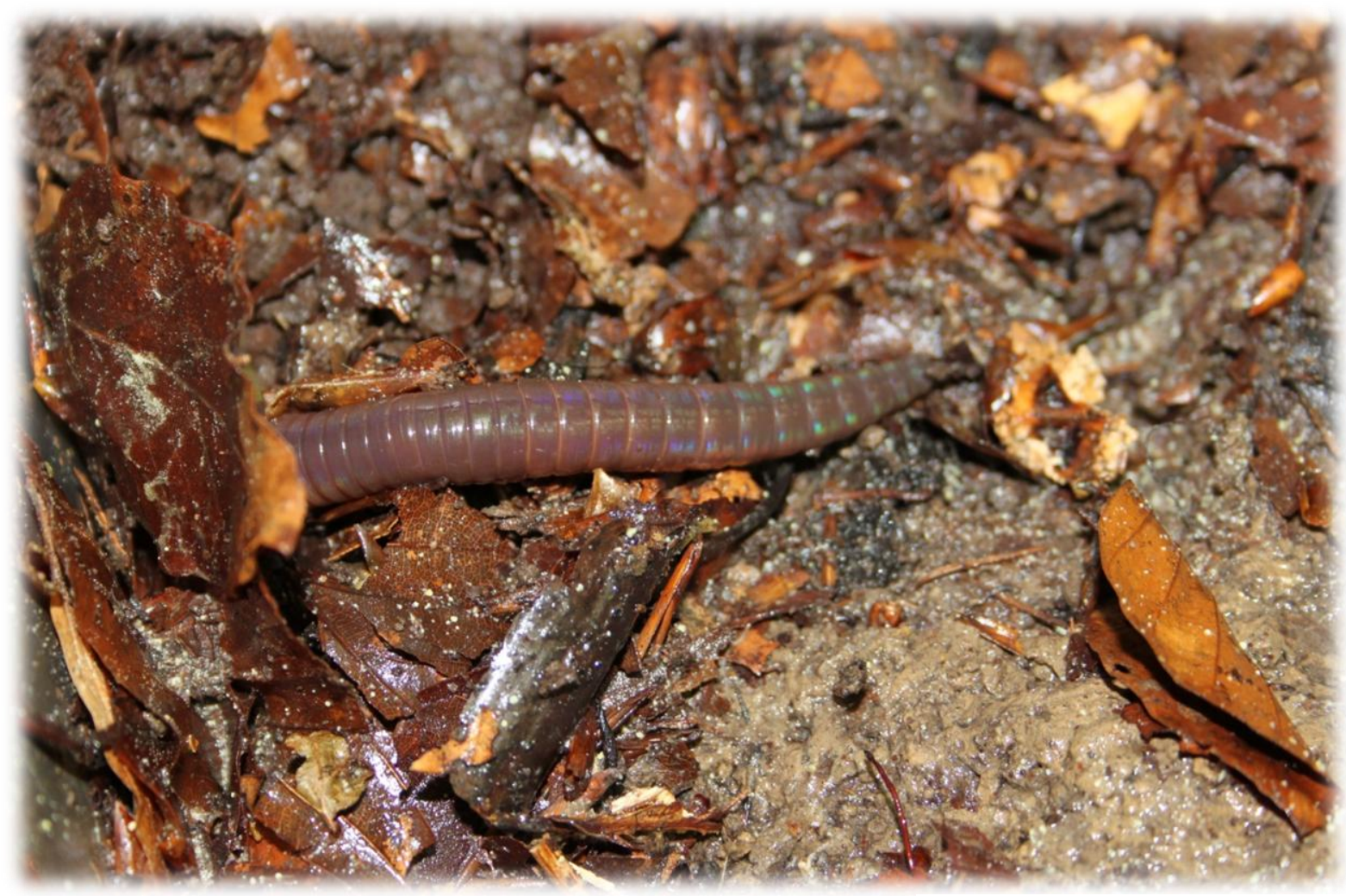

Photo provided by Olga Ferlian

Submitted 


\section{Abstract}

Anthropogenic land use shapes the dynamics and composition of central European forests and changes the quality and availability of resources of the decomposer system. These changes likely alter the structure and functioning of soil animal food webs. Using stable isotope analysis $\left({ }^{13} \mathrm{C},{ }^{15} \mathrm{~N}\right)$ we investigated the trophic position and resource use of soil animal species in each of four forest types (coniferous, young managed beech, old managed beech and unmanaged beech forests) across three regions in Germany. Twenty-eight species of soil invertebrates were analyzed covering three consumer levels and a representative spectrum of feeding types and morphologies. Data on stable isotope signatures of leaf litter, fine roots and soil were included to evaluate to which extent signatures of soil animals vary with those of local resources. Soil animal $\delta^{15} \mathrm{~N}$ and $\delta^{13} \mathrm{C}$ signatures varied with the respective signatures of leaf litter and fine roots. After calibration to leaf litter signatures, soil animal stable isotope signatures of the different beech forests did not differ significantly. However, thick leaf litter layers, such as those in coniferous forests, were associated with low animal stable isotope signatures presumably due to reduced access of decomposer animals to root derived resources suggesting that the decomposer food web is shifted towards leaf litter based energy pathways with the shift affecting all consumer levels.

Key words: soil animal food web, decomposers, resource use, stable isotopes, $\delta^{13} \mathrm{C}, \delta^{15} \mathrm{~N}$, resource quality, leaf litter, habitat structure 


\section{Introduction}

Soil animals are important drivers of decomposition processes, nutrient cycling and plant growth (Cragg and Bardgett 2001, Wardle 2002, Hättenschwiler et al. 2005). Belowground food webs acquire a major fraction of their energy from detritus (Moore and DeRuiter 1991) and therefore are viewed as decomposer or brown food webs. In forests most species either directly consume dead organic matter, in particular leaf litter, feed on microbial decomposers or prey on primary and secondary decomposers thereby forming part of the decomposer food web. Therefore, its community composition is closely linked to qualitative properties and turnover rates of organic matter (Berg and Bengtsson 2007). However, little is known on variations in the structure of decomposer food webs with forest management and the associated changes in ecosystem services they provide.

In Central Europe virtually any forest is managed and thereby growth dynamics and overall structure of forests are altered (Bengtsson et al. 2000). Forest management may result in reduced aboveground biodiversity e.g., due to reducing the number of species which depend on canopy closure, availability of deadwood and presence of old trees (Paillet et al. 2010). The impact of forest management on belowground communities is less well understood. Land use effects vary with forest type, the intensity of associated disturbances and also the organism group in focus (Siira-Pietikainen et al. 2001, Chauvat et al. 2003, 2011), reflecting that soil food webs are structurally complex with high rates of omnivory and intra-guild predation (Digel et al. this issue).

Soil food webs are generally assumed to be buffered against environmental changes. This is mainly due to the fact that soil animal species often are able to adjust their diet in an opportunistic way (Siira-Pietikainen et al. 2001, Scheu 2002). Due to high diversity many species in soil animal food webs may be functionally redundant (Cole et al. 2006). However, there is evidence that changes at the base of the decomposer food web may propagate to higher trophic levels thereby affecting trophic interactions. It has been suggested that energy flow via the bacterial energy pathway is less affected by disturbances than that through the fungal energy pathway (Wardle 2002, Hedlund et al. 2004). Presumably, this is due to faster energy processing by bacteria and the associated food chain, and this may render the bacterial based food web less responsive to forest management. In fact, it has been shown that disturbances associated with tree harvesting affect saprotrophic fungi but not microbial biomass in total including bacteria (Moore-Kucera and Dick 2008, Hynes and Germida 2012).

Stable isotope analysis is an established and valuable tool to track the pathway of carbon and nitrogen from different food sources into the body tissue of animal consumers and increasingly used to unveil trophic interactions in soil food webs (Tiunov 2007). Consumers 
usually are more enriched in the heavy nitrogen isotope $\left({ }^{15} \mathrm{~N}\right)$ than their dietary resource due to fractionation processes; natural variations in ${ }^{15} \mathrm{~N} /{ }^{14} \mathrm{~N}$ ratios therefore allow estimating the trophic level of species (DeNiro and Epstein 1981, Peterson and Fry 1987, Scheu and Falca 2000). Generally, trophic level enrichment averages 3.4\% (Post 2002, Martinez del Rio et al. 2009), and this also applies to soil invertebrates including predators (Scheu and Falca 2000, Ponsard and Arditi 2000, Oelbermann and Scheu 2010). However, fractionation has also been documented to vary and this appears to be more pronounced in species of basal trophic levels such as detritivores (Vanderklift and Ponsard 2003). In contrast to ${ }^{15} \mathrm{~N}$, trophic level fractionation of ${ }^{13} \mathrm{C}$ is low averaging about $0.4 \%$ (Post 2002). Due to this low fractionation ${ }^{13} \mathrm{C}$ signatures of consumers resemble those of food resources (DeNiro and Epstein 1978, Peterson and Fry 1987, Post 2002). The combined analysis of natural variations in ${ }^{13} \mathrm{C} /{ }^{12} \mathrm{C}$ and ${ }^{15} \mathrm{~N} /{ }^{14} \mathrm{~N}$ ratios therefore provides insight into the dietary niche of species and its spatial and temporal variability (Bearhop et al. 2004).

The present study investigated natural variations in ${ }^{13} \mathrm{C} /{ }^{12} \mathrm{C}$ and ${ }^{15} \mathrm{~N} /{ }^{14} \mathrm{~N}$ ratios of 28 species of soil invertebrates in each of four forest types representing different intensities of forest management and habitat modification. Species were selected to include a wide range of taxonomic and trophic groups common in Central European forests. Species of different trophic groups - as indicated by natural variations in ${ }^{15} \mathrm{~N} /{ }^{14} \mathrm{~N}$ ratios - were analyzed to uncover changes in the trophic structure of soil animal communities with forest type. Stable isotope signatures of leaf litter, fine roots and soil were included to evaluate if stable isotope signatures of soil animals are affected by those of basal resources. Furthermore, habitat characteristics, such as leaf litter deposition, C-to-N ratio of leaf litter and microbial activity, were included to identify factors responsible for variations in stable isotope signatures of soil animals.

We hypothesized (1) ${ }^{15} \mathrm{~N} /{ }^{14} \mathrm{~N}$ ratios of soil animal species to vary little with forest type reflecting the stability of forest soil food webs against changes in habitat characteristics, (2) ${ }^{13} \mathrm{C} /{ }^{12} \mathrm{C}$ ratios of soil animal species to vary due to differences in the availability and quality of litter resources in the different forest types, and (3) differences in ${ }^{13} \mathrm{C} /{ }^{12} \mathrm{C}$ ratios of soil animal species between forest types to decline with higher trophic level due to omnivory and generalistic feeding. 


\section{Materials and methods}

\subsection{Study sites}

Four replicates of four forest types were sampled in each of three regions of Germany, i.e. Swabian Alb, Hainich-Dün (Hainich) and Schorfheide-Chorin (Schorfheide). The selected forest types included coniferous forests, age class stands of young beech (Fagus sylvatica) with an approximate age of 30 years (young managed beech), mature age class stands of beech with an age of approximately 70 years (old managed beech) and mature beech stands which have been left unmanaged for at least 60 years (unmanaged beech). Coniferous forests consisted of spruce (Picea abies) in the Swabian Alb and Hainich, and pine (Pinus sylvestris) in the Schorfheide. Coniferous forests represent the most intensively managed forest type as they have been planted and replace naturally occurring beech dominated stands. In respect to management intensity they are followed by young managed beech, old managed beech and unmanaged beech.

The study sites form part of the "Biodiversity Exploratories", a large integrative biodiversity research project (www.biodiversity-exploraties.de). The three regions (Exploratories) differ in geology and altitude; the Schorfheide is located in a glacial landscape in the north-east of Germany (3 - $140 \mathrm{~m}$ a.s.l.), the Hainich is located in the moderately hilly landscape of Central Germany (285 - $550 \mathrm{~m}$ a.s.I.) and the Swabian Alb in the low mountain range of southwestern Germany (480 - $860 \mathrm{~m}$ ). Swabian Alb and Hainich both feature calcareous bedrock and soils with high clay content, whereas the soils in the Schorfheide range from sandy loam to almost pure sand (Fischer et al. 2010).

\subsection{Sampling, extraction and determination of soil animals}

Samples were taken in spring 2008. Soil mesofauna (Collembola, Oribatida and Mesostigmata) was extracted from two small soil cores $(5 \mathrm{~cm} \varnothing)$ taken at each study site. For soil macrofauna (Araneae, Chilopoda, Diplopoda, Insecta and Isopoda) large soil cores were taken $(20 \mathrm{~cm} \varnothing)$, two in coniferous forests, young managed beech and old managed beech stands, and four in unmanaged beech stands. The litter layer and upper $5 \mathrm{~cm}$ of the soil cores were extracted separately by heat (Kempson et al. 1963). Lumbricidae were extracted from each site using mustard solution (Eisenhauer et al. 2008). The solution was prepared by mixing $100 \mathrm{mg}$ of mustard powder (Semen Sinapis plv., Caesar \& Loretz GmbH, Hilden, Germany) with 10 I of water. The mixture was left to steep over night. At each plot an area of $50 \times 50 \mathrm{~cm}$ was confined using a steel frame, leaf litter was removed and hand sorted for Lumbricidae. Then, 5 I of mustard solution were applied to the soil surface; Lumbricidae 
were collected during the following $15 \mathrm{~min}$, then, another $5 \mathrm{I}$ of solution was applied and Lumbricidae were collected for another $15 \mathrm{~min}$. Animals were determined to species level and stored in ethanol until further processing. The amount of leaf litter was measured by weighing the macrofauna litter samples after animal extraction.

\subsection{Preparation of samples}

Soil animals, litter and soil material were dried at $60^{\circ} \mathrm{C}$ for $24 \mathrm{~h}$ prior to stable isotope analysis. Large animals were homogenized with a mortar and pestle before measurement. For smaller animals (Acari and Collembola) between 5 and 100 individuals were pooled. If possible, for each species replicates from each of the plots studied were analyzed. In Lumbricidae up to three specimens per plot were analyzed. A complete list of species including the respective number of samples analyzed is given in the supplementary material (Table A1). Before measurement soil and litter material as well as fine roots from macrofauna soil cores were dried and ground with a ball mill (Retsch Mixer Mill MM200, Haan, Germany).

\subsection{Stable isotope and C-to-N analyses}

Stable isotope and $\mathrm{C}$-to- $\mathrm{N}$ ratios of animals, soil, fine roots and leaf litter were determined using a coupled system of an elemental analyzer (NA 1500, Carlo Erba, Milan, Italy) and a mass spectrometer (MAT 251, Finnigan, Bremen, Germany) (Reineking et al. 1993). Isotopic signatures were expressed using the $\delta$ notation with $\delta X(\%)=\left(R_{\text {sample }}-R_{\text {standard }}\right) / R_{\text {standard }} X$ 1000 , with $X$ representing the target isotope and $R$ the ratio of heavy to light isotope $\left({ }^{13} \mathrm{C} /{ }^{12} \mathrm{C}\right.$ and ${ }^{15} \mathrm{~N} /{ }^{14} \mathrm{~N}$, respectively). Nitrogen in atmospheric air and Vienna PD Belemnite served as standard for $\delta^{15} \mathrm{~N}$ and $\delta^{13} \mathrm{C}$ analyses, respectively.

\subsection{Analysis of microbial biomass}

Microbial biomass in litter material was assessed by measuring the maximum initial respiratory response (MIRR; $\mathrm{mg} \mathrm{O}_{2} \mathrm{~g}^{-1} \mathrm{~h}^{-1}$ ) after glucose addition (SIR method; Anderson and Domsch 1980, Beck et al. 1997) in an automated $\mathrm{O}_{2}$ microcompensation apparatus (Scheu 1992). Glucose (80 $\mathrm{mg} \mathrm{g}^{-1}$ dry weight) was added as an aqueous solution to approximately 1 $\mathrm{g}$ of leaf litter material adjusting the water content to $80-90 \%$ of the water holding capacity (Joergensen and Scheu 1999). 


\subsection{Data analysis}

Statistical analyses were performed using R 3.0.1 (R Development Core Team 2013). Data were inspected for heteroscedasticity using Levene's test and log transformed if necessary to improve homogeneity of variances. Mean values and standard deviations in text and figures are based on non-transformed values.

Stable isotope values of litter, fine roots and soil were analyzed by two factorial analysis of variance with the factors region and forest type. Differences between means were inspected using Tukey's honestly significant difference test. Pearson correlations were used to analyze interrelationships between stable isotope values of leaf litter, fine roots and soil.

Stable isotope values of animals are given as difference to the respective signatures of leaf litter of the study site the animals were sampled, i.e. by calculating $\Delta^{13} \mathrm{C}$ and $\Delta^{15} \mathrm{~N}$ values. Each species was assigned to a consumer level using the respective mean $\Delta^{15} \mathrm{~N}$ value over all sites. For the basal (first) consumer level a mean enrichment of $0.5 \%$ relative to the basal resource (leaf litter) was used (Vanderklift and Ponsard 2003); consumers generally were assumed to span $3.4 \%$ (Post 2002). Linear regressions between soil animal $\delta^{13} \mathrm{C}$ and $\delta^{15} \mathrm{~N}$ signatures of individual trophic levels and the respective signatures of leaf litter, fine root and soil of the respective sampling sites were used to investigate if soil animal signatures depend on the signatures of local resources.

Variations in the trophic position of consumers, as indicated by $\Delta^{13} \mathrm{C}$ and $\Delta^{15} \mathrm{~N}$ values, with trophic level and forest type were inspected by general linear models with the factors trophic level and forest type. Linear regressions between $\delta^{13} \mathrm{C}$ and $\delta^{15} \mathrm{~N}$ signatures of soil animal species of individual trophic levels and the amount of leaf litter in the litter layer, litter $\mathrm{C}$-to-N ratios and microbial biomass of leaf litter were used to inspect if soil animal signatures are affected by the availability and quality of basal resources.

\section{Results}

\subsection{Variations in stable isotope signatures of soil, leaf litter and fine roots}

Soil $\delta^{13} \mathrm{C}$ signatures did not differ significantly between regions and forest types. $\delta^{13} \mathrm{C}$ signatures of leaf litter were generally higher in coniferous forests compared to beech forests (Supplementary material Fig. A1, Table A1, A2). Fine root $\delta^{13} \mathrm{C}$ signatures also differed significantly between forest types, however, differences varied between regions and were most pronounced between coniferous and beech stands of the Swabian Alb and Hainich (Fig. A2, Table A1, A2). 
$\delta^{15} \mathrm{~N}$ signatures of the basal resources investigated differed significantly between regions, whereas the effect of forest type generally was not significant (Table A1). Soil $\delta^{15} \mathrm{~N}$ signatures decreased in the order Swabian Alb, Hainich and Schorfheide (Fig. A3c, Table A2). $\delta^{15} \mathrm{~N}$ signatures of leaf litter and fine roots were higher in the Swabian Alb and Hainich as compared to the Schorfheide (Figs. A3a, b, Table A2).

Pearson correlations indicated that $\delta^{13} \mathrm{C}$ signatures of leaf litter and fine roots correlated positively $\left(r=0.63, p<0.001\right.$ ) (Fig. A4a). Neither leaf litter nor fine root $\delta^{13} \mathrm{C}$ signatures correlated significantly with soil $\delta^{13} \mathrm{C}$ signatures $(r=0.24, p=0.09$ and $r=0.20, p=0.18$, respectively) (Figs. A4b, c). Similar to $\delta^{13} \mathrm{C}$, signatures of $\delta^{15} \mathrm{~N}$ of leaf litter correlated positively with those of fine roots $(r=0.82, p<0.001)$ (Fig. A5a), but also with those of soil $(r$ $=0.84, p<0.001)$ (Fig. A5b). Also, $\delta^{15} \mathrm{~N}$ signatures of fine roots correlated positively with those of soil $(r=0.70, p<0.001)$ (Fig. A5c).

\subsection{Stable isotope signatures of soil animals as affected by resource stable isotope signatures}

$\Delta^{15} \mathrm{~N}$ values of soil animals indicated that the species investigated spanned three trophic levels, from first to third level consumers (Fig. A6); for a complete list of species and their respective trophic level see Table $A 3$. Linear regressions indicated that $\delta^{13} \mathrm{C}$ signatures of second and third level consumers increased significantly with $\delta^{13} \mathrm{C}$ signatures of leaf litter and fine roots; however, $r^{2}$ values were low (Table 1, Fig. A7).

$\delta^{15} \mathrm{~N}$ signatures of first, second and third level consumers increased significantly with $\delta^{15} \mathrm{~N}$ signatures of leaf litter, fine roots and soil of the respective sampling location (Table 1, Fig. A8); $r^{2}$ values indicated that leaf litter $\delta^{15} \mathrm{~N}$ signatures explained the largest fraction of $\delta^{15} \mathrm{~N}$ signatures of soil animals in each of the three trophic levels. 
Table 1. Regressions between stable isotope signatures $\left(\delta^{13} \mathrm{C}\right.$ and $\left.\delta^{15} \mathrm{~N}\right)$ of leaf litter, fine roots and soil and the respective signatures of soil animals of different trophic levels (first, second and third level consumers); significant results are marked in bold, asterisks indicate significance level $\left({ }^{*} p<\right.$ $\left.0.05,{ }^{* *} p<0.01,{ }^{* * *} p<0.001\right)$.

\begin{tabular}{|c|c|c|c|c|c|}
\hline \multirow[b]{2}{*}{ Resource } & \multirow[b]{2}{*}{ Trophic level } & \multicolumn{2}{|l|}{$\delta^{13} \mathrm{C}$} & \multicolumn{2}{|l|}{$\delta^{15} \mathrm{~N}$} \\
\hline & & $r^{2}$ & F-value & $r^{2}$ & F-value \\
\hline \multirow{3}{*}{ Leaf litter } & $\begin{array}{l}1^{\text {st }} \text { level } \\
\text { consumers } \\
2^{\text {nd }} \text { level }\end{array}$ & 0.02 & $F_{1,115}=3.38$ & 0.43 & $F_{1,115}=90.17^{\star \star \star}$ \\
\hline & $\begin{array}{l}\text { consumers } \\
3^{\text {rd }} \text { level }\end{array}$ & 0.02 & $F_{1,438}=11.61^{\star \star \star}$ & 0.36 & $F_{1,438}=244.70^{\star \star \star}$ \\
\hline & consumers & 0.02 & $F_{1,202}=6.16^{\star}$ & 0.44 & $F_{1,202}=157.4^{\star \star \star}$ \\
\hline \multirow{3}{*}{$\begin{array}{l}\text { Fine } \\
\text { roots }\end{array}$} & $\begin{array}{l}1^{\text {st }} \text { level } \\
\text { consumers } \\
2^{\text {nd }} \text { level }\end{array}$ & 0.00 & $F_{1,115}=0.11$ & 0.41 & $F_{1,115}=82.62 * \star *$ \\
\hline & $\begin{array}{l}\text { consumers } \\
3^{\text {rd }} \text { level }\end{array}$ & 0.04 & $F_{1,438}=17.09^{\star \star \star}$ & 0.30 & $F_{1,438}=190.00^{\star \star \star}$ \\
\hline & consumers & 0.06 & $F_{1,202}=13.77^{\star \star \star}$ & 0.37 & $F_{1,202}=122.5^{\star \star \star}$ \\
\hline \multirow{3}{*}{ Soil } & $\begin{array}{l}1^{\text {st }} \text { level } \\
\text { consumers } \\
2^{\text {nd }} \text { level }\end{array}$ & 0.01 & $F_{1,115}=2.24$ & 0.16 & $F_{1,115}=23.06$ *** \\
\hline & $\begin{array}{l}\text { consumers } \\
3^{\text {rd }} \text { level }\end{array}$ & 0.00 & $F_{1,438}=0.59$ & 0.23 & $F_{1,438}=133.5^{\star \star \star}$ \\
\hline & consumers & 0.01 & $F_{1,202}=2.86$ & 0.38 & $F_{1,202}=126.9 * \star \star$ \\
\hline
\end{tabular}

\subsection{Stable isotope enrichment of soil animals in different forest types}

$\Delta^{13} \mathrm{C}$ values of soil animal species differed significantly between trophic levels $\left(\mathrm{F}_{2,747}=\right.$ $26.84, p<0.001$ ), with values increasing from $4.52 \pm 0.92 \%$ in first level consumers to $4.90 \pm$ $1.22 \%$ in second level consumers and $5.30 \pm 0.99 \%$ in third level consumers (Fig. 1a). Further, $\Delta^{13} \mathrm{C}$ of soil animal species differed significantly between forest types $\left(F_{3 ; 747}=41.84\right.$, $p<0.001)$, with lower values in coniferous forests $(4.17 \pm 1.10 \%)$, compared to beech forests $(5.14 \pm 1.11 \%$, $5.15 \pm 1.00 \%$ and $5.21 \pm 1.09 \%$ for young managed, old managed and unmanaged beech forests, respectively; Fig. 1b). 


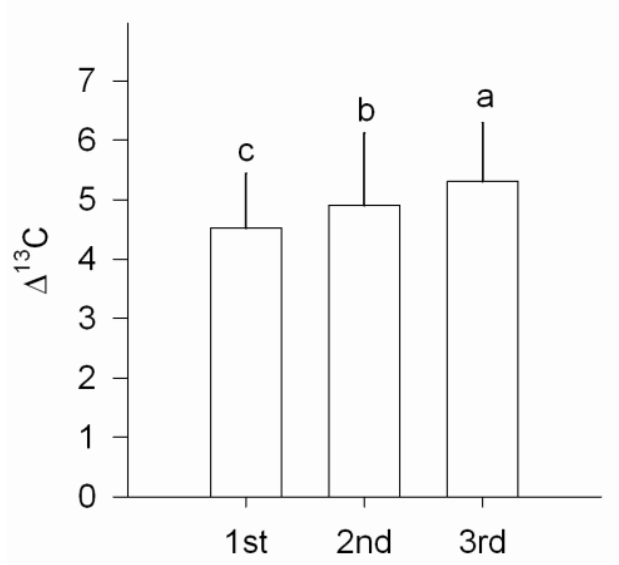

a)

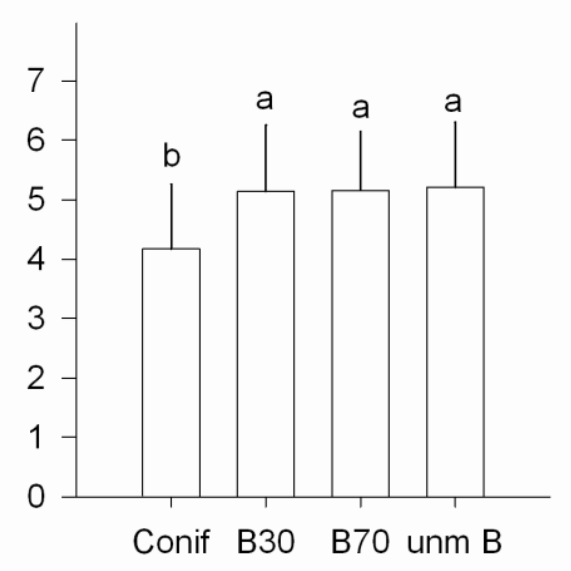

b)

Fig 1. $\Delta^{13} \mathrm{C}$ values (means $\pm \mathrm{SD}$ ) of soil animals from (a) different trophic levels (first, second and third level consumers) and (b) of soil animals sampled of different forest types (Conif $=$ coniferous forest, $\mathrm{B} 30=$ young managed beech, B70 = old managed beech, unm B = unmanaged beech); different letters indicate significant differences between means $(p<0.05$, Tukey's HSD).

Similarly, $\Delta^{15} \mathrm{~N}$ values of soil animal species increased with trophic level and differed between forest types. $\Delta^{15} \mathrm{~N}$ values were significantly lower in coniferous forests compared to each of the beech forest types studied, however, differences were more pronounced in first and third level consumers than in second level consumers (significant trophic level $\times$ forest type interaction, $\left.F_{6,747}=3.36, p=0.003\right)$. In first and third level consumers $\Delta^{15} \mathrm{~N}$ values increased from $0.42 \pm 1.35 \%$ and $5.85 \pm 1.34 \%$ in coniferous forests to an average of $1.94 \pm$ $0.87 \%$ and $7.42 \pm 1.09 \%$ in young managed, old managed and unmanaged beech, respectively (Fig. 2; for statistical analysis of stable isotope values of individual species see Table A4). Respective values of second level consumers were $3.46 \pm 1.34 \%$ ond $4.09 \pm$ $1.45 \%$. 


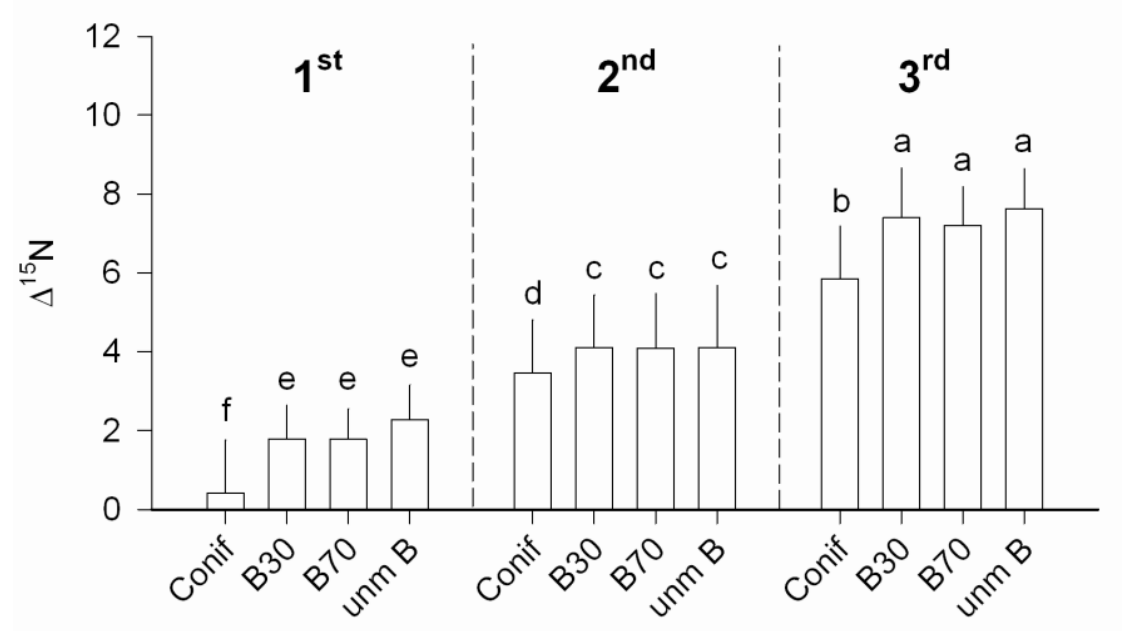

Fig. 2. $\Delta^{15} \mathrm{~N}$ values (means $\pm \mathrm{SD}$ ) of soil animals from different trophic levels (first, second and third level consumers) of the four forest types studied; for legend see Fig. 1; different letters indicate significant differences between means ( $p<0.05$, Tukey's HSD).

\subsection{Variations in stable isotope signatures of soil animals with resource availability and quality}

Linear regressions indicated that $\Delta^{13} \mathrm{C}$ values of first level consumers decreased significantly with increasing amount of leaf litter in the litter layer, but were not significantly affected by litter $\mathrm{C}$-to- $\mathrm{N}$ ratio and litter microbial biomass (Figs. 3a-c, Table 2). $\Delta^{15} \mathrm{~N}$ values of first level consumers decreased with the amount of leaf litter in the litter layer and increased with litter $\mathrm{C}$-to- $\mathrm{N}$ ratio but were not affected by litter microbial biomass (Figs. 4a-c, Table 2). However, with the exception of the negative relationship between $\Delta^{13} \mathrm{C}$ and $\Delta^{15} \mathrm{~N}$ values of first level consumers and the amount of leaf litter in the litter layer, $\mathrm{r}^{2}$ values were below 0.1 indicating that the individual factors explained only a small fraction of the variation in stable isotope signatures of animal species.

In second level consumers $\Delta^{13} \mathrm{C}$ values decreased significantly with the amount of leaf litter in the litter layer and litter $\mathrm{C}$-to-N ratio, but increased with litter microbial biomass (Figs. $3 \mathrm{~d}-\mathrm{f}) . \Delta^{15} \mathrm{~N}$ values of second level consumers decreased significantly with the amount of leaf litter in the litter layer, but were not affected by litter $\mathrm{C}$-to- $\mathrm{N}$ ratio and litter microbial biomass (Figs. 4d-f, Table 2). Again, $r^{2}$ values were below 0.1 indicating that individual factors explained little of the variation in stable isotope signatures of animal species.

In third level consumers $\Delta^{13} \mathrm{C}$ values did not vary significantly with the amount of leaf litter in the litter layer, decreased with litter $\mathrm{C}$-to- $\mathrm{N}$ ratio and increased significantly with litter microbial biomass (Figs. $3 g-i) . \Delta^{15} \mathrm{~N}$ values of third level consumers decreased significantly with the amount of leaf litter in the litter layer and litter $\mathrm{C}$-to- $\mathrm{N}$ ratio but increased significantly 
with litter microbial biomass (Figs. 4g-i, Table 2). However, with the exception of the decrease in $\Delta^{13} \mathrm{C}$ values with leaf litter $\mathrm{C}$-to- $\mathrm{N}$ ratio, $r^{2}$ values below 0.1 indicating that individual factors explained little of the variations in stable isotope signatures of animal species.
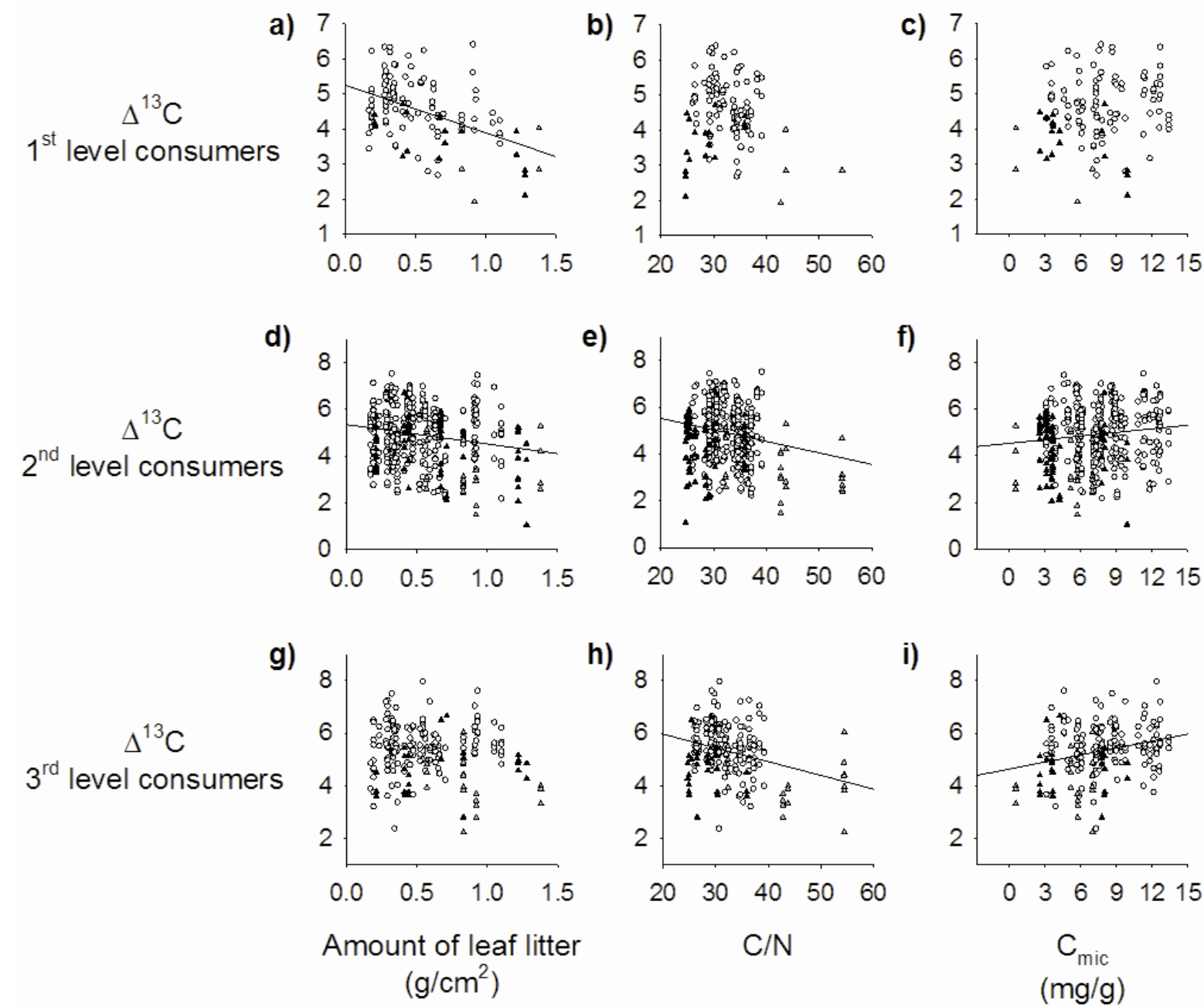

Fig. 3. Relationship between properties of the leaf litter layer [amount of litter, C-to-N ratio, microbial biomass $\left.\left(C_{\text {mic }}\right)\right]$ and $\Delta^{13} \mathrm{C}$ values of first level consumers $(\mathrm{a}-\mathrm{C})$, second level consumers $(\mathrm{d}-\mathrm{f})$ and third level consumers $(\mathrm{g}-\mathrm{i})$; for $\mathrm{r}^{2}$ - and $\mathrm{p}$-values see Table 2 ; open dots $=$ beech, black triangles $=$ spruce, grey triangles $=$ pine. 

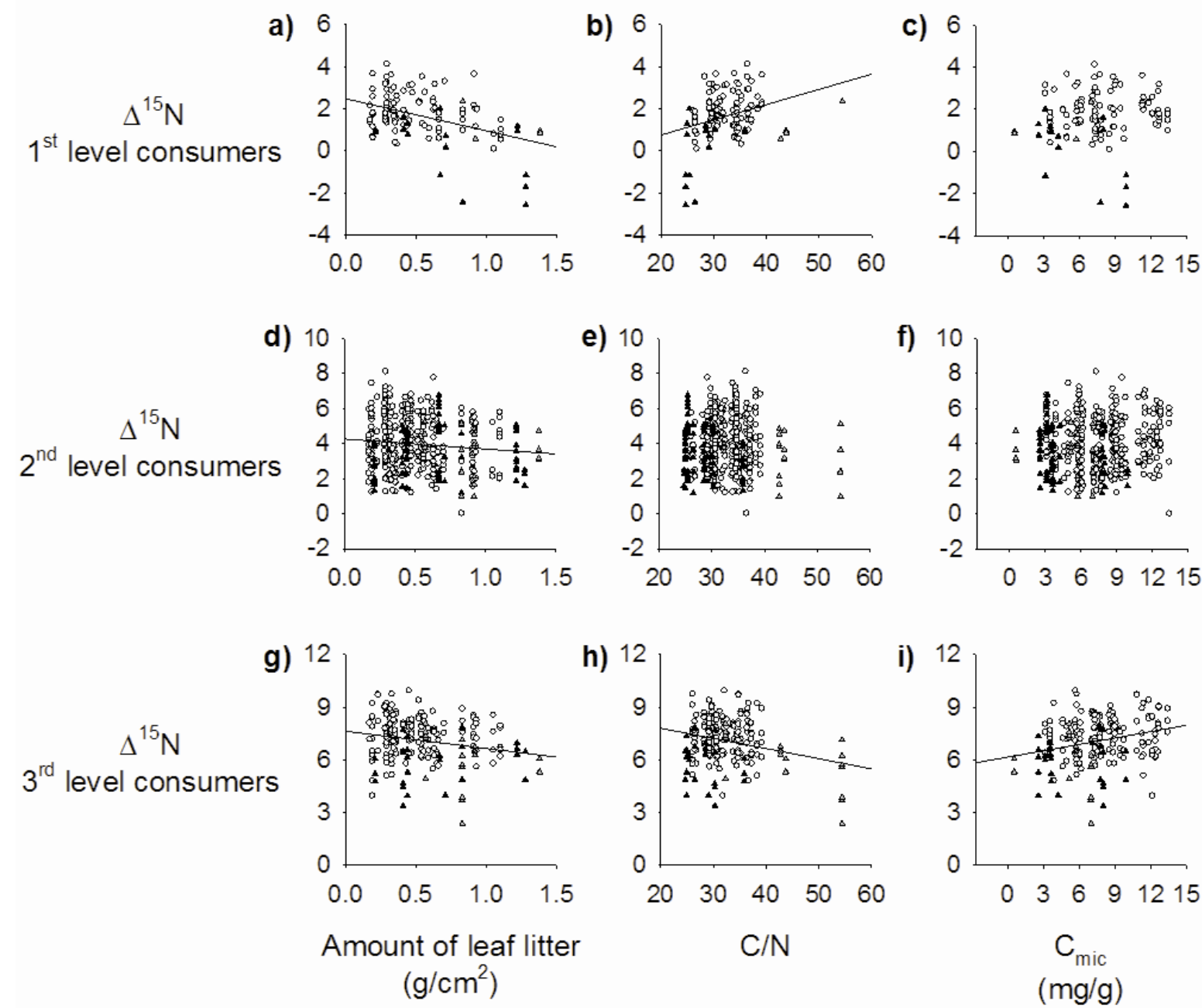

Fig. 4. Relationship between properties of the leaf litter layer [amount of litter, C-to-N ratio, microbial biomass $\left(\mathrm{C}_{\text {mic }}\right)$ ] and $\Delta^{15} \mathrm{~N}$ values of first level consumers $(\mathrm{a}-\mathrm{c})$, second level consumers $(\mathrm{d}-\mathrm{f})$ and third level consumers $\left(\mathrm{g}\right.$-i); for $\mathrm{r}^{2}$ - and $\mathrm{p}$-values see Table 2; open dots = beech, black triangles $=$ spruce, grey triangles $=$ pine.

Table 2. Regressions between properties of the leaf litter layer [amount of litter, $\mathrm{C} / \mathrm{N}$ ratio, microbial biomass $\left(\mathrm{C}_{\text {mic }}\right)$ ] and stable isotope values $\left(\Delta^{13} \mathrm{C}\right.$ and $\left.\Delta^{15} \mathrm{~N}\right)$ of soil animals of different trophic levels (first, second and third level consumers, respectively); significant results are marked in bold, asterisks indicate significance level $\left({ }^{*} p<0.05,{ }^{* *} p<0.01,{ }^{* \star *} p<0.001\right)$.

\begin{tabular}{|c|c|c|c|c|c|}
\hline & \multirow[b]{2}{*}{ Trophic level } & \multicolumn{2}{|l|}{$\Delta^{13} \mathrm{C}$} & \multicolumn{2}{|c|}{$\Delta{ }^{15} \mathrm{~N}$} \\
\hline & & $r^{2}$ & F-value & $r^{2}$ & F-value \\
\hline \multirow{3}{*}{ Amount of leaf litter } & $1^{\text {st }}$ level consumers & 0.21 & $F_{1,115}=31.19^{\star \star \star}$ & 0.17 & $F_{1,115}=24.84^{\star * *}$ \\
\hline & $2^{\text {nd }}$ level consumers & 0.03 & $F_{1,438}=16.69^{\star \star \star}$ & 0.01 & $F_{1,438}=5.37^{\star}$ \\
\hline & $3^{\text {rd }}$ level consumers & 0.01 & $F_{1,202}=2.20$ & 0.05 & $F_{1,202}=9.91^{\star \star}$ \\
\hline \multirow{3}{*}{ Litter C-to-N ratio } & $1^{\text {st }}$ level consumers & 0.01 & $F_{1,115}=2.23$ & 0.08 & $F_{1,115}=11.0^{\star \star}$ \\
\hline & $2^{\text {nd }}$ level consumers & 0.04 & $F_{1,438}=17.1^{\star \star \star}$ & 0.00 & $F_{1,438}=1.37$ \\
\hline & $3^{\text {rd }}$ level consumers & 0.10 & $F_{1,202}=23.46^{\star \star \star}$ & 0.07 & $F_{1,202}=15.54^{\star \star \star}$ \\
\hline \multirow{3}{*}{ Litter $\mathrm{C}_{\text {mic }}$} & $1^{\text {st }}$ level consumers & 0.01 & $F_{1,115}=2.41$ & 0.01 & $F_{1,115}=1.79$ \\
\hline & $2^{\text {nd }}$ level consumers & 0.01 & $F_{1,438}=6.61^{*}$ & 0.01 & $F_{1,438}=3.39$ \\
\hline & $3^{\text {rd }}$ level consumers & 0.06 & $F_{1,202}=14.57^{\star \star \star}$ & 0.07 & $F_{1,202}=15.29^{\star \star \star}$ \\
\hline
\end{tabular}




\section{Discussion}

\subsection{Calibrating soil animal stable isotope signatures}

Stable isotope signatures of resources of the decomposer system varied with study region and/or forest type. Variations in $\delta^{13} \mathrm{C}$ signatures of leaf litter and fine roots between coniferous and beech trees presumably are related to differences in physiological traits, such as water use efficiency or foliar seasonality (Chevillat et al. 2005, Kuptz et al. 2011, Wang et al. 2013). $\delta^{15} \mathrm{~N}$ signatures of resources did not vary with forest type, however, higher signatures in the Swabian Alb and Hainich as compared to the Schorfheide reflect regional differences in the overall nitrogen balance, presumably related to factors such as nitrogen depositions, precipitation and mean temperature (Boeckx et al. 2005). Regression analyses indicated that local variations in stable isotope signatures of resources significantly influenced stable isotope signatures of soil animals, underlining that calibration is needed for comparing signatures of soil animal species from different localities and forest types. $\delta^{15} \mathrm{~N}$ signatures of leaf litter and fine roots explained substantial fractions of the variation in $\delta^{15} \mathrm{~N}$ signatures of soil animal species of each of the three trophic levels. Relationships between $\delta^{13} \mathrm{C}$ signatures of resources and soil animal species were weak; the incorporation of calcium carbonate into the cuticle might have obscured the relationship (Norton and Behan-Pelletier 1991, Maraun et al. 2011). Since $\delta^{13} \mathrm{C}$ as well as $\delta^{15} \mathrm{~N}$ signatures of leaf litter and fine roots were closely interrelated both may be used for calibrating signatures of animal species. As leaf litter material is more accessible and stable isotope signatures of leaf litter are more frequently reported than those of fine roots we calibrated stable isotope signatures of soil animal species to the signatures of leaf litter.

\subsection{Soil animal nutrition as affected by forest type}

Overall, results of the present study suggest that the trophic structure of soil animal food webs varies little with forest type. Stable isotope signatures of animal species from each consumer level calibrated to those of leaf litter $\left(\Delta^{13} \mathrm{C}\right.$ and $\left.\Delta^{15} \mathrm{~N}\right)$ were similar for each of the beech forest types studied. This suggests that trophic niches of soil animal species vary little with age structure and management of forest stands. Using stable isotope analysis niche conservancy has been shown previously for oribatid mites of different beech forests (Schneider et al. 2004).

In contrast to the different types of beech forests, the results indicate that trophic niches and the utilization of resources by soil animal species vary significantly between beech and coniferous forests. Soil animals were generally more enriched in beech as compared to 
coniferous forests. Notably, the differences between beech and coniferous forests were consistent across different species and consumer levels, and results of Ferlian and Scheu (this issue) suggest that this is also true for species interactions such as predation. The results therefore suggest structural differences at the base of the food web of deciduous and coniferous forests. As detailed below these differences are likely to be related to differences in the relative importance of litter and root derived resources in beech as compared to coniferous forests.

It is increasingly realized that soil animal food webs essentially rely on root derived resources rather than on leaf litter only (Ruf et al. 2006, Pollierer et al. 2007, Eissfeller et al. 2013). Typically, $\delta^{13} \mathrm{C}$ values of soil animal species are enriched by $3-5 \delta$ units as compared to $\delta^{13} \mathrm{C}$ values of leaf litter indicating that basal resources comprise predominantly ${ }^{13} \mathrm{C}$ enriched litter compounds such as glucose and other low molecular weight molecules (Pollierer et al. 2009). Stable isotope labeling and complementary techniques such as fatty acid analysis provided further evidence that root derived resources are of significant importance for fueling soil food webs (Pollierer et al. 2007, Eissfeller et al. 2013). Presumably, a large fraction of carbon and nitrogen in root exudates is passed on to soil animals via bacteria and mycorrhizal fungi and is channeled to higher tropic levels (Ruf et al. 2006, Crotty et al. 2011, Pollierer et al. 2012, Ferlian and Scheu this issue). Unfortunately, data on stable isotope signatures of root exudates of beech, spruce or pine forests are not available. However, $\delta^{13} \mathrm{C}$ signatures of phloem sap of beech, forming the basis of root exudates, are in the range of $-26 \%$ (Gessler et al. 2004) which is $2.6 \%$ higher than the $\delta^{13} \mathrm{C}$ signatures of the studied beech leaf litter and close to the average $\delta^{13} \mathrm{C}$ signature of soil animals of the present study.

Higher similarity of stable isotope signatures of leaf litter and soil animals in coniferous as compared to beech forests suggests that soil animals in coniferous forests utilize more carbon and nitrogen from litter in the litter layer. Presumably, this is due to differences in microbial community structure. Decomposing coniferous needles typically are dominated by fungi whereas in beech litter bacteria contribute substantially to microbial biomass (Frostegard et al. 1993, Blagodatskaya and Anderson 1998, Chauvat et al. 2003) suggesting that detritivorous animals in coniferous forests more heavily feed on fungi thereby strengthening the fungal energy channel. Presumably, in coniferous forests a large fraction of litter resources are channeled via saprotrophic fungi into the soil animal food web whereas soil animals in beech forests more heavily rely on root derived resources with the bacterial energy channel being more pronounced (Pollierer et al. 2012, Cesarz et al. 2013).

Higher contribution of litter derived resources to soil animal nutrition in coniferous as compared to beech forests at first sight is counterintuitive as coniferous needles are rich in 
polyphenols and therefore of low quality for microbial and animal decomposers (Northup et al. 1998, Makkonen et al. 2012). However, taking into account that coniferous forests typically feature thicker litter layers than deciduous forests (Augusto et al. 2003), which was also true for the forests investigated $\left(0.79 \pm 0.37 \mathrm{~g} / \mathrm{cm}^{2}\right.$ and $0.50 \pm 0.25 \mathrm{~g} / \mathrm{cm}^{2}$ for coniferous and beech forests, respectively), the results point to a simple mechanism explaining variations in stable isotope signatures of consumers of forest ecosystems. $\Delta^{13} \mathrm{C}$ and $\Delta^{15} \mathrm{~N}$ values of soil animal species varied little (although significantly) with leaf litter C-to-N ratios and microbial biomass. In contrast, they varied markedly with the amount of litter in the litter layer. This suggests that the utilization of leaf litter resources by basal consumers of the soil animal food web mainly depends on the amount of litter resources available rather than on qualitative properties of the litter such as litter $\mathrm{C}$-to-N ratio or concentrations of litter microorganisms. Our results corroborate findings of Ott et al. (this issue) on biomass distributions of soil animals and of Ferlian and Scheu (this issue) on predator - prey interactions, underlining that habitat structure and access of litter resources is one of the main factors influencing the structure and functioning of soil animal food webs. Overall, the results suggest that physical factors such as the extension of the litter layer are of major importance for the structure of soil animal food webs by serving as habitat and resource but also by hampering access of detritivores to root derived resources.

\section{Conclusions}

Soil animal $\delta^{15} \mathrm{~N}$ and $\delta^{13} \mathrm{C}$ signatures vary with those of leaf litter, fine roots and soil, underlining that they need to be calibrated for allowing comparisons of species of different habitats and regions. Calibrated stable isotope signatures indicate that the general structure of soil animal food webs varies little with forest type and forest management. However, the results indicate that in coniferous forests litter as basal resource for the soil animal food web is more important than in beech forests. Presumably, thick litter layers in coniferous forests foster the fungal energy channel but hamper incorporation of root derived resources into the soil animal food web. Overall, the results suggest that structural habitat characteristics such as the thickness of organic layers outweigh litter quality as driving factor of soil animal food webs of temperate forest ecosystems.

\section{Acknowledgements}

We thank the managers of the three exploratories, Swen Renner, Sonja Gockel, Kerstin Wiesner, and Martin Gorke for their work in maintaining the plot and project infrastructure; 
Simone Pfeiffer and Christiane Fischer giving support through the central office, Michael Owonibi for managing the central data base, and Markus Fischer, Eduard Linsenmair, Dominik Hessenmöller, Jens Nieschulze, Daniel Prati, Ingo Schöning, François Buscot, Ernst-Detlef Schulze, Wolfgang W. Weisser and the late Elisabeth Kalko for their role in setting up the Biodiversity Exploratories project. Financial support by the German Research Foundation (DFG; Priority Program 1374 "Infrastructure-Biodiversity-Exploratories") is gratefully acknowledged. Field work permits were issued by the state environmental office of Baden-Württemberg, Thüringen, and Brandenburg (§ 72 BbgNatSchG).

\section{References}

Anderson, J. P. E. \& Domsch, K. H. (1980) Quantities of plant nutrients in the microbial biomass of selected soils. Soil Science, 130, 211-216.

Augusto, L., Dupouey, J. L. \& Ranger, J. (2003) Effects of tree species on understory vegetation and environmental conditions in temperate forests. Annals of Forest Science, 60, 823-831.

Bearhop, S., Adams, C. E., Waldron, S., Fuller, R. A. \& Macleod, H. (2004) Determining trophic niche width: a novel approach using stable isotope analysis. Journal of Animal Ecology, 73, 10071012.

Beck, T., Joergensen, R. G., Kandeler, E., Makeschin, F., Nuss, E., Oberholzer, H. R. \& Scheu, S. (1997) An inter-laboratory comparison of ten different ways of measuring soil microbial biomass C. Soil Biology \& Biochemistry, 29, 1023-1032.

Bengtsson, J., Nilsson, S. G., Franc, A. \& Menozzi, P. (2000) Biodiversity, disturbances, ecosystem function and management of European forests. Forest Ecology and Management, 132, 39-50.

Berg, M. P. \& Bengtsson, J. (2007) Temporal and spatial variability in soil food web structure. Oikos, $116,1789-1804$.

Blagodatskaya, E. V. \& Anderson, T. H. (1998) Interactive effects of $\mathrm{pH}$ and substrate quality on the fungal-to-bacterial ratio and $\mathrm{QCO}(2)$ of microbial communities in forest soils. Soil Biology \& Biochemistry, 30, 1269-1274.

Boeckx, P., Paulino, L., Oyarzun, C., van Cleemput, O. \& Godoy, R. (2005) Soil delta N-15 patterns in old-growth forests of southern Chile as integrator for $\mathrm{N}$-cycling. Isotopes in Environmental and Health Studies, 41, 249-259.

Cesarz, S., Fender, A.-C., Beyer, F., Valtanen, K., Pfeiffer, B., Gansert, D., Hertel, D., Polle, A., Daniel, R., Leuschner, C. \& Scheu, S. (2013) Roots from beech (Fagus sylvatica L.) and ash (Fraxinus excelsior L.) differentially affect soil microorganisms and carbon dynamics. Soil Biology \& Biochemistry, 61, 23-32.

Chauvat, M., Titsch, D., Zaytsev, A. S. \& Wolters, V. (2011) Changes in soil faunal assemblages during conversion from pure to mixed forest stands. Forest Ecology and Management, 262, 317-324. 
Chauvat, M., Zaitsev, A. S. \& Wolters, V. (2003) Successional changes of Collembola and soil microbiota during forest rotation. Oecologia, 137, 269-276.

Chevillat, V. S., Siegwolf, R. T. W., Pepin, S. \& Korner, C. (2005) Tissue-specific variation of delta C13 in mature canopy trees in a temperate forest in central Europe. Basic and Applied Ecology, 6, 519-534.

Cole, L., Bradford, M. A., Shaw, P. J. A. \& Bardgett, R. D. (2006) The abundance, richness and functional role of soil meso- and macrofauna in temperate grassland - A case study. Applied Soil Ecology, 33, 186-198.

Cragg, R. G. \& Bardgett, R. D. (2001) How changes in soil faunal diversity and composition within a trophic group influence decomposition processes. Soil Biology \& Biochemistry, 33, 2073-2081.

Crotty, F. V., Blackshaw, R. P. \& Murray, P. J. (2011) Tracking the flow of bacterially derived ${ }^{13} \mathrm{C}$ and ${ }^{15} \mathrm{~N}$ through soil faunal feeding channels. Rapid Communications in Mass Spectrometry, 25, 1503-1513.

DeNiro, M. J. \& Epstein, S. (1978) Influence of diet on distribution of carbon isotopes in animals. Geochimica et Cosmochimica Acta, 42, 495-506.

DeNiro, M. J. \& Epstein, S. (1981) Influence of diet on the distribution of nitrogen isotopes in animals. Geochimica et Cosmochimica Acta, 45, 341-351.

Digel, C., Riede, J. O., Curtsdotter, A. \& Brose, U. Unraveling the complex structure of forest soil food webs: High omnivory and more trophic levels. (this issue).

Eisenhauer, N., Straube, D. \& Scheu, S. (2008) Efficiency of two widespread non-destructive extraction methods under dry soil conditions for different ecological earthworm groups. European Journal of Soil Biology, 44, 141-145.

Eissfeller, V., Beyer, F., Valtanen, K., Hertel, D., Maraun, M., Polle, A. \& Scheu, S. (2013) Incorporation of plant carbon and microbial nitrogen into the rhizosphere food web of beech and ash. Soil Biology \& Biochemistry, 62, 76-81.

Ferlian, O. \& Scheu, S. Shifts in trophic interactions with forest type in soil generalist predators as indicated by complementary analyses of fatty acids and stable isotopes. (this issue).

Fischer, M., Bossdorf, O., Gockel, S., Hansel, F., Hemp, A., Hessenmoeller, D., Korte, G., Nieschulze, J., Pfeiffer, S., Prati, D., Renner, S., Schoening, I., Schumacher, U., Wells, K., Buscot, F., Kalko, E. K. V., Linsenmair, K. E., Schulze, E.-D. \& Weisser, W. W. (2010) Implementing large-scale and long-term functional biodiversity research: The Biodiversity Exploratories. Basic and Applied Ecology, 11, 473-485.

Frostegard, A., Baath, E. \& Tunlid, A. (1993) Shifts in the structure of soil microbial communities in limed forests as revealed by phospholipid fatty-acid analysis. Soil Biology \& Biochemistry, 25, 723-730.

Gessler, A., Rennenberg, H. \& Keitel, C. (2004) Stable isotope composition of organic compounds transported in the phloem of European beech - Evaluation of different methods of phloem sap collection and assessment of gradients in carbon isotope composition during leaf-to-stem transport. Plant Biology, 6, 721-729.

Hättenschwiler, S., Tiunov, A. V. \& Scheu, S. (2005) Biodiversity and litter decomposition in terrestrial ecosystems. Annual Review of Ecology Evolution and Systematics, 36, 191-218. 
Hedlund, K., Griffiths, B., Christensen, S., Scheu, S., Setala, H., Tscharntke, T. \& Verhoef, H. (2004) Trophic interactions in changing landscapes: responses of soil food webs. Basic and Applied Ecology, 5, 495-503.

Hynes, H. M. \& Germida, J. J. (2012) A chronsequential approach to investigating microbial community shifts following clearcutting in Boreal Plain forest soils. Canadian Journal of Forest Research-Revue Canadienne De Recherche Forestiere, 42, 2078-2089.

Joergensen, R. G. \& Scheu, S. (1999) Response of soil microorganisms to the addition of carbon, nitrogen and phosphorus in a forest Rendzina. Soil Biology \& Biochemistry, 31, 859-866.

Kempson, D., Lloyd, M. \& Ghelardi, R. (1963) A new extractor for woodland litter. Pedobiologia, 3, 121.

Kuptz, D., Matyssek, R. \& Grams, T. E. E. (2011) Seasonal dynamics in the stable carbon isotope composition (delta 13C) from non-leafy branch, trunk and coarse root $\mathrm{CO} 2$ efflux of adult deciduous (Fagus sylvatica) and evergreen (Picea abies) trees. Plant Cell and Environment, 34, 363-373.

Makkonen, M., Berg, M. P., Handa, I. T., Hattenschwiler, S., van Ruijven, J., van Bodegom, P. M. \& Aerts, R. (2012) Highly consistent effects of plant litter identity and functional traits on decomposition across a latitudinal gradient. Ecology Letters, 15, 1033-1041.

Maraun, M., Erdmann, G., Fischer, B. M., Pollierer, M. M., Norton, R. A., Schneider, K. \& Scheu, S. (2011) Stable isotopes revisited: their use and limits for oribatid mite trophic ecology. Soil Biology \& Biochemistry, 43, 877-882.

Martinez del Rio, C., Wolf, N., Carleton, S. A. \& Gannes, L. Z. (2009) Isotopic ecology ten years after a call for more laboratory experiments. Biological Reviews, 84, 91-111.

Moore-Kucera, J. \& Dick, R. P. (2008) PLFA profiling of microbial community structure and seasonal shifts in soils of a Douglas-fir chronosequence. Microbial Ecology, 55, 500-511.

Moore, J. C. \& DeRuiter, P. C. (1991) Temporal and spatial heterogeneity of trophic interactions within belowground food webs. Agriculture Ecosystems \& Environment, 34, 371-397.

Northup, R. R., Dahlgren, R. A. \& McColl, J. G. (1998) Polyphenols as regulators of plant-litter-soil interactions in northern California's pygmy forest: A positive feedback? Biogeochemistry, 42 , 189-220.

Norton, R. A. \& Behan-Pelletier, V. M. (1991) Calcium-carbonate and calcium-oxalate as cuticular hardening agents in oribatid mites (Acari, Oribatida). Canadian Journal of Zoology-Revue Canadienne De Zoologie, 69, 1504-1511.

Oelbermann, K. \& Scheu, S. (2010) Trophic guilds of generalist feeders in soil animal communities as indicated by stable isotope analysis $\left({ }^{15} \mathrm{~N} /{ }^{14} \mathrm{~N}\right)$. Bulletin of Entomological Research, 100, 511 520.

Ott, D., Digel, C., Seelig, C. \& Brose, U. Body masses and resource stoichiometry interactively constrain biomass distributions across forest soil food webs (this issue).

Paillet, Y., Berges, L., Hjalten, J., Odor, P., Avon, C., Bernhardt-Romermann, M., Bijlsma, R. J., De Bruyn, L., Fuhr, M., Grandin, U., Kanka, R., Lundin, L., Luque, S., Magura, T., Matesanz, S., Meszaros, I., Sebastia, M. T., Schmidt, W., Standovar, T., Tothmeresz, B., Uotila, A., Valladares, F., Vellak, K. \& Virtanen, R. (2010) Biodiversity Differences between Managed and 
Unmanaged Forests: Meta-Analysis of Species Richness in Europe. Conservation Biology, 24, 101-112.

Peterson, B. J. \& Fry, B. (1987) Stable isotopes in ecosystem studies. Annual Review of Ecology and Systematics, 18, 293-320.

Pollierer, M. M., Dyckmanns, J., Scheu, S. \& Haubert, D. (2012) Carbon flux through fungi and bacteria into the forest soil animal food as indicated by compound- specific ${ }^{13} \mathrm{C}$ fatty acid analysis. Functional Ecology, 26, 978-990.

Pollierer, M. M., Langel, R., Körner, C., Maraun, M. \& Scheu, S. (2007) The underestimated importance of belowground carbon input for forest soil animal food webs. Ecology Letters, 10, 729-736.

Pollierer, M. M., Langel, R., Scheu, S. \& Maraun, M. (2009) Compartmentalization of the soil animal food web as indicated by dual analysis of stable isotope ratios $\left({ }^{15} \mathrm{~N} /{ }^{14} \mathrm{~N}\right.$ and $\left.{ }^{13} \mathrm{C} /{ }^{12} \mathrm{C}\right)$. Soil Biology \& Biochemistry, 41, 1221-1226.

Ponsard, S. \& Arditi, R. (2000) What Can Stable Isotopes (Delta N-15 and Delta C-13) Tell About the Food Web of Soil Macro-Invertebrates? Ecology, 81, 852-864.

Post, D. M. (2002) Using stable isotopes to estimate trophic position: Models, methods, and assumptions. Ecology, 83, 703-718.

R Development Core Team (2008) R: A language and environment for statistical computing. R Foundation for Statistical Computing, Vienna, Austria.

Reineking, A., Langel, R. \& Schikowski, J. (1993) N-15,C-13-on-line measurement with an elemental analyzer (Carlo-Erba, NA-1500), a modified trapping box and a gas isotope massspectrometer (Finnigan, MAT-251) Isotopenpraxis, 29, 169-174.

Ruf, A., Kuzyakov, Y. \& Lopatovskaya, O. (2006) Carbon fluxes in soil food webs of increasing complexity revealed by C-14 labelling and C-13 natural abundance. Soil Biology \& Biochemistry, 38, 2390-2400.

Scheu, S. (1992) Automated measurement of the respiratory response of soil microcompartments active microbial biomass in eathworm faeces. Soil Biology \& Biochemistry, 24, 1113-1118.

Scheu, S. (2002) The soil food web: structure and perspectives. European Journal of Soil Biology, 38, $11-20$.

Scheu, S. \& Falca, M. (2000) The Soil Food Web of Two Beech Forests (Fagus Sylvatica) of Contrasting Humus Type: Stable Isotope Analysis of a Macro- and a Mesofauna-Dominated Community. Oecologia, 123, 285-296.

Schneider, K., Migge, S., Norton, R. A., Scheu, S., Langel, R., Reineking, A. \& Maraun, M. (2004) Trophic niche differentiation in soil microarthropods (Oribatida, Acari): evidence from stable isotope ratios (N-15/N-14). Soil Biology \& Biochemistry, 36, 1769-1774.

Siira-Pietikainen, A., Pietikainen, J., Fritze, H. \& Haimi, J. (2001) Short-term responses of soil decomposer communities to forest management: clear felling versus alternative forest harvesting methods. Canadian Journal of Forest Research-Revue Canadienne De Recherche Forestiere, 31, 88-99.

Tiunov, A. V. (2007) Stable isotopes of carbon and nitrogen in soil ecological studies. Biology Bulletin, 34, 395-407. 
Vanderklift, M. A. \& Ponsard, S. (2003) Sources of variation in consumer-diet delta N-15 enrichment: A meta-analysis. Oecologia, 136, 169-182.

Wang, N., Xu, S. S., Jia, X., Gao, J., Zhang, W. P., Qiu, Y. P. \& Wang, G. X. (2013) Variations in foliar stable carbon isotopes among functional groups and along environmental gradients in China a meta-analysis. Plant Biology, 15, 144-151.

Wardle, D. A. (2002) Communities and Ecosystems - Linking the Aboveground and Belowground Components. Princeton University Press, Princeton and Oxford. 


\section{Chapter 4}

Trophic diversity and niche partitioning in a species rich predator guild - natural variations in stable isotope ratios $\left({ }^{13} \mathrm{C} /{ }^{12} \mathrm{C},{ }^{15} \mathrm{~N} /{ }^{14} \mathrm{~N}\right.$ ) of mesostigmatid mites (Acari, Mesostigmata) from Central European beech forests

Bernhard Klarner, Mark Maraun and Stefan Scheu

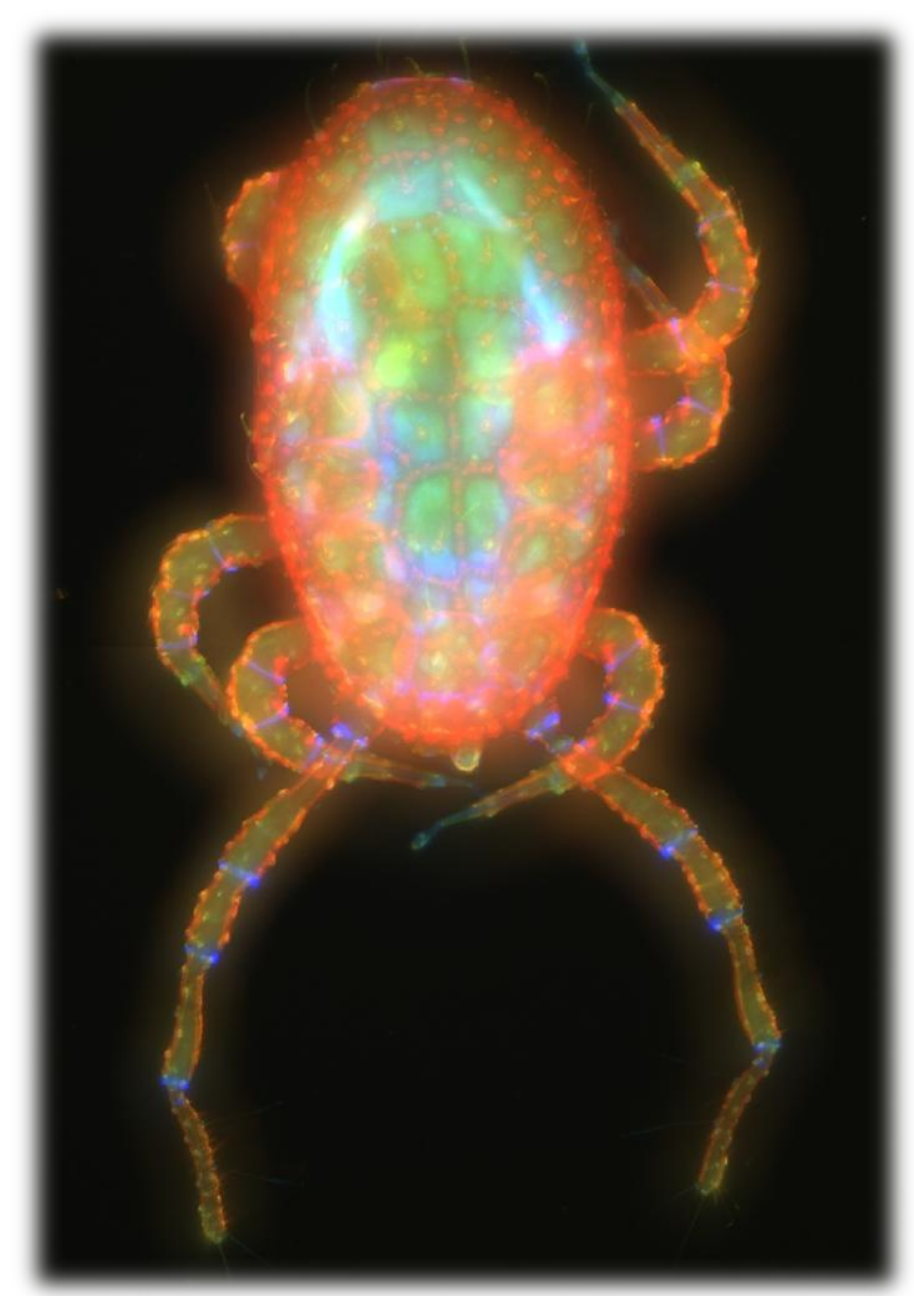

Published in:

Klarner, B., Maraun, M. \& Scheu, S. (2013) Trophic diversity and niche partitioning in a species rich predator guild - Natural variations in stable isotope ratios (C-13/C-12, N-15/N14) of mesostigmatid mites (Acari, Mesostigmata) from Central European beech forests. Soil Biology \& Biochemistry, 57, 327-333. 


\section{Abstract}

A large number of predatory mesostigmatid mite species populate forest soils in high densities. The present study investigates the trophic structure of the Mesostigmata community of old growth beech stands in Central Germany and identifies potential prey groups using natural variations in stable isotope ratios $\left({ }^{13} \mathrm{C} /{ }^{12} \mathrm{C}\right.$ and $\left.{ }^{15} \mathrm{~N} /{ }^{14} \mathrm{~N}\right)$. Data on relative abundances and body mass were included for each of the 40 species studied to analyze functional aspects in Mesostigmata feeding ecology. The results indicate that Mesostigmata predominantly feed on secondary decomposers, whereas primary decomposer and intraguild prey are of minor importance. Dominant species featured high $\delta^{13} \mathrm{C}$ signatures suggesting that they predominantly feed on species relying on root derived resources such as bacterial feeding nematodes. Less abundant species where characterized by lower $\delta^{13} \mathrm{C}$ values suggesting that they predominantly feed on prey relying on litter derived resources such as fungal feeding Collembola. Related taxa often had distinctively different isotope ratios suggesting that trophic niche partitioning facilitates coexistence of morphologically similar species. Unexpectedly, the trophic position of Mesostigmata species was not related to body size reflecting the varying trophic position of their main prey, nematodes and Collembola, suggesting that body size is a poor predictor of trophic position in soil food webs.

Key words: Mesostigmata, Uropodina, feeding ecology, stable isotopes, $\delta^{13} \mathrm{C}, \delta^{15} \mathrm{~N}$, body size, abundance, trophic niche 


\section{Introduction}

Mesostigmatid mites (Acari, Mesostigmata) are the main predators in mesofauna food webs of temperate forest and agricultural soils (Ruf and Beck 2005). In beech forests total biomass of Mesostigmata species, which typically are only few millimeters in length, is equivalent to that of predators such as centipedes (Chilopoda) and spiders (Araneida) with at least one magnitude larger body size (Schaefer 1990, Scheu et al. 2003). In numbers Mesostigmata surpass other arthropod predators by far, reaching typically 4,000 to 10,000 ind. $\mathrm{m}^{-2}$ (Schaefer 1990, Ruf and Beck 2005). Recent studies suggest that Mesostigmata are among the most effective predators in soil food webs; due to their high density they effectively control prey populations (Schneider et al. 2012).

Mesostigmata are diverse, about 1000 species are described for Central Europe (Karg 1993) and often more than 30 species co-occur on a single square meter of soil (Heldt 1995). Unfortunately, due to their small size Mesostigmata are rarely included in studies on trophic interactions in soil food webs. If included they usually are treated as a homogeneous functional group, ignoring species specific differences in prey spectra (Moore et al. 1988). Knowledge on the trophic ecology of Mesostigmata is primarily based on laboratory observations with only few species studied in detail. Feeding experiments indicate some specialization among Mesostigmata species, with preferences for prey with certain traits or taxonomic affiliation e.g., worm-like prey, microarthropods, Collembola or Nematoda (Karg 1983, 1986, 1989b, Walter 1988, Koehler 1999, Prischmann et al. 2011). These preferences can be linked to morphological features of the chelicerae, though the prey type could not be predicted reliably from cheliceral morphology (Buryn and Brandl 1992). Studies on feeding interactions of Mesostigmata in the field are missing entirely.

The analysis of stable isotope ratios of carbon $\left({ }^{13} \mathrm{C} /{ }^{12} \mathrm{C}\right)$ and nitrogen $\left({ }^{15} \mathrm{~N} /{ }^{14} \mathrm{~N}\right)$ is a well established tool for investigating the trophic structure of soil animal food webs (Scheu and Falca 2000, Tiunov 2007). The concentration of the heavy nitrogen isotope ${ }^{15} \mathrm{~N}$ increases from food sources to consumers and therefore isotope ratios of nitrogen can be used to ascribe species to trophic levels (DeNiro and Epstein 1981, Peterson and Fry 1987, Scheu 2002). The enrichment of ${ }^{15} \mathrm{~N}$ in consumers to some extent varies with diet, age, feeding type, excretion mode and taxonomic affiliation (Oelbermann and Scheu 2002, Vanderklift and Ponsard 2003, Haubert et al. 2005, Tiunov 2007), however, the average enrichment by $3.4 \%$ as proposed by Post (2002) has been found to be a reliable figure also applying to soil animals including predators (Schneider et al. 2004, Chahartaghi et al. 2005, Oelbermann and Scheu 2010). For detritivores the enrichment presumably is lower with an average of about 0.5\% (Vanderklift and Ponsard 2003, Oelbermann and Scheu 2010). In contrast to ${ }^{15} \mathrm{~N}$, concentrations of ${ }^{13} \mathrm{C}$ change little from diet to consumer thereby reflecting the signature of 
the basal food source (Deniro and Epstein 1978, Peterson and Fry 1987, Post 2002). Recent studies consider the variance of stable isotope signatures as a measure of the dietary niche width of consumers (Bearhop et al. 2004), a concept that has been expanded to the isotopic niche as a measure of niche dimensions of Hutchinson's (1957) n-dimensional hyper volume of an organisms ecological niche (Newsome et al. 2007).

A number of studies successfully used natural variations in stable isotope ratios to evaluate the trophic structure of soil animal communities (Ponsard and Arditi 2000, Scheu and Falca 2000, Halaj et al. 2005, Okuzaki et al. 2009, Pollierer et al. 2009), however, they either ignored Mesostigmata or included only few species. Using stable isotope methodology the present study for the first time investigates the trophic ecology of a wide range of Mesostigmata species. Forty species from 14 families of temperate deciduous forests were analyzed covering a wide spectrum of morphologies and behaviors of Mesostigmata. Assuming that the relative position in dual isotope space reflects the trophic niche of species we expected to be able to identify guilds with different prey spectra. By evaluating their trophic position under natural conditions in the field and by including basal resources of the soil animal food web the study aims at contributing to the understanding of this important predator group and their feeding interactions in soil food webs.

Furthermore, the study analyzes the relationship between body mass and trophic position in Mesostigmata. Body size is a major structuring factor of the architecture of food webs (Brose 2010), especially predator-prey interactions strongly depend on body mass ratios (Vucic-Pestic et al. 2010, Kalinkat et al. 2011) and trophic level has been shown to increase with body size (Woodward and Hildrew 2002, Riede et al. 2011). Therefore we expected that (1) large species occupy higher trophic levels than small species. Further, we hypothesized that (2) actively hunting Veigaiidae and Parasitidae occupy the highest trophic level due to intra-guild predation. In addition, we expected (3) nematode feeders, such as Uropodina and Zerconidae, to occupy low trophic levels by relying predominantly on decomposer prey species. Furthermore, we hypothesized that (4) isotope signatures of Mesostigmata change during ontogenesis, reflecting a change in prey spectrum with increase in body size.

\section{Materials and Methods}

\subsection{Sampling and extraction of soil animals}

Eight old growth beech stands were sampled in spring 2008. The study sites were located in the Hainich-Dün region, which is situated in a low mountain range in Central Germany and features large unfragmented forests composed primarily of beech (Fagus sylvatica). The 
Hainich-Dün is among the largest regions in Central Europe covered by beech forests spanning over about $1300 \mathrm{~km}^{2}$. The study sites form part of the "Biodiversity Exploratories", a large integrative biodiversity project (Fischer et al. 2010). Four of the selected sites have been left unmanaged since approximately 60 years, four sites were age class stands with a mean tree age of approximately 80 years; all sites were dominated by mature beech trees. The understory consisted of beech seedlings and spring geophytes, such as Allium ursinum, Anemone nemorosa and Galium odoratum. Parent material at the sites was loess over triassic limestone, soils were characterized as luvisols with mull or mull-like moder humus. Two small soil cores $(5 \mathrm{~cm} \varnothing)$ were taken at each site for an inventory of species of Mesostigmata. For stable isotope measurements larger soil cores $(20 \mathrm{~cm} \varnothing)$ were taken, two in age class stands and four in unmanaged stands. The litter layer and the upper $5 \mathrm{~cm}$ of each soil core were extracted separately using a modified heat extractor (Macfadyen 1961, Kempson et al. 1963).

\subsection{Identification of species and preparation of samples}

Mesostigmata species were identified using Karg (1989a, 1993). Animals were transferred into tin capsules and dried at $60^{\circ} \mathrm{C}$ for $24 \mathrm{~h}$ before measurement of stable isotopes. Three replicates per species from different sites were prepared if possible. For small and less common species individuals had to be pooled across sites; up to 70 individuals were pooled to gain the amount of material necessary for stable isotope analysis. For the species Dinychus perforatus, Trachytes aegrota, Trachytes pauperior, Uropoda cassidea and Uroseius cylindricus (for authorities see supplementary Table A1) three to four samples of adult females, deutonymphs and protonymphs ( $U$. cassidea and $U$. cylindricus only) were prepared to analyze variations in stable isotope signatures with life stage. For $D$. perforatus and $U$. cassidea samples of adult males were included to inspect potential differences between sexes. In total, 146 samples of 40 Mesostigmata species (see Table A1) were analyzed. Soil and litter material was dried, ground with a ball mill (Retsch Mixer Mill MM200, Haan, Germany) and transferred into tin capsules for measurement of stable isotopes. Additionally, stable isotope signatures of representative macrofauna predators (Chilopoda) and decomposers (Diplopoda) were measured and included for comparison (see supplementary Table A2). 


\subsection{Stable isotope analysis}

Stable isotope ratios were determined using a coupled system of an elemental analyzer (NA 1500, Carlo Erba, Milan, Italy) and a mass spectrometer (MAT 251, Finnigan, Bremen, Germany) (Reineking et al. 1993). Isotope signatures are expressed using the $\delta$ notation with $\delta X(\%)=\left(R_{\text {sample }}-R_{\text {standard }}\right) / R_{\text {standard }} X 1000$, where $X$ represents the target isotope and $R$ the ratio of heavy to light isotope $\left({ }^{13} \mathrm{C} /{ }^{12} \mathrm{C}\right.$ and ${ }^{15} \mathrm{~N} /{ }^{14} \mathrm{~N}$, respectively). Nitrogen in atmospheric air served as standard for $\delta^{15} \mathrm{~N}$ and Vienna PD Belemnite as standard for $\delta^{13} \mathrm{C}$ measurements. All animal stable isotope signatures were calibrated to the mean of the leaf litter signature of the respective sampling site to account for local variability in stable isotope signatures of basal resources.

\subsection{Data analysis}

Statistical analyses were performed using R 2.13.1 (R Development Core Team 2008) and the R Commander GUI (package "rcmdr"; Fox 2005). All data was tested for heteroscedasticity within grouping variables using Levene's test (function "leveneTest") and log transformed to improve homogeneity of variances if necessary. Single factor analysis of variance (function "aov") or a general linear model (function "Im") in case of unequal number of samples per group (ontogenetic stage or sex) was used to test for significant differences between $\delta^{13} \mathrm{C}$ and $\delta^{15} \mathrm{~N}$ signatures of different sexes and between juvenile stages and adults (of both sexes if possible) of the species studied.

Linear regression (function "Im") using the dry weights of adult individuals and their respective $\delta^{15} \mathrm{~N}$ signature was used to inspect if the trophic level of species increases with body mass. Linear regression using the relative abundances of species and their respective $\delta^{13} \mathrm{C}$ signatures was used to inspect if isotope signatures vary with the density of species. Linear regression using the relative abundance of species and their $\delta^{15} \mathrm{~N}$ signatures was used to inspect if the abundance of species is related to trophic level.

Convex hull envelopes were generated for the bivariate $\left(\delta^{13} \mathrm{C}\right.$ and $\left.\delta^{15} \mathrm{~N}\right)$ isotope signatures and total areas of the respective hulls determined using the function "laymanmetrics" of the package "SIAR" in R (Parnell A 2011). Threshold values for species with $5 \%, 2 \%$ and $1 \%$ relative abundance were used to compare the isotopic niche width of species differing in density. Additionally, convex hull envelopes were generated for species of genera with at least three samples of two or more species measured for a visual comparison of isotopic niches of related species. 


\section{Results}

\subsection{Basal resources}

Leaf litter stable isotope signatures differed little between the study sites, spanning $1.08 \delta$ units in ${ }^{13} \mathrm{C}\left(-29.43 \%\right.$ o to $-28.35 \%$ ) and $2.15 \delta$ units in ${ }^{15} \mathrm{~N}(-5.39 \%$ to $-3.24 \%$ o). Soil stable isotope signatures were more variable, spanning $4.17 \delta$ units in ${ }^{13} \mathrm{C}(-30.11 \%$ o to $-25.94 \%$ ) and $3.81 \delta$ units in ${ }^{15} \mathrm{~N}(-1.95 \%$ to $1.89 \%)$.

\subsection{Adult Mesostigmata}

Stable isotope signatures of adult Mesostigmata were enriched by at least $3.44 \%$ in ${ }^{13} \mathrm{C}$ and $1.01 \%$ in ${ }^{15} \mathrm{~N}$ relative to leaf litter and varied considerably between species. $\delta^{13} \mathrm{C}$ signatures of the species studied spanned $3.64 \delta$ units ranging from Rhodacarellus kreuzi with $-24.91 \%$ to $U$. cylindricus with $-21.27 \%$ (Fig. 1). Respective $\delta^{15} \mathrm{~N}$ signatures spanned $8.77 \delta$ units ranging from Leitneria granulata with $-2.23 \%$ to Zerconopsis remiger with $6.54 \%$ (Fig. 1). $\delta^{15} \mathrm{~N}$ signatures also varied within species e.g., in Pachylaelaps longisetus they spanned $4.08 \delta^{15} \mathrm{~N}$ units (Fig. 1). 


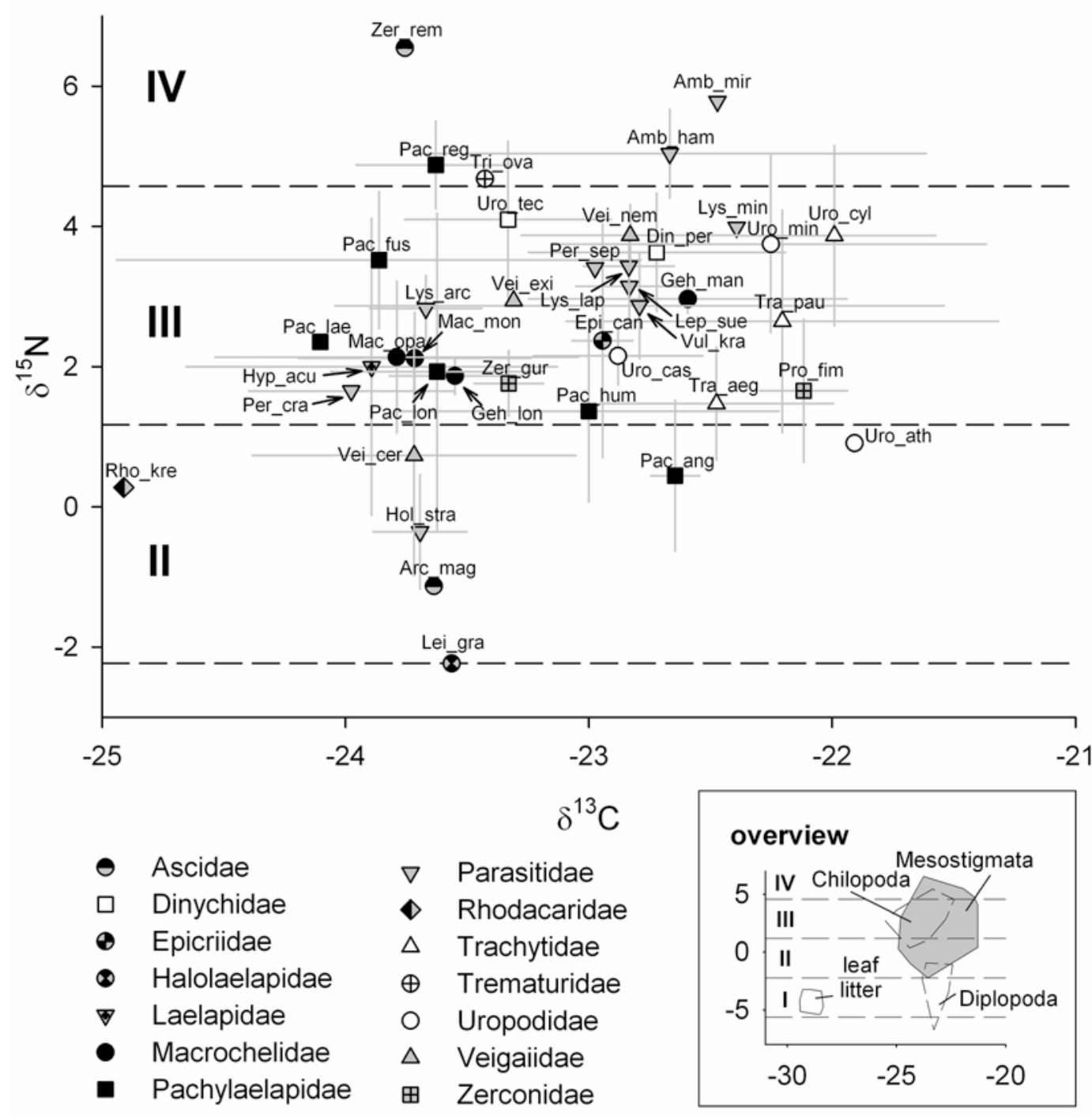

Fig. 1. Mean $( \pm S D)$ stable isotope signatures $\left(\delta^{13} \mathrm{C}\right.$ and $\left.\delta^{15} \mathrm{~N}\right)$ of Mesostigmata species in old-growth beech stands; polygons in the inlet represent convex hulls enveloping bivariate $\left(\delta^{13} \mathrm{C}\right.$ and $\left.\delta^{15} \mathrm{~N}\right)$ isotope signatures of Mesostigmata, Chilopoda, Diplopoda and leaf litter for comparison. Dashed horizontal lines represent estimated trophic level boundaries with each trophic level spanning $3.4 \%$, based on the mean $\delta^{15} \mathrm{~N}$ signature of leaf litter, a mean trophic level enrichment of $0.5 \%$ for primary decomposers (Vanderklift and Ponsard, 2003) and 3.4\%o for higher consumer levels (Minagawa and Wada, 1984; Post, 2002); I = primary decomposers, II = secondary decomposers and first order predators, III = second order predators, IV = third order predators; different symbols indicate different families of Mesostigmata; for full species names see supplementary Table A1.

\subsection{Variations with ontogenetic stage, sex and body size}

In U. cylindricus and $U$. cassidea $\delta^{13} \mathrm{C}$ and $\delta^{15} \mathrm{~N}$ signatures of protonymphs, deutonymphs and adults were measured. They did not differ significantly in $U$. cylindricus $\left(F_{2,6}=1.12, p=\right.$ 0.39 and $F_{1,4}=2.32, p=0.35$, respectively) but in $U$. cassidea this only applied to $\delta^{13} \mathrm{C}$ signatures $\left(F_{2,11}=0.05, p=0.96\right)$ whereas $\delta^{15} \mathrm{~N}$ signatures differed significantly between 
protonymphs and adults $\left(\mathrm{F}_{2,11}=6.74, \mathrm{p}=0.0123\right)$, decreasing from protonymphs $(2.66 \pm$ $0.40 \%$ ) to deutonymphs $(2.25 \pm 0.02 \%$ ) to adults $(2.03 \pm 0.24 \%$ ).

Neither $\delta^{13} \mathrm{C}$ nor $\delta^{15} \mathrm{~N}$ signatures differed significantly in any of the species in which we measured deutonymphs and adults $\left(F_{1,8}=0.01, p=0.92\right.$ and $F_{1,8}=1.40, p=0.26$ for $D$. perforatus, respectively; $F_{1,9}=2.03, p=0.19$ and $F_{1,9}=1.57, p=0.24$ for $T$. aegrota, respectively; $F_{1,4}=0.01, p=0.97$ and $F_{1,4}=0.06, p=0.81$ for $T$. pauperior, respectively).

Similarly, neither $\delta^{13} \mathrm{C}$ nor $\delta^{15} \mathrm{~N}$ signatures differed significantly between adult males and females in the two species analyzed $\left(F_{1,4}=0.68, p=0.46\right.$ and $F_{1,4}=0.13, p=0.74$ for $D$. perforatus, respectively; $F_{1,6}=0.31, p=0.60$ and $F_{1,6}=0.11, p=0.75$ for $U$. cassidea, respectively).

Linear regression indicated that $\delta^{15} \mathrm{~N}$ signatures neither significantly increased with body mass in the dataset of all adults $\left(r^{2}=0.01, p=0.35\right.$, Fig. 2$)$, nor in subsets of data including only Parasitidae and Veigaiidae $\left(r^{2}=0.03, p=0.35\right)$, or Uropodina and Zerconidae $\left(r^{2}=0.04\right.$, $\mathrm{p}=0.18)$.

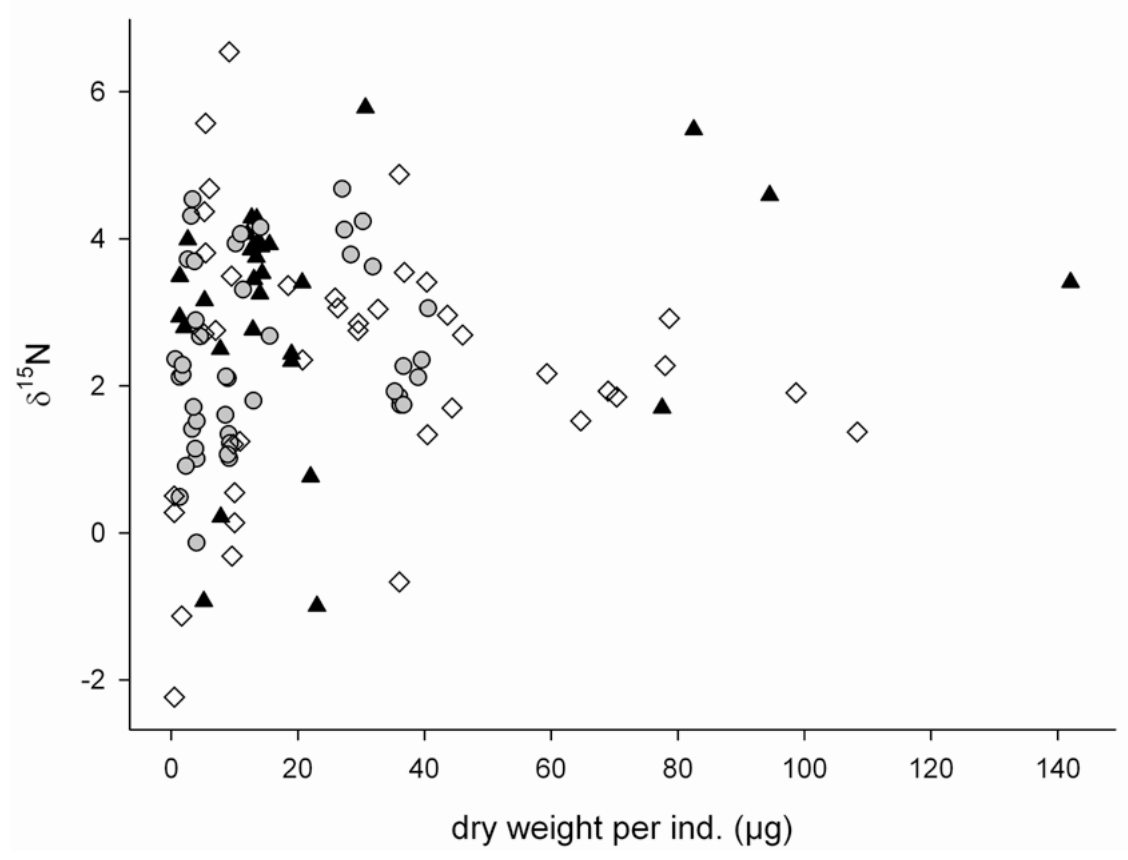

Fig. 2. Relationship between body size and trophic level as indicated by $\delta^{15} \mathrm{~N}$ signatures of adult Mesostigmata; none of the regression calculated for all species, arthropod hunting Parasitidae and Veigaiidae (black triangles), and nematode feeding Uropodina and Zerconidae (open diamonds) were significant $(p>0.05)$. 


\subsection{Variations in isotopic niches}

The area covered by the bivariate isotope signatures (total area) of Mesostigmata increased gradually when including less common species (Fig. 3a). Total area increased from 9.74 for the threshold of $5 \%$ relative abundance of the species included, to 14.02 for the $2 \%, 21.77$ for the $1 \%$ threshold and 22.99 for all species studied. Linear regression indicated increasing $\delta^{13} \mathrm{C}$ signatures with increasing relative abundance of species $\left(r^{2}=0.13, p=\right.$ 0.0001 ; Fig. 3b), but no such increase in $\delta^{15} \mathrm{~N}$ signatures $\left(r^{2}=0.01, p=0.92\right)$.
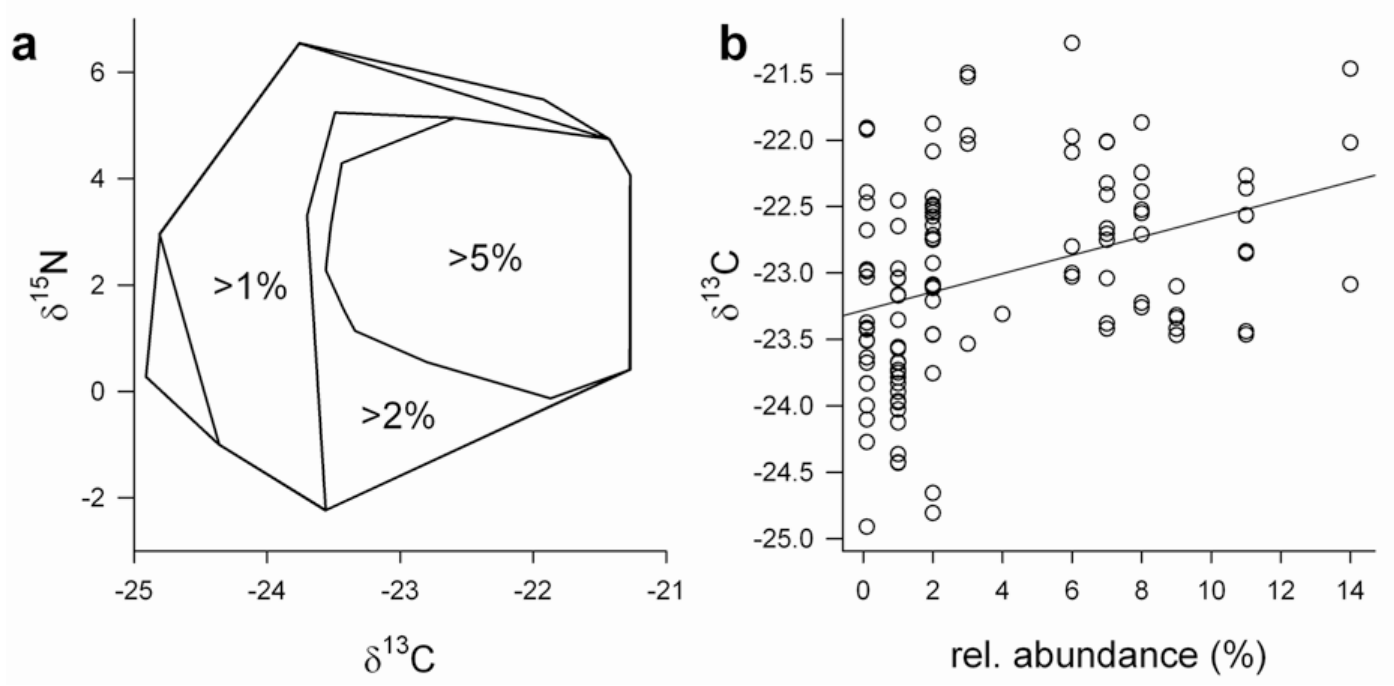

Fig. 3. (a) Total area occupied by Mesostigmata in dual $\left(\delta^{13} \mathrm{C}\right.$ and $\left.\delta^{15} \mathrm{~N}\right)$ isotopic space as related to the relative abundance of species; the outermost line represents the convex hull envelope of all species analyzed, successively smaller areas represent convex hulls for thresholds of relative abundances equal to $1 \%, 2 \%$ and $5 \%$; (b) relationship between relative abundance and $\delta^{13} \mathrm{C}$ signatures in Mesostigmata (linear regression, $r^{2}=0.13, p<0.001$ ).

While signatures of species of different families frequently overlapped (Fig. 1), signatures of closely related species (i.e., species of the same genus) often formed distinctly separated planes in dual isotopic space. In the genera Uropoda (Fig. 4a), Pachylaelaps (Fig. 4b) and Geholaspis (Fig. 4d) the hull areas of the species studied were fully separated. In the genus Veigaia hull areas of $V$. cerva and $V$. nemorensis were also distinct, but the dot of the singular measurement of $V$. exigua was located at the border of the hull area of $V$. nemorensis (Fig. 4c). The hull area of $T$. aegrota in part overlapped with that of $T$. pauperior (Fig. 4e), due to very variable $\delta^{15} \mathrm{~N}$ signatures in $T$. pauperior, which spanned $4.13 \delta$ units. The genus Macrocheles was exceptional with similar $\delta^{13} \mathrm{C}$ and $\delta^{15} \mathrm{~N}$ signatures of $M$. montanus and M. opacus aciculatus (Fig. 4f). 

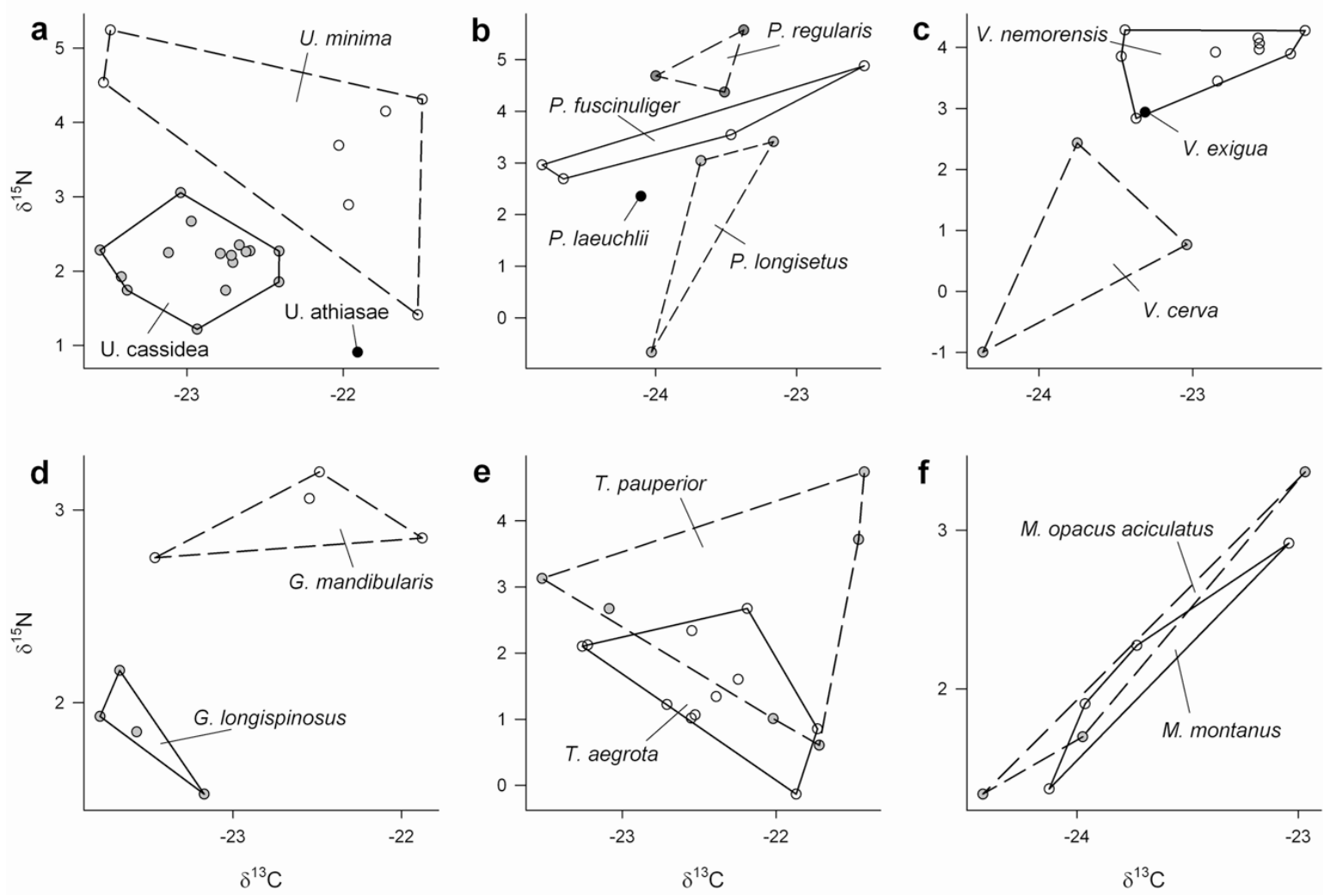

Fig. 4. Isotopic niches of species of the same genus co-occurring in old-growth beech stands; polygons represent convex hulls enveloping the bivariate $\left(\delta^{13} \mathrm{C}\right.$ and $\left.\delta^{15} \mathrm{~N}\right)$ isotope signatures of each species; filled circles represent single measurements; for full species names see supplementary Table A1.

\section{Discussion}

All 40 analyzed Mesostigmata species were strongly enriched in $\delta^{15} \mathrm{~N}$ relative to leaf litter with signatures similar to those of large arthropod predators, such as spiders, staphylinids and centipedes (Scheu and Falca 2000, Pollierer et al. 2009). This indicates that irrespective of their small body size, Mesostigmata occupy high trophic positions in the soil food web. The broad range of $\delta^{13} \mathrm{C}$ and $\delta^{15} \mathrm{~N}$ signatures supports the view that Mesostigmata species feed on a variety of prey from different trophic levels and feeding types. Prey taxa, such as Collembola, Nematoda and other Acari (Karg 1989a, 1993, Koehler 1999, Heidemann et al. 2011), comprise primary and secondary decomposers as well as predators (Schneider et al. 2004, Chahartaghi et al. 2005, Maraun et al. 2011). Assuming a ${ }^{15} \mathrm{~N}$ enrichment of $3-4 \%$ per trophic level (DeNiro and Epstein 1981, Minagawa and Wada 1984, Post 2002) the span of $\delta^{15} \mathrm{~N}$ of $8.4 \%$ o suggests that Mesostigmata utilize prey from all three trophic levels.

All Mesostigmata species studied were also enriched in ${ }^{13} \mathrm{C}$ compared to leaf litter, indicating that their prey relies on carbon sources with a more enriched $\delta^{13} \mathrm{C}$ signature than bulk leaf litter material. A similar enrichment was found throughout studies on natural isotope 
ratios of carbon in forest soil animals (Ponsard and Arditi 2000, Okuzaki et al. 2009, Pollierer et al. 2009, Semenyuk and Tiunov 2011). This increase in $\delta^{13} \mathrm{C}$ values suggests that soil animal food webs rely in large on plant components less depleted in ${ }^{13} \mathrm{C}$ than bulk plant litter (Pollierer et al. 2009). As suggested previously, the use of root-derived resources may significantly contribute to the shift in $\delta^{13} \mathrm{C}$ values between plant tissue and soil animal species (Pollierer et al. 2007) as phloem sap $\delta^{13} \mathrm{C}$ signatures of beech (forming the basis of root exudates) are high (Gessler et al. 2004). High $\delta^{13} \mathrm{C}$ signatures of basal species are passed on to predators which rely almost exclusively on prey from the decomposer subsystem (Scheu 2001, 2002, Miyashita et al. 2003, Oelbermann et al. 2008).

Compared to the large range of isotopic signatures of all Mesostigmata species studied, the dominant species occupied a relatively narrow range of $\delta^{13} \mathrm{C}$ and $\delta^{15} \mathrm{~N}$ signatures, indicating that most of their prey species occupy similar and rather narrow niches. $\delta^{15} \mathrm{~N}$ signatures of the dominant Mesostigmata species were in the range of second order predators suggesting that secondary decomposers (and potentially also first order predators) form the dominant prey of Mesostigmata, whereas primary decomposers are of minor importance. It is increasingly recognized that primary decomposers form only a small fraction of soil animal species among e.g., Diplopoda (Pollierer et al. 2009, Semenyuk and Tiunov 2011), Lumbricidae (Schmidt et al. 2004, Pollierer et al. 2009), Collembola (Chahartaghi et al. 2005) and Oribatida (Schneider et al. 2004, Maraun et al. 2011). Typically, these groups are well protected against predation due to large body size, strong sclerotization and/or chemical defense and therefore contribute little to predator nutrition (Scheu 2002).

$\delta^{13} \mathrm{C}$ signatures of most of the dominant Mesostigmata species were high. This may be due to high contribution of prey from deeper soil strata, since $\delta^{13} \mathrm{C}$ signatures increase with soil depth (Bostrom et al. 2007) and soil dwelling species therefore are more enriched in ${ }^{13} \mathrm{C}$ (Tiunov 2007). However, species included in this study predominantly colonize the litter and uppermost soil layer; prey species therefore likely also originated predominantly from these layers and not from deeper soil layers. Most of the species of the hull area of dominant species are slow moving and possess small pincer-like chelicerae (e.g., Uropodina and Zerconidae). Commonly, this is considered to indicate nematode feeding (Buryn and Brandl 1992, Koehler 1999). However, the hull area also comprised species with larger chelicerae and a more active foraging behavior such as Pergamasus septentrionalis and $V$. nemorensis. $P$. septentrionalis recently has been shown to also feed on nematodes in the field using molecular gut content analysis (Peschel et al. 2006, Heidemann et al. 2011) and $V$. nemorensis readily consumes nematodes in the laboratory (B. Klarner, pers. observation). This suggests that the diet of dominant Mesostigmata species consists in large of nematode prey; unfortunately, due to the small body size, stable isotope data of nematodes of 
temperate forests are not available. Nematodes at our study sites comprise mainly bacterial feeders $(\sim 50 \%)$, plant (root) feeders $(\sim 35 \%)$, fungal feeders $(<5 \%)$ and predators $(<5 \%$; L. Ruess, pers. comm.). This suggests that among nematodes of old growth beech forests bacterial and root feeding species form the main prey of Mesostigmata. This supports the view that bacteria form an important component of the diet of higher order consumers and bacterial carbon is channeled to top level predators of soil food webs (Crotty et al. 2011, Pollierer et al. 2012).

Low $\delta^{13} \mathrm{C}$ signatures, i.e., signatures closer to those of plant litter, mainly occurred in Collembola hunting specialists such as Pergamasus crassipes and $V$. cerva, in generalists such as Hypoaspis aculeifer, but also in Macrochelidae and Pachylaelapidae, which are assumed to mainly feed on - compared to nematodes - large "worm like" prey such as Diptera larvae and Enchytraeidae (Koehler 1999). These Mesostigmata species likely occupy trophic niches similar to those of macrofauna predators such as Chilopoda. Their $\delta^{15} \mathrm{~N}$ signatures also indicate feeding on secondary decomposers. Overall, stable isotope signatures and literature data suggest that their prey predominantly comprises fungal feeding Collembola rather than Nematoda. This is consistent with the low $\delta^{13} \mathrm{C}$ signatures of these Mesostigmata species resembling signatures of saprotrophic litter decaying fungi (Bostrom et al. 2008). Low relative abundances in this group further support the view that complex litter compounds are utilized predominantly by microbial decomposers with little of this carbon passed on to higher consumer levels (Pollierer et al. 2007).

Some species, such as Z. remiger, Pachylaelaps regularis and both Amblygamasus species, had exceptionally high $\delta^{15} \mathrm{~N}$ signatures pointing to intra-guild predation (Ponsard and Arditi 2000, Halaj et al. 2005). A. hamatus and A. mirabilis are comparatively large and therefore may feed on other Mesostigmata; $Z$. remiger and $P$. regularis are rather small and therefore likely feed on predatory Nematoda and/or small predatory/scavenging Collembola.

Body size also varied considerably in species of the lower and medium range of $\delta^{15} \mathrm{~N}$ signatures. Predator size typically increases with trophic level (Riede et al. 2011), but this appears not to be the case in Mesostigmata as their $\delta^{15} \mathrm{~N}$ signatures were not related to body mass. Body size of species of nematode feeders, such as Uropodina and Zerconidae, and active arthropod hunters, such as Parasitidae and Veigaiidae, also spanned over a wide range suggesting that prey of both of these predator guilds originates from a broad range of trophic levels and size classes.

Generally, stable isotope signatures varied little with developmental stage and sex suggesting that the prey spectrum of the studied species is rather constant irrespective of body size and sex. However, the slightly decreasing $\delta^{15} \mathrm{~N}$ signatures with successive 
developmental stage in $U$. cassidea indicate that in this species the prey spectrum changes during ontogeny, but the changes are moderate. In some species (e.g., P. longisetus) stable isotope signatures of adults varied markedly suggesting generalistic feeding on locally abundant prey.

Signatures of species of different taxonomic affiliation (different family) overlapped widely. In part this is due to the fact that signatures of species of certain families e.g., Parasitidae, spread across large ranges in bivariate isotopic space. Therefore, characters used to define higher taxonomic units such as families are not related to the feeding mode or food spectrum. On the contrary, trophic niches of closely related Mesostigmata species i.e., species from the same genus, such as $P$. regularis, $P$. fuscinuliger, $P$. laeuchlii and $P$. longisetus, often were separated markedly in at least one of the two isotopic niche dimensions. This indicates that trophic niche partitioning contributes to the coexistence of morphologically similar species and may have contributed to diversification of Mesostigmata species. However, in some cases related species apparently occupy similar niches e.g., isotope signatures of $M$. montanus and M. opacus aciculatus were similar. Species of this genus are assumed to feed on Diptera larvae and Nematoda developing in temporarily available resources such as decaying plant remains or dung (Koehler 1999). Predators in food webs of such resource patches with a single basal resource are likely to have similar stable isotope signatures, and communities in such habitats are unlikely to be structured by competition for resources thereby allowing coexistence of trophically similar species.

The amount of material needed for stable isotope analysis currently necessitates to pool samples of small animals for measurement. This limits the analysis of variations in the isotope signatures of small soil animal species. Lowering detection thresholds for ${ }^{13} \mathrm{C}$ and ${ }^{15} \mathrm{~N}$ in mass spectrometry is needed to allow deeper insight into the role of niche partitioning in meso- and microfauna soil food webs. More individual based data of soil animals will allow evaluating community wide isotopic niche width metrics, an approach that has been successfully used in aquatic food webs (Layman et al. 2007, Jackson et al. 2011).

\section{Conclusions}

Overall, stable isotope signatures reflect that the prey of mesostigmatid mites is diverse with individual species occupying distinct niches which vary little with ontogenetic stage and sex. Notably, related species usually have well separated trophic niches. $\delta^{15} \mathrm{~N}$ signatures suggest that most of the prey of Mesostigmata comprises secondary decomposers with primary decomposers and intraguild prey being less important. Presumably, due to the varying body size of their prey the trophic position of Mesostigmata does not increase with 
body size. Dominant species likely feed to a large extent on nematodes with their prey relying strongly on root derived carbon. Less abundant species presumably rely more on fungal feeding species such as Collembola obtaining their carbon from saprotrophic fungi i.e., from the plant litter energy channel. More detailed studies employing fatty acid and molecular gut content analysis are needed to fully appreciate the complex feeding relationships in soil food webs and the role of Mesostigmata therein.

\section{Acknowledgements}

We thank the managers of the three exploratories, Swen Renner, Sonja Gockel, Andreas Hemp and Martin Gorke and Simone Pfeiffer for their work in maintaining the plot and project infrastructure and Markus Fischer, the late Elisabeth Kalko, Eduard Linsenmair, Dominik Hessenmöller, Jens Nieschulze, Daniel Prati, Ingo Schöning, François Buscot, Ernst-Detlef Schulze and Wolfgang W. Weisser for their role in setting up the Biodiversity Exploratories project. We are grateful for help and comments by Georgia Erdmann, Melanie Maraun, Roswitha Ehnes and Bernhard Eitzinger. Financial support by the German Research Foundation (DFG; Priority Program 1374 "Infrastructure-Biodiversity-Exploratories") is gratefully acknowledged. Field work permits were issued by the state environmental office of Thüringen (§ 72 BbgNatSchG).

\section{References}

Bearhop, S., Adams, C.E., Waldron, S., Fuller, R.A., Macleod, H., 2004. Determining trophic niche width: A novel approach using stable isotope analysis. Journal of Animal Ecology 73, 10071012.

Bostrom, B., Comstedt, D., Ekblad, A., 2007. Isotope fractionation and C-13 enrichment in soil profiles during the decomposition of soil organic matter. Oecologia 153, 89-98.

Bostrom, B., Comstedt, D., Ekblad, A., 2008. Can isotopic fractionation during respiration explain the C-13-enriched sporocarps of ectomycorrhizal and saprotrophic fungi? New Phytologist 177, 1012-1019.

Brose, U., 2010. Body-mass constraints on foraging behaviour determine population and food-web dynamics. Functional Ecology 24, 28-34.

Buryn, R., Brandl, R., 1992. Are the morphometrics of chelicerae correlated with diet in mesostigmatid mites (Acari). Experimental and Applied Acarology 14, 67-82.

Chahartaghi, M., Langel, R., Scheu, S., Ruess, L., 2005. Feeding guilds in Collembola based on nitrogen stable isotope ratios. Soil Biology \& Biochemistry 37, 1718-1725. 
Crotty, F.V., Blackshaw, R.P., Murray, P.J., 2011. Tracking the flow of bacterially derived 13C and $15 \mathrm{~N}$ through soil faunal feeding channels. Rapid Communications in Mass Spectrometry 25, 1503-1513.

Deniro, M.J., Epstein, S., 1978. Influence of diet on distribution of carbon isotopes in animals. Geochimica et Cosmochimica Acta 42, 495-506.

DeNiro, M.J., Epstein, S., 1981. Influence of diet on the distribution of nitrogen isotopes in animals. Geochimica et Cosmochimica Acta 45, 341-351.

Fischer, M., Bossdorf, O., Gockel, S., Hansel, F., Hemp, A., Hessenmoeller, D., Korte, G., Nieschulze, J., Pfeiffer, S., Prati, D., Renner, S., Schoening, I., Schumacher, U., Wells, K., Buscot, F., Kalko, E.K.V., Linsenmair, K.E., Schulze, E.-D., Weisser, W.W., 2010 Implementing largescale and long-term functional biodiversity research: The biodiversity exploratories. Basic and Applied Ecology 11, 473-485.

Fox, J., 2005. The R Commander: A basic-statistics graphical user interface to R. Journal of Statistical Software 14.

Gessler, A., Rennenberg, H., Keitel, C., 2004. Stable isotope composition of organic compounds transported in the phloem of european beech - evaluation of different methods of phloem sap collection and assessment of gradients in carbon isotope composition during leaf-to-stem transport. Plant Biology 6, 721-729.

Halaj, J., Peck, R.W., Niwa, C.G., 2005. Trophic structure of a macroarthropod litter food web in managed coniferous forest stands: A stable isotope analysis with delta $\mathrm{N}-15$ and delta $\mathrm{C}-13$. Pedobiologia 49, 109-118.

Haubert, D., Langel, R., Scheu, S., Ruess, L., 2005. Effects of food quality, starvation and life stage on stable isotope fractionation in Collembola. Pedobiologia 49, 229-237.

Heidemann, K., Scheu, S., Ruess, L., Maraun, M., 2011. Molecular detection of nematode predation and scavenging in oribatid mites: Laboratory and field experiments. Soil Biology \& Biochemistry 43, 2229-2236.

Heldt, S., 1995. Zur Kenntnis der Raubmilbenfauna (Acari: Gamasina) Bremens 1. Gegenüberstellung zweier Bestandsaufnahmen von 1906 und 1993, 2. Die Besiedlung ausgewählter Grünland- u. Waldstandorte im Bürgerpark. Abhandlungen des Naturwissenschaftlichen Vereins Bremen 43, 91-115.

Hutchinson, G.E., 1957. Population studies - animal ecology and demography - concluding remarks. Cold Spring Harbor Symposia on Quantitative Biology 22, 415-427.

Jackson, A.L., Inger, R., Parnell, A.C., Bearhop, S., 2011. Comparing isotopic niche widths among and within communities: Siber - stable isotope bayesian ellipses in R. Journal of Animal Ecology 80, 595-602.

Kalinkat, G., Rall, B.C., Vucic-Pestic, O., Brose, U., 2011. The allometry of prey preferences. PLoS One 6.

Karg, W., 1983. Distribution and importance of predatory mites of the cohort Gamasina in relation to their effects on nematodes. Pedobiologia 25, 419-432.

Karg, W., 1986. Habitats and nutrition of the cohors Uropodina (Acari) (turtle-mites) and their usefulness as indicators in agroecosystems. Pedobiologia 29, 285-295. 
Karg, W., 1989a. Acari (Acarina), Milben. Parasitiformes (Anactinochaeta). Uropodina Kramer, Schildkrötenmilben, In: Dahl, F. (Ed.), Die Tierwelt Deutschlands. Gustav Fischer, Jena.

Karg, W., 1989b. The importance of the prey-relations and host-relations of parasitiform mites for soilbiological analyses of defined areas. Pedobiologia 33, 1-15.

Karg, W., 1993. Acari (Acarina), Milben. Parasitiformes (Anactinochaeta). Cohors Gamasina Leach. Raubmilben, In: Dahl, F. (ed.), Die Tierwelt Deutschlands, 2nd ed. Gustav Fischer, Jena.

Kempson, D., Lloyd, M., Ghelardi, R., 1963. A new extractor for woodland litter. Pedobiologia 3, 1-21. Koehler, H.H., 1999. Predatory mites (Gamasina, Mesostigmata). Agriculture Ecosystems and Environment 74, 395-410.

Layman, C.A., Arrington, D.A., Montana, C.G., Post, D.M., 2007. Can stable isotope ratios provide for community-wide measures of trophic structure? Ecology 88, $42-48$.

Macfadyen, A., 1961. Improved funnel-type extractors for soil arthropods. Journal of Animal Ecology 30, 171-184.

Maraun, M., Erdmann, G., Fischer, B.M., Pollierer, M.M., Norton, R.A., Schneider, K., Scheu, S., 2011. Stable isotopes revisited: Their use and limits for oribatid mite trophic ecology. Soil Biology \& Biochemistry 43, 877-882.

Minagawa, M., Wada, E., 1984. Stepwise enrichment of N-15 along food-chains - further evidence and the relation between delta- $\mathrm{N}-15$ and animal age. Geochimica et Cosmochimica Acta 48, 11351140.

Miyashita, T., Takada, M., Shimazaki, A., 2003. Experimental evidence that aboveground predators are sustained by underground detritivores. Oikos 103, 31-36.

Moore, J.C., Walter, D.E., Hunt, H.W., 1988. Arthropod regulation of microbiota and mesobiota in belowground detrital food webs. Annual Review of Entomology 33, 419-439.

Newsome, S.D., del Rio, C.M., Bearhop, S., Phillips, D.L., 2007. A niche for isotopic ecology. Frontiers in Ecology and the Environment 5, 429-436.

Oelbermann, K., Langel, R., Scheu, S., 2008. Utilization of prey from the decomposer system by generalist predators of grassland. Oecologia 155, 605-617.

Oelbermann, K., Scheu, S., 2002. Effects of prey type and mixed diets on survival, growth and development of a generalist predator, Pardosa lugubris (Araneae : Lycosidae). Basic and Applied Ecology 3, 285-291.

Oelbermann, K., Scheu, S., 2010. Trophic guilds of generalist feeders in soil animal communities as indicated by stable isotope analysis (15N/14N). Bulletin of Entomological Research 100, 511 520.

Okuzaki, Y., Tayasu, I., Okuda, N., Sota, T., 2009. Vertical heterogeneity of a forest floor invertebrate food web as indicated by stable-isotope analysis. Ecological Research 24, 1351-1359.

Parnell A, I.R., Bearhop S, Jackson AL, 2011. Siar: Stable isotope analysis in R.

Peschel, K., Norton, R.A., Scheu, S., Maraun, M., 2006. Do oribatid mites live in enemy-free space? Evidence from feeding experiments with the predatory mite Pergamasus septentrionalis. Soil Biology \& Biochemistry 38, 2985-2989.

Peterson, B.J., Fry, B., 1987. Stable isotopes in ecosystem studies. Annual Review of Ecology and Systematics 18, 293-320. 
Pollierer, M.M., Dyckmanns, J., Scheu, S., Haubert, D., 2012. Carbon flux through fungi and bacteria into the forest soil animal food web investigated with component specific fatty acid analysis. Functional Ecology, in press.

Pollierer, M.M., Langel, R., Korner, C., Maraun, M., Scheu, S., 2007. The underestimated importance of belowground carbon input for forest soil animal food webs. Ecology Letters 10, 729-736.

Pollierer, M.M., Langel, R., Scheu, S., Maraun, M., 2009. Compartmentalization of the soil animal food web as indicated by dual analysis of stable isotope ratios (15N/14N and $13 \mathrm{C} / 12 \mathrm{C})$. Soil Biology \& Biochemistry 41, 1221-1226.

Ponsard, S., Arditi, R., 2000. What can stable isotopes (delta N-15 and delta C-13) tell about the food web of soil macro-invertebrates? Ecology 81, 852-864.

Post, D.M., 2002. Using stable isotopes to estimate trophic position: Models, methods, and assumptions. Ecology 83, 703-718.

Prischmann, D.A., Knutson, E.M., Dashiell, K.E., Lundgren, J.G., 2011. Generalist-feeding subterranean mites as potential biological control agents of immature corn rootworms. Experimental and Applied Acarology 55, 233-248.

R Development Core Team, 2008. R: A language and environment for statistical computing. $R$ Foundation for Statistical Computing, Vienna, Austria.

Reineking, A., Langel, R., Schikowski, J., 1993. N-15,C-13-on-line measurements with an elemental analyzer (Carlo-Erba, Na-1500), a modified trapping box and a gas isotope massspectrometer (Finnigan, MAT-251). Isotopenpraxis 29, 169-174.

Riede, J.O., Brose, U., Ebenman, B., Jacob, U., Thompson, R., Townsend, C.R., Jonsson, T., 2011. Stepping in Elton's footprints: A general scaling model for body masses and trophic levels across ecosystems. Ecology Letters 14, 169-178.

Ruf, A., Beck, L., 2005. The use of predatory soil mites in ecological soil classification and assessment concepts, with perspectives for oribatid mites. Ecotoxicology and Environmental Safety 62, 290-299.

Schaefer, M., 1990. The soil fauna of a beech forest on limestone - trophic structure and energy budget. Oecologia 82, 128-136.

Scheu, S., 2001. Plants and generalist predators as links between the below-ground and aboveground system. Basic and Applied Ecology 2, 3-13.

Scheu, S., 2002. The soil food web: Structure and perspectives. European Journal of Soil Biology 38, 11-20.

Scheu, S., Albers, D., Alphei, J., Buryn, R., Klages, U., Migge, S., Platner, C., Salamon, J.A., 2003. The soil fauna community in pure and mixed stands of beech and spruce of different age: Trophic structure and structuring forces. Oikos 101, 225-238.

Scheu, S., Falca, M., 2000. The soil food web of two beech forests (Fagus sylvatica) of contrasting humus type: Stable isotope analysis of a macro- and a mesofauna-dominated community. Oecologia 123, 285-296.

Schmidt, O., Curry, J.P., Dyckmans, J., Rota, E., Scrimgeour, C.M., 2004. Dual stable isotope analysis (delta C-13 and delta N-15) of soil invertebrates and their food sources. Pedobiologia 48, 171 180. 
Schneider, F.D., Scheu, S., Brose, U., 2012. Body mass constraints on feeding rates determine the consequences of predator loss. Ecology Letters 15, 436-443.

Schneider, K., Migge, S., Norton, R.A., Scheu, S., Langel, R., Reineking, A., Maraun, M., 2004. Trophic niche differentiation in soil microarthropods (Oribatida, Acari): Evidence from stable isotope ratios (N-15/N-14). Soil Biology \& Biochemistry 36, 1769-1774.

Semenyuk, I.I., Tiunov, A.V., 2011. Isotopic signature (15N/14N and 13C/12C) confirms similarity of trophic niches of millipedes (Myriapoda, Diplopoda) in a temperate deciduous forest. Biology Bulletin 38, 283-291.

Tiunov, A.V., 2007. Stable isotopes of carbon and nitrogen in soil ecological studies. Biology Bulletin 34, 395-407.

Vanderklift, M.A., Ponsard, S., 2003. Sources of variation in consumer-diet delta N-15 enrichment: A meta-analysis. Oecologia 136, 169-182.

Vucic-Pestic, O., Rall, B.C., Kalinkat, G., Brose, U., 2010. Allometric functional response model: Body masses constrain interaction strengths. Journal of Animal Ecology 79, 249-256.

Walter, D.E., Hunt, H.W. and Elliott, E.T., 1988. Guilds or functional groups? An analysis of predatory arthopods from a shortgras steppe soil. Pedobiologia 31, 247 - 260.

Woodward, G., Hildrew, A.G., 2002. Body-size determinants of niche overlap and intraguild predation within a complex food web. Journal of Animal Ecology 71, 1063-1074. 


\section{Chapter 5}

\section{General Discussion}

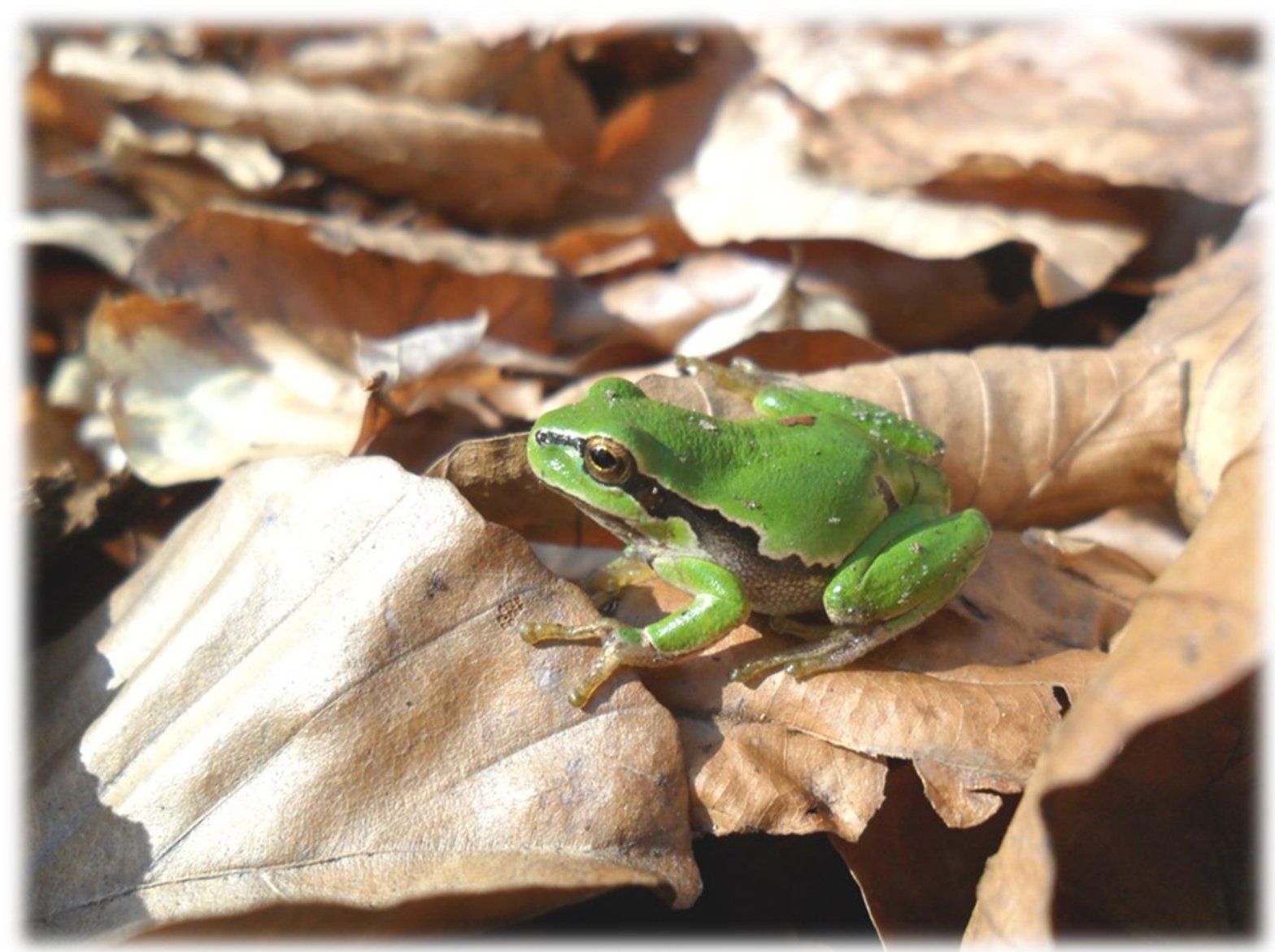




\section{General discussion}

The results of this thesis represent major advances in understanding the structure of soil food webs and the factors controlling it. By compiling and evaluating a comprehensive dataset on animal communities and habitat characteristics of forest soils in a large scale field study, we investigated the structuring forces of belowground communities in unprecedented detail. By employing stable isotope analysis as an indirect approach to investigate trophic interactions in soil, we achieved novel insight into the resource use of belowground communities and the trophic ecology of predatory microarthropods.

The results of the first study (Chapter 2) showed that regional variations of environmental factors, especially of soil $\mathrm{pH}$, strongly impact species composition and structure of soil animal communities; the data support previous findings that soil $\mathrm{pH}$ shapes decomposer communities of forests, which change from macrofauna dominated in base-rich soils to mesofauna dominated in acidic soils (Schaefer and Schauermann 1990). Taking benefit of a replicated research design covering three different geographic regions we accounted for regional variation, and distinguished and characterized additional effects of forest type and management on the soil food web.

The analysis of habitat conditions indicated increasing disturbance of the microbial decomposer community and decreasing rates of litter decomposition with forest management intensity. Within regions species composition of soil animal communities changed concomitantly with forest type and management, with highest differences between coniferous forests and unmanaged beech forests.

Abundance and biomass of mesofauna decomposers were highest in coniferous forests, presumably due to thick litter layers providing ample resources and habitat structure. The data support the hypothesis that the thickness of leaf litter layers functions as major driving factor for variations in soil animal abundance and biomass (Berg and Bengtsson 2007, Erdmann et al. 2012).

Overall, the functional structure and diversity of soil animal communities was little affected by forest type, indicating that soil animal food webs are buffered against changes in forest land use. This is likely facilitated by the opportunistic nature of feeding interactions in soil; generalism and omnivory are common strategies among soil animals (Gunn and Cherrett 1993, Eggers and Jones 2000, Ponsard and Arditi 2000, Scheu 2002) and it is assumed that many soil animal species are functionally redundant (Hättenschwiler et al. 2005, Wardle 2006). 
To investigate changes in the diet of individual species and in the trophic structure of soil food webs with forest type in detail, we measured variations of natural stable isotope ratios $\left({ }^{13} \mathrm{C} /{ }^{12} \mathrm{C}\right.$ and $\left.{ }^{15} \mathrm{~N} /{ }^{14} \mathrm{~N}\right)$ of a broad selection of soil animal species sampled from research sites of the previous study. The results of this second study (Chapter 3 ) indicate that the trophic structure and resource use of soil animals in general is little affected by management of beech forests, supporting the view that the overall architecture of soil food webs is buffered against anthropogenic disturbances. However, the results suggest that soil animals utilize more leaf litter derived resources in coniferous as compared to beech forests. As coniferous needles are rich in polyphenols and of low quality for microbial and animal decomposers (Northup et al. 1998, Makkonen et al. 2012), the shift towards this unfavorable resource appears counterintuitive. Notably, however, the trophic shift was persistent across different species and consumer levels suggesting major changes in resource use by basal species with the signal propagating to higher consumer levels.

Based on these findings we inspected how the utilization of litter derived resources by soil animals is affected by the amount of leaf litter in the litter layer, $\mathrm{C}$-to-N ratios of leaf litter and concentration of microorganisms in leaf litter. The results suggest that the thickness of organic layers outweighs litter quality as driving factor of soil animal food webs. This adds a new perspective to research on linkages between soil biota and organic matter decomposition, which to date mostly focused on the role of litter quality, diversity and climate (Wardle et al. 1997, Hättenschwiler and Vitousek 2000, Gonzalez and Seastedt 2001, Wardle et al. 2006).

Overall, the results suggest that the trophic shift of soil animals towards litter derived resources in coniferous forests is related to structural habitat changes, presumably due to the formation of thick litter layers formed by recalcitrant coniferous needle litter. It is increasingly recognized that, in addition to leaf litter, root exudates contribute substantially to the nutrition of soil food webs, especially in beech forests (Pollierer et al. 2007, Pollierer et al. 2012, Cesarz et al. 2013). Presumably, in coniferous forests thick leaf litter layers hamper the access of soil animals to root derived resources and thereby fostering the utilization of leaf litter resources. The role of structural habitat characteristics as driving factor for resource - consumer relationships in soil food webs is a fruitful area for future research.

The third study (Chapter 4) focused on the trophic ecology of mesostigmatid mites (Mesostigmata), a main group of predators in temperate forest and agricultural soils (Schaefer 1990, Scheu et al. 2003, Ruf and Beck 2005). Due to high densities Mesostigmata presumably effectively control prey populations (Schneider et al. 2012); however, due to their small size they are little investigated and knowledge on their prey spectrum to date primarily is based on laboratory observations with only few species studied in detail (Karg 1989, 
Walter and Ikonen 1989, Karg 1993, Koehler 1999, Heidemann et al. 2011, Prischmann et al. 2011). We investigated variations in stable isotope signatures of 40 common species of mesostigmatid mites in old growth beech stands; the results represent the first comprehensive study on the trophic structure of this important predator group based on field data.

Stable isotope signatures indicate that the prey of Mesostigmata comprises mostly secondary decomposers with primary decomposers and intra-guild prey being less important. Including data on community structure suggests that the prey of dominant species consists to a large extent of bacterial and root feeding nematodes. Thereby, Mesostigmata occupy a central trophic niche in the soil food web and exploit prey that is inaccessible for large sized predators.

The trophic position of Mesostigmata species did not increase with body size, presumably due to the varying body size of their prey. This contrasts the general pattern that body size increases with trophic level (Cohen et al. 1993, Woodward and Hildrew 2002, Brose 2010, Riede et al. 2011) and has major implications for theoretical considerations on the trophic structure of soil food webs.

Stable isotope signatures further indicate distinct prey spectra of species suggesting that trophic niche differentiation facilitates the diversity of soil predators similar to species rich groups of detritivores such as oribatid mites and collembolans (Schneider et al. 2004, Chahartaghi et al. 2005, Erdmann et al. 2007, Maraun et al. 2011).

Overall, the patterns described in this thesis show that trophic niches of soil animal species are distinct and likely based on mixtures of dietary resources or prey species. This conclusion is consistent with the view that dietary flexibility and generalism represent important strategies in soil animal species, resulting in soil food webs being resistant against anthropogenic disturbances and environmental changes.

More research is needed to more comprehensively resolve the role of omnivory and appreciate the complexity of trophic interactions in soil animal communities. Novel techniques provide complementary information on the diet of Mesostigmata and soil animals in general, and resolve major questions which puzzled soil ecologists for long. For example, the analysis of the composition of fatty acid of soil animal species allows investigating the contribution of fungal- and bacterial-based energy channels to the nutrition of soil animals (Pollierer et al. 2012). Further, molecular gut content analyses provide detailed insight into feeding links at various levels of taxonomic resolution (Symondson 2002, Eitzinger et al. 2013). Finally, isotopic labeling experiments allow tracking the pathway of carbon and 
nitrogen from plants to the rhizosphere to soil animal consumers (Ruf et al. 2006, Eissfeller et al. 2013).

Being time and cost efficient, the analysis of natural variations of stable isotope ratios remains the tool of choice for large scale studies on the trophic structure of soil animal communities. Advances in mass spectrometry, such as lowering the detection level for stable isotopes, provide the opportunity to investigate the trophic structure of soil microfauna such as nematodes. Results of the present study and recent publications (Read et al. 2006, Heidemann et al. 2011) suggest that nematodes form the major link between microorganisms as most important primary decomposers in soil and in the rhizosphere to meso- and macrofauna predators, thereby channeling basal resources to higher consumer levels (Bais et al. 2006, Eissfeller et al. 2013). Investigating these links is of central importance to more comprehensively understand the structure and functioning of soil food webs.

\section{References}

Bais, H. P., Weir, T. L., Perry, L. G., Gilroy, S. \& Vivanco, J. M. (2006) The role of root exudates in rhizosphere interations with plants and other organisms. Annual Review of Plant Biologypp. 233-266. Annual Reviews, Palo Alto.

Berg, M. P. \& Bengtsson, J. (2007) Temporal and spatial variability in soil food web structure. Oikos, 116, $1789-1804$

Brose, U. (2010) Body-mass constraints on foraging behaviour determine population and food-web dynamics. Functional Ecology, 24, 28-34.

Cesarz, S., Fender, A.-C., Beyer, F., Valtanen, K., Pfeiffer, B., Gansert, D., Hertel, D., Polle, A., Daniel, R., Leuschner, C. \& Scheu, S. (2013) Roots from beech (Fagus sylvatica L.) and ash (Fraxinus excelsior L.) differentially affect soil microorganisms and carbon dynamics. Soil Biology \& Biochemistry, 61, 23-32.

Chahartaghi, M., Langel, R., Scheu, S. \& Ruess, L. (2005) Feeding guilds in collembola based on nitrogen stable isotope ratios. Soil Biology \& Biochemistry, 37, 1718-1725.

Cohen, J. E., Pimm, S. L., Yodzis, P. \& Saldana, J. (1993) Body size of animal predators and animal prey in food webs. Journal of Animal Ecology, 62, 67-78.

Eggers, T. \& Jones, T. H. (2000) You are what you eat ... or are you? Trends in Ecology \& Evolution, 15, 265-266.

Eissfeller, V., Beyer, F., Valtanen, K., Hertel, D., Maraun, M., Polle, A. \& Scheu, S. (2013) Incorporation of plant carbon and microbial nitrogen into the rhizosphere food web of beech and ash. Soil Biology \& Biochemistry, 62, 76-81. 
Eitzinger, B., Micic, A., Körner, M., Traugott, M. \& Scheu, S. (2013) Unveiling soil food web links: New PCR assays for detection of prey DNA in the gut of soil arthropod predators. Soil Biology \& Biochemistry, 57, 943-945.

Erdmann, G., Otte, V., Langel, R., Scheu, S. \& Maraun, M. (2007) The trophic structure of bark-living oribatid mite communities analysed with stable isotopes (N-15, C-13) indicates strong niche differentiation. Experimental and Applied Acarology, 41, 1-10.

Erdmann, G., Scheu, S. \& Maraun, M. (2012) Regional factors rather than forest type drive the community structure of soil living oribatid mites (Acari, Oribatida). Experimental and Applied Acarology, 57, 157-169.

Gonzalez, G. \& Seastedt, T. R. (2001) Soil fauna and plant litter decomposition in tropical and subalpine forests. Ecology (Washington D C), 82, 955-964.

Gunn, A. \& Cherrett, J. M. (1993) The exploitation of food resources by soil meso-invertebrates and macro-invertebrates. Pedobiologia, 37, 303-320.

Hättenschwiler, S., Tiunov, A. V. \& Scheu, S. (2005) Biodiversity and litter decomposition in terrestrial ecosystems. Annual Review of Ecology Evolution and Systematics, 36, 191-218.

Hättenschwiler, S. \& Vitousek, P. M. (2000) The role of polyphenols in terrestrial ecosystem nutrient cycling. Trends in Ecology and Evolution, 15, 238-243.

Heidemann, K., Scheu, S., Ruess, L. \& Maraun, M. (2011) Molecular detection of nematode predation and scavenging in oribatid mites: Laboratory and field experiments. Soil Biology \& Biochemistry, 43, 2229-2236.

Karg, W. (1989) Acari (Acarina), Milben. Parasitiformes (Anactinochaeta). Uropodina Kramer, Schildkrötenmilben. Gustav Fischer, Jena.

Karg, W. (1993) Acari (Acarina), Milben. Parasitiformes (Anactinochaeta). Cohors Gamasina Leach. Raubmilben. Gustav Fischer, Jena.

Koehler, H. H. (1999) Predatory Mites (Gamasina, Mesostigmata). Agriculture Ecosystems and Environment, 74, 395-410.

Makkonen, M., Berg, M. P., Handa, I. T., Hattenschwiler, S., van Ruijven, J., van Bodegom, P. M. \& Aerts, R. (2012) Highly consistent effects of plant litter identity and functional traits on decomposition across a latitudinal gradient. Ecology Letters, 15, 1033-1041.

Maraun, M., Erdmann, G., Fischer, B. M., Pollierer, M. M., Norton, R. A., Schneider, K. \& Scheu, S. (2011) Stable isotopes revisited: Their use and limits for oribatid mite trophic ecology. Soil Biology \& Biochemistry, 43, 877-882.

Northup, R. R., Dahlgren, R. A. \& McColl, J. G. (1998) Polyphenols as regulators of plant-litter-soil interactions in northern California's pygmy forest: A positive feedback? Biogeochemistry, 42 , 189-220.

Pollierer, M. M., Dyckmanns, J., Scheu, S. \& Haubert, D. (2012) Carbon flux through fungi and bacteria into the forest soil animal food as indicated by compound- specific $13 \mathrm{C}$ fatty acid analysis. Functional Ecology, 26, 978-990.

Pollierer, M. M., Langel, R., Körner, C., Maraun, M. \& Scheu, S. (2007) The underestimated importance of belowground carbon input for forest soil animal food webs. Ecology Letters, 10, 729-736. 
Ponsard, S. \& Arditi, R. (2000) What can stable isotopes (delta N-15 and delta C-13) tell about the food web of soil macro-invertebrates? Ecology, 81, 852-864.

Prischmann, D. A., Knutson, E. M., Dashiell, K. E. \& Lundgren, J. G. (2011) Generalist-feeding subterranean mites as potential biological control agents of immature corn rootworms. Experimental and Applied Acarology, 55, 233-48.

Read, D. S., Sheppard, S. K., Bruford, M. W., Glen, D. M. \& Symondson, W. O. C. (2006) Molecular detection of predation by soil micro-arthropods on nematodes. Molecular Ecology, 15, 19631972.

Riede, J. O., Brose, U., Ebenman, B., Jacob, U., Thompson, R., Townsend, C. R. \& Jonsson, T. (2011) Stepping in Elton's footprints: a general scaling model for body masses and trophic levels across ecosystems. Ecology Letters, 14, 169-178.

Ruf, A. \& Beck, L. (2005) The use of predatory soil mites in ecological soil classification and assessment concepts, with perspectives for oribatid mites. Ecotoxicology and Environmental Safety, 62, 290-299.

Ruf, A., Kuzyakov, Y. \& Lopatovskaya, O. (2006) Carbon fluxes in soil food webs of increasing complexity revealed by C-14 labelling and C-13 natural abundance. Soil Biology \& Biochemistry, 38, 2390-2400.

Schaefer, M. (1990) The soil fauna of beech forest on limestone - trophic structure and energy budget. Oecologia, 82, 128-136.

Schaefer, M. \& Schauermann, J. (1990) The soil fauna of beech forests - comparison between a mull and moder soil. Pedobiologia, 34, 299-314.

Scheu, S. (2002) The soil food web: Structure and perspectives. European Journal of Soil Biology, 38, 11-20.

Scheu, S., Albers, D., Alphei, J., Buryn, R., Klages, U., Migge, S., Platner, C. \& Salamon, J. A. (2003) The soil fauna community in pure and mixed stands of beech and spruce of different age: trophic structure and structuring forces. Oikos, 101, 225-238.

Schneider, F. D., Scheu, S. \& Brose, U. (2012) Body mass constraints on feeding rates determine the consequences of predator loss. Ecology Letters, 15, 436-443.

Schneider, K., Migge, S., Norton, R. A., Scheu, S., Langel, R., Reineking, A. \& Maraun, M. (2004) Trophic niche differentiation in soil microarthropods (Oribatida, Acari): evidence from stable isotope ratios (N-15/N-14). Soil Biology \& Biochemistry, 36, 1769-1774.

Symondson, W. O. C. (2002) Molecular identification of prey in predator diets. Molecular Ecology, 11, 627-641.

Walter, D. E. \& Ikonen, E. K. (1989) Species, guilds, and functional-groups - taxonomy and behaviour in nematophageous arthropods. Journal of Nematology, 21, 315-327.

Wardle, D. A. (2006) The influence of biotic interactions on soil biodiversity. Ecology Letters, 9, 870886.

Wardle, D. A., Bonner, K. I. \& Nicholson, K. S. (1997) Biodiversity and plant litter: Experimental evidence which does not support the view that enhanced species richness improves ecosystem function. Oikos, 79, 247-258. 
Wardle, D. A., Yeates, G. W., Barker, G. M. \& Bonner, K. I. (2006) The influence of plant litter diversity on decomposer abundance and diversity. Soil Biology \& Biochemistry, 38, 1052-1062.

Woodward, G. \& Hildrew, A. G. (2002) Body-size determinants of niche overlap and intraguild predation within a complex food web. Journal of Animal Ecology, 71, 1063-1074. 


\section{Acknowledgements}

Mein besonderer Dank gilt:

Stefan, für die Möglichkeit als Teil Deiner Arbeitsgruppe viel zu erleben, zu lernen und an meinen Aufgaben zu wachsen.

Mark, dafür dass Deine Tür immer offen stand wenn ich Fragen hatte oder einfach ein paar Worte quatschen mochte.

Melanie, Georgia, Bernhard, Olga, Christian, Garvin, Rosi, Uli, Liliane, Gregor, Christoph; unsere gemeinsame Feldarbeit in den Exploratorien und alles drumherum habe ich immer sehr genossen.

Christel, Susanne, Ingrid, Andrea, Guido und Dieter für Eure tatkräftige Unterstützung in allen technischen und organisatorischen Dingen.

Simone, Olaf und Marcel; ein dickes Danke fürs Mitbewohnen, es hat sich in der Böttingerstraße nie wie in einer Zweck WG angefühlt.

Patrick, Kerstin, Martin, Garvin, David, Jens, Doro, Nils, Franca, Nicole und Diana für die unterhaltsamen Spieleabende.

Allen aktuellen und ehemaligen Mitgliedern der Arbeitsgruppe für die gemeinsame Zeit.

Julia, Jonas, Pascal, Alex, Eike, Hannes; Danke für Euren Support von Zuhause.

Meine Eltern und meine Familie; Ihr habt mir immer gezeigt dass Ihr Stolz auf mich seid.

Anna Lena, Dir danke ich besonders; Du hast die letzte anstrengende Phase meiner Doktorarbeit mit mir ausgehalten und so viel angenehmer gemacht.

Allen die ich vergessen habe. 


\section{List of publications}

\section{Published in peer-reviewed journals:}

Birkhofer, K., Schöning, I., Alt, F., Herold, N., Klarner, B., Maraun, M., Marhan, S., Oelmann, Y., Wubet, T., Yurkov, A., Begerow, D., Berner, D., Buscot, F., Daniel, R., Diekötter, T., Ehnes, R. B., Erdmann, G., Fischer, C., Foesel, B., Groh, J., Gutknecht, J., Kandeler, E., Lang, C., Lohaus, G., Meyer, A., Nacke, H., Nather, A., Overmann, J., Polle, A., Pollierer, M. M., Scheu, S., Schloter, M., Schulze, E. D., Schulze, W., Weinert, J., Weisser, W. W., Wolters, V. \& Schrumpf, M. (2012) General Relationships between Abiotic Soil Properties and Soil Biota across Spatial Scales and Different Land-Use Types. Plos One, 7, 8.

Eisenhauer, N., Milcu, A., Sabais, A. C. W., Bessler, H., Brenner, J., Engels, C., Klarner, B., Maraun, M., Partsch, S., Roscher, C., Schonert, F., Temperton, V. M., Thomisch, K., Weigelt, A., Weisser, W. W. \& Scheu, S. (2010) Plant diversity surpasses plant functional groups and plant productivity as driver of soil biota in the long term. PLoS One, $6,11$.

Klarner, B., Maraun, M. \& Scheu, S. (2013) Trophic diversity and niche partitioning in a species rich predator guild - Natural variations in stable isotope ratios (C-13/C-12, N-15/N-14) of mesostigmatid mites (Acari, Mesostigmata) from Central European beech forests. Soil Biology \& Biochemistry, 57, 327-333.

\section{Submitted:}

Digel, C., Riede, J. O., Curtsdotter, A., Klarner, B. \& Brose, U. (submitted) Unraveling the complex structure of forest soil food webs: High omnivory and more trophic levels.

Ehnes, R. B., Pollierer, M. M., Erdmann, G., Klarner, B., Eitzinger, B., Digel, C., Ott, D., Maraun, M., Scheu, S. \& Brose, U. (accepted) Lack of energetic equivalence in forest soil invertebrates.

Klarner, B., Ehnes, R. B., Erdmann, G., Eitzinger, B., Pollierer, M. M., Maraun, M. \& Scheu, S. (submitted) Trophic shift of soil animal species with forest type as indicated by stable isotope analysis. 


\section{Thesis declarations}

Declaration of the author's own contribution to manuscripts with multiple authors

Chapters 2 is based on a dataset that was compiled by or under supervision of Georgia Erdmann, Melanie M. Pollierer, Bernhard Eitzinger, Roswitha B. Ehnes, David Ott, Christoph Digel and me.

Chapter 3 comprises a manuscript that is currently submitted to a peer reviewed journal; Melanie Pollierer, Roswitha B. Ehnes, Georgia Erdmann and Bernhard Eitzinger helped with the identification of species and provided data on microbial concentrations in soil and litter, I have collected all stable isotope data of soil animals and resources and C-to- $\mathrm{N}$ ratios of resources.

Chapter 4 has been published as manuscript in a peer-reviewed journal. I have collected all data.

I am the first author of all manuscripts; I have analyzed the data, written the manuscripts, developed the main ideas, created tables, figures and appendices and contributed significantly to the study design.

The study design of each study was developed in the framework of project "LitterLinks" as part of the "Biodiversity Exploratories".

All persons contributing to the manuscripts have been named so. All co-authors contributed to finalising the manuscripts.

\section{Plagiarism declaration}

I declare that I have written this doctoral thesis independently. All persons contributing to the manuscripts have been named so. All sentences or passages quoted from other people's work have been specifically acknowledged by clear cross-referencing. I have not submitted this thesis in any form for another degree at any university or institution.

Bernhard Klarner

Göttingen, September 2013 


\section{Supplementary material}

\section{Chapter 2}

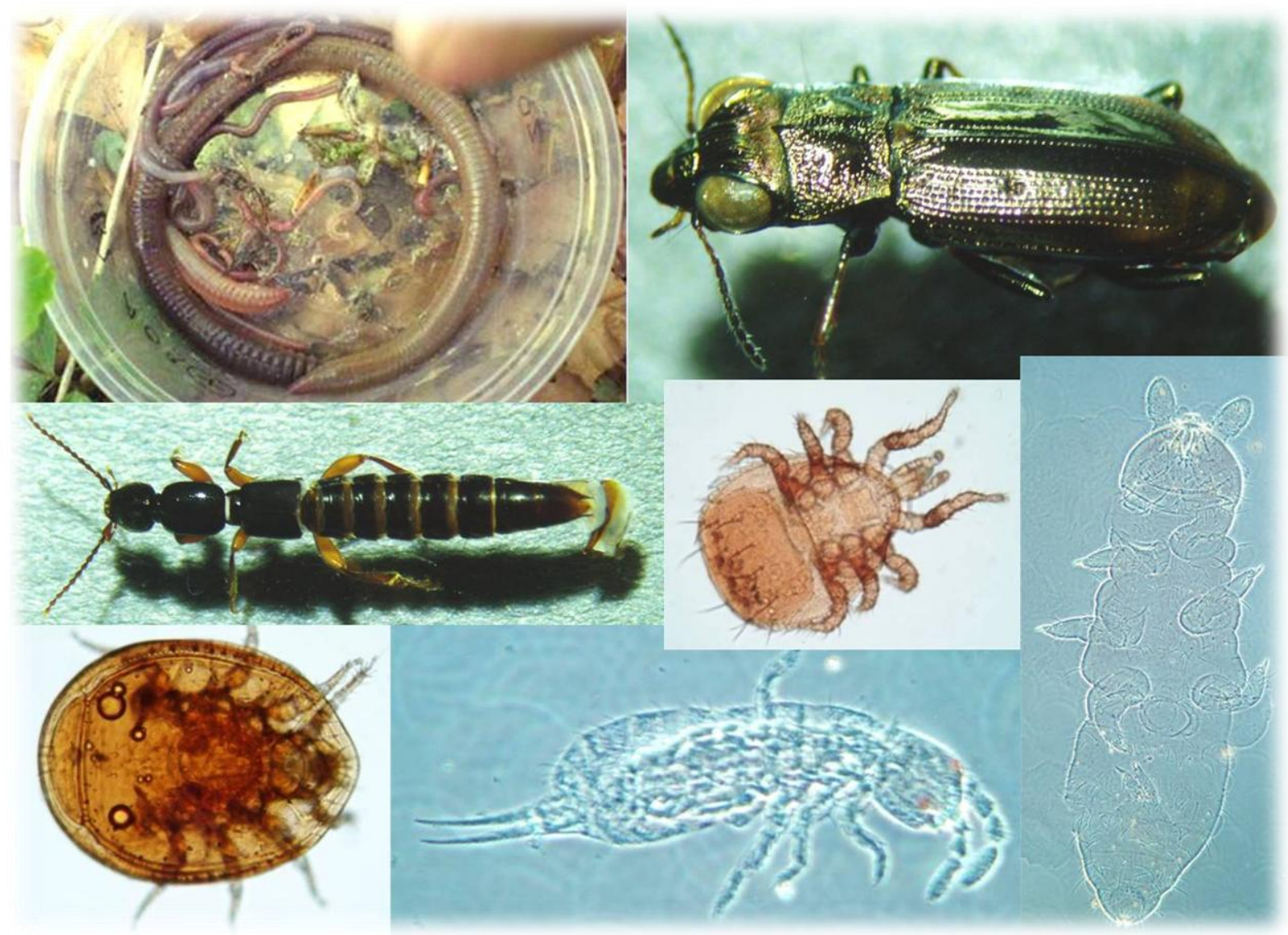


Table A1. Mean values $( \pm$ SD) of environmental variables in different regions (Alb $=$ Swabian Alb, Hai $=$ Hainich, Sch $=$ Schorfheide $)$ and forest types $($ Conif $=$ coniferous forest, $\mathrm{B} 30=$ young managed beech, $\mathrm{B} 70=$ old managed beech, unm $\mathrm{B}=$ unmanaged beech); for units refer to section 2.3.

\begin{tabular}{|c|c|c|c|c|c|c|c|c|}
\hline Factorlevel & $\mathrm{N}$ & Amount of leaf litter & Soil Cmic & Leaf litter Cmic & Soil pH & Leaf litter $\mathrm{C} / \mathrm{N}$ & Fine root $\mathrm{C} / \mathrm{N}$ & Soil C/N \\
\hline$\overline{\text { Total }}$ & 48 & $0.57 \pm 0.31$ & $824.98 \pm 511.24$ & $7461.46 \pm 3055.06$ & $4.15 \pm 0.82$ & $32.61 \pm 5.51$ & $33.56 \pm 4.81$ & $15.82 \pm 2.93$ \\
\hline Alb & 16 & $0.72 \pm 0.26$ & $1109.53 \pm 468.41$ & $8568.89 \pm 2864.33$ & $4.53 \pm 0.71$ & $31.69 \pm 3.52$ & $35.11 \pm 5.57$ & $14.41 \pm 1.98$ \\
\hline Hai & 16 & $0.45 \pm 0.30$ & $1016.02 \pm 473.09$ & $6330.73 \pm 2824.69$ & $4.61 \pm 0.67$ & $31.23 \pm 3.97$ & $32.06 \pm 4.18$ & $14.85 \pm 2.35$ \\
\hline Sch & 16 & $0.56 \pm 0.32$ & $349.40 \pm 95.76$ & $7484.76 \pm 3223.16$ & $3.32 \pm 0.20$ & $34.91 \pm 7.65$ & $33.51 \pm 4.34$ & $18.20 \pm 2.86$ \\
\hline Conif & 12 & $0.79 \pm 0.37$ & $599.03 \pm 437.60$ & $5105.13 \pm 2680.39$ & $3.78 \pm 0.84$ & $33.44 \pm 9.50$ & $36.53 \pm 5.56$ & $17.93 \pm 3.46$ \\
\hline B30 & 12 & $0.62 \pm 0.33$ & $934.04 \pm 504.53$ & $7627.39 \pm 2753.16$ & $4.45 \pm 0.82$ & $30.89 \pm 3.53$ & $33.17 \pm 3.62$ & $15.31 \pm 2.93$ \\
\hline B70 & 12 & $0.45 \pm 0.17$ & $850.86 \pm 501.72$ & $7349.19 \pm 2636.65$ & $4.28 \pm 0.88$ & $32.32 \pm 2.80$ & $32.50 \pm 3.21$ & $14.36 \pm 2.12$ \\
\hline unm B & 12 & $0.44 \pm 0.22$ & $916.00 \pm 583.55$ & $9764.12 \pm 2505.50$ & $4.10 \pm 0.66$ & $33.78 \pm 3.70$ & $32.03 \pm 5.56$ & $15.69 \pm 2.00$ \\
\hline Alb, Conif & 4 & $0.79 \pm 0.34$ & $613.70 \pm 245.09$ & $5895.74 \pm 2321.71$ & $3.75 \pm 0.54$ & $29.03 \pm 1.70$ & $38.38 \pm 7.97$ & $16.35 \pm 1.53$ \\
\hline Alb, B30 & 4 & $0.92 \pm 0.22$ & $1161.91 \pm 109.49$ & $7819.44 \pm 1185.05$ & $5.00 \pm 0.35$ & $30.08 \pm 3.25$ & $35.13 \pm 4.10$ & $13.95 \pm 2.44$ \\
\hline Alb, B70 & 4 & $0.63 \pm 0.03$ & $1258.42 \pm 604.22$ & $8129.34 \pm 1762.11$ & $4.75 \pm 0.77$ & $33.05 \pm 3.27$ & $33.48 \pm 4.38$ & $12.93 \pm 1.45$ \\
\hline Alb, unm B & 4 & $0.52 \pm 0.23$ & $1404.08 \pm 428.02$ & $12431.04 \pm 836.54$ & $4.60 \pm 0.55$ & $34.60 \pm 3.32$ & $33.45 \pm 5.87$ & $14.43 \pm 1.02$ \\
\hline Hai, Conif & 4 & $0.65 \pm 0.46$ & $864.97 \pm 655.67$ & $4813.02 \pm 3428.65$ & $4.43 \pm 1.08$ & $27.53 \pm 5.61$ & $35.63 \pm 3.53$ & $15.53 \pm 2.50$ \\
\hline Hai, B30 & 4 & $0.31 \pm 0.18$ & $1346.15 \pm 274.69$ & $7249.71 \pm 3927.80$ & $4.93 \pm 0.43$ & $32.03 \pm 3.39$ & $32.68 \pm 3.83$ & $15.15 \pm 3.44$ \\
\hline Hai, B70 & 4 & $0.38 \pm 0.14$ & $899.84 \pm 228.86$ & $5939.19 \pm 2375.13$ & $4.78 \pm 0.55$ & $33.40 \pm 2.54$ & $31.83 \pm 3.25$ & $13.83 \pm 1.73$ \\
\hline Hai, unm B & 4 & $0.47 \pm 0.29$ & $953.13 \pm 601.94$ & $7321.02 \pm 1166.51$ & $4.30 \pm 0.47$ & $31.98 \pm 1.78$ & $28.10 \pm 3.38$ & $14.90 \pm 2.09$ \\
\hline Sch, Conif & 4 & $0.93 \pm 0.34$ & $318.44 \pm 112.30$ & $4606.64 \pm 2814.00$ & $3.15 \pm 0.24$ & $43.78 \pm 9.04$ & $35.60 \pm 5.52$ & $21.90 \pm 1.83$ \\
\hline Sch, B30 & 4 & $0.62 \pm 0.26$ & $294.06 \pm 64.32$ & $7813.03 \pm 3267.38$ & $3.43 \pm 0.17$ & $30.58 \pm 4.59$ & $31.70 \pm 2.86$ & $16.83 \pm 2.86$ \\
\hline Sch, B70 & 4 & $0.34 \pm 0.11$ & $394.32 \pm 54.38$ & $7979.06 \pm 3571.10$ & $3.30 \pm 0.14$ & $30.50 \pm 2.20$ & $32.20 \pm 2.46$ & $16.33 \pm 1.76$ \\
\hline Sch, unm B & 4 & $0.35 \pm 0.14$ & $390.79 \pm 125.72$ & $9540.31 \pm 1857.06$ & $3.40 \pm 0.16$ & $34.78 \pm 5.44$ & $34.55 \pm 5.96$ & $17.75 \pm 0.79$ \\
\hline
\end{tabular}


Table A2. Number of species (spp. $\mathrm{m}^{-2}$, mean \pm SD) of soil animal functional groups in different regions and forest types; for legend see Table A1).

\begin{tabular}{|c|c|c|c|c|c|c|}
\hline Factorlevel & $\mathrm{N}$ & Macrofauna decomposers & Macrofauna herbivores & Macrofauna predators & Mesofauna decomposers & Mesofauna predators \\
\hline Total & 48 & $9.60 \pm 5.61$ & $2.83 \pm 1.59$ & $18.75 \pm 5.06$ & $23.65 \pm 4.81$ & $16.60 \pm 4.29$ \\
\hline Alb & 16 & $10.75 \pm 4.14$ & $3.06 \pm 1.77$ & $18.88 \pm 4.00$ & $24.19 \pm 5.04$ & $16.81 \pm 3.58$ \\
\hline Hai & 16 & $14.19 \pm 3.64$ & $3.00 \pm 1.41$ & $21.31 \pm 4.74$ & $22.44 \pm 4.24$ & $17.81 \pm 5.75$ \\
\hline Sch & 16 & $3.88 \pm 3.10$ & $2.44 \pm 1.59$ & $16.06 \pm 5.18$ & $24.31 \pm 5.19$ & $15.19 \pm 2.81$ \\
\hline Conif & 12 & $7.67 \pm 6.44$ & $2.67 \pm 1.30$ & $17.92 \pm 4.14$ & $26.67 \pm 5.61$ & $16.58 \pm 2.61$ \\
\hline B30 & 12 & $11.08 \pm 4.60$ & $2.83 \pm 1.75$ & $19.17 \pm 5.24$ & $23.67 \pm 4.83$ & $18.58 \pm 4.21$ \\
\hline B70 & 12 & $10.00 \pm 6.37$ & $1.92 \pm 1.08$ & $17.00 \pm 6.22$ & $22.67 \pm 3.58$ & $16.00 \pm 5.49$ \\
\hline unm B & 12 & $9.67 \pm 4.98$ & $3.92 \pm 1.62$ & $20.92 \pm 4.06$ & $21.58 \pm 3.96$ & $15.25 \pm 4.14$ \\
\hline Alb, Conif & 4 & $5.75 \pm 2.87$ & $2.50 \pm 1.29$ & $20.00 \pm 2.94$ & $31.25 \pm 3.77$ & $18.50 \pm 3.51$ \\
\hline Alb, B30 & 4 & $12.75 \pm 1.50$ & $3.00 \pm 1.83$ & $18.50 \pm 5.74$ & $21.00 \pm 1.41$ & $17.50 \pm 3.42$ \\
\hline Alb, B70 & 4 & $12.00 \pm 5.35$ & $1.75 \pm 1.26$ & $16.00 \pm 2.58$ & $21.50 \pm 4.12$ & $14.00 \pm 4.24$ \\
\hline Alb, unm B & 4 & $12.50 \pm 1.29$ & $5.00 \pm 1.15$ & $21.00 \pm 3.56$ & $23.00 \pm 1.41$ & $17.25 \pm 2.63$ \\
\hline Hai, Conif & 4 & $15.50 \pm 3.11$ & $3.25 \pm 0.96$ & $17.75 \pm 1.71$ & $20.75 \pm 3.40$ & $15.25 \pm 1.71$ \\
\hline Hai, B30 & 4 & $14.25 \pm 3.77$ & $3.75 \pm 1.71$ & $22.50 \pm 5.74$ & $24.25 \pm 5.74$ & $21.00 \pm 5.60$ \\
\hline Hai, B70 & 4 & $14.75 \pm 3.95$ & $1.75 \pm 0.96$ & $23.00 \pm 5.83$ & $22.25 \pm 1.50$ & $20.75 \pm 6.75$ \\
\hline Hai, unm B & 4 & $12.25 \pm 4.35$ & $3.25 \pm 1.50$ & $22.00 \pm 4.40$ & $22.50 \pm 5.92$ & $14.25 \pm 5.91$ \\
\hline Sch, Conif & 4 & $1.75 \pm 0.96$ & $2.25 \pm 1.71$ & $16.00 \pm 6.38$ & $28.00 \pm 3.56$ & $16.00 \pm 1.41$ \\
\hline Sch, B30 & 4 & $6.25 \pm 3.59$ & $1.75 \pm 1.50$ & $16.50 \pm 3.11$ & $25.75 \pm 5.91$ & $17.25 \pm 3.20$ \\
\hline Sch, B70 & 4 & $3.25 \pm 2.87$ & $2.25 \pm 1.26$ & $12.00 \pm 4.32$ & $24.25 \pm 4.72$ & $13.25 \pm 1.26$ \\
\hline Sch, unm B & 4 & $4.25 \pm 3.40$ & $3.50 \pm 1.91$ & $19.75 \pm 4.99$ & $19.25 \pm 3.10$ & $14.25 \pm 3.59$ \\
\hline
\end{tabular}


Table A3. Abundances (Ind. $\mathrm{m}^{-2}$, mean \pm SD) of soil animal functional groups in different regions and forest types; for legend see Table A1).

\begin{tabular}{|c|c|c|c|c|c|c|}
\hline Factorlevel & $\mathrm{N}$ & Macrofauna decomposers & Macrofauna herbivores & Macrofauna predators & Mesofauna decomposers & Mesofauna predators \\
\hline Total & 48 & $690.67 \pm 606.34$ & $156.52 \pm 123.40$ & $867.06 \pm 377.14$ & $87234.38 \pm 57740.73$ & $40742.31 \pm 33548.46$ \\
\hline Alb & 16 & $877.75 \pm 661.07$ & $147.75 \pm 98.95$ & $856.50 \pm 418.73$ & $76232.13 \pm 44959.06$ & $41924.69 \pm 24823.13$ \\
\hline Hai & 16 & $970.44 \pm 507.17$ & $183.31 \pm 158.27$ & $938.19 \pm 384.13$ & $71907.94 \pm 64163.84$ & $33284.06 \pm 36739.91$ \\
\hline Sch & 16 & $223.81 \pm 323.14$ & $138.50 \pm 108.06$ & $806.50 \pm 336.68$ & $113563.06 \pm 56472.12$ & $47018.19 \pm 38180.06$ \\
\hline Conif & 12 & $594.17 \pm 494.72$ & $204.58 \pm 169.75$ & $793.08 \pm 385.07$ & $145731.58 \pm 67337.42$ & $56774.08 \pm 41926.77$ \\
\hline B30 & 12 & $549.42 \pm 340.38$ & $100.42 \pm 89.59$ & $762.75 \pm 303.08$ & $79540.17 \pm 45865.67$ & $41369.75 \pm 20283.24$ \\
\hline B70 & 12 & $849.08 \pm 892.40$ & $135.50 \pm 91.72$ & $855.50 \pm 425.89$ & $65753.17 \pm 43811.42$ & $37937.50 \pm 43993.18$ \\
\hline unm B & 12 & $770.00 \pm 589.67$ & $185.58 \pm 111.58$ & $1056.92 \pm 359.03$ & $57912.58 \pm 21187.25$ & $26887.92 \pm 14335.18$ \\
\hline Alb, Conif & 4 & $489.50 \pm 250.39$ & $168.00 \pm 94.73$ & $840.50 \pm 430.17$ & $136359.00 \pm 42695.28$ & $66069.00 \pm 27871.30$ \\
\hline Alb, B30 & 4 & $747.00 \pm 426.23$ & $93.25 \pm 87.54$ & $548.75 \pm 347.78$ & $51099.75 \pm 31937.38$ & $37336.00 \pm 22332.68$ \\
\hline Alb, B70 & 4 & $1175.75 \pm 1087.91$ & $109.75 \pm 73.92$ & $714.00 \pm 301.50$ & $47408.00 \pm 17138.64$ & $25591.25 \pm 22468.82$ \\
\hline Alb, unm B & 4 & $1098.75 \pm 591.51$ & $220.00 \pm 116.04$ & $1322.75 \pm 190.31$ & $70061.75 \pm 12203.51$ & $38702.50 \pm 11209.11$ \\
\hline Hai, Conif & 4 & $1093.25 \pm 501.65$ & $246.00 \pm 245.74$ & $815.00 \pm 254.10$ & $132729.25 \pm 103829.77$ & $54597.50 \pm 70367.25$ \\
\hline Hai, B30 & 4 & $587.50 \pm 111.42$ & $142.00 \pm 122.25$ & $852.25 \pm 304.53$ & $67578.00 \pm 44857.38$ & $34685.00 \pm 19173.75$ \\
\hline Hai, B70 & 4 & $1316.00 \pm 678.39$ & $169.50 \pm 113.76$ & $1151.50 \pm 555.56$ & $45626.75 \pm 11242.61$ & $27876.00 \pm 15551.62$ \\
\hline Hai, unm B & 4 & $885.00 \pm 421.02$ & $175.75 \pm 170.68$ & $934.00 \pm 425.50$ & $41697.75 \pm 23888.74$ & $15977.75 \pm 11892.28$ \\
\hline Sch, Conif & 4 & $199.75 \pm 170.07$ & $199.75 \pm 179.41$ & $723.75 \pm 532.93$ & $168106.50 \pm 54884.48$ & $49655.75 \pm 22978.99$ \\
\hline Sch, B30 & 4 & $313.75 \pm 320.46$ & $66.00 \pm 53.59$ & $887.25 \pm 175.27$ & $119942.75 \pm 35149.35$ & $52088.25 \pm 20190.70$ \\
\hline Sch, B70 & 4 & $55.50 \pm 60.42$ & $127.25 \pm 99.63$ & $701.00 \pm 300.27$ & $104224.75 \pm 60461.39$ & $60345.25 \pm 73089.48$ \\
\hline Sch, unm B & 4 & $326.25 \pm 568.79$ & $161.00 \pm 23.27$ & $914.00 \pm 337.32$ & $61978.25 \pm 18893.48$ & $25983.50 \pm 11853.58$ \\
\hline
\end{tabular}


Table A4. Population biomass ( $\mathrm{g} \mathrm{m}^{-2}$, mean $\pm \mathrm{SD}$ ) of soil animal functional groups in different regions and forest types; for legend see Table A1).

\begin{tabular}{|c|c|c|c|c|c|c|}
\hline Factorlevel & $\mathrm{N}$ & Macrofauna decomposers & Macrofauna herbivores & Macrofauna predators & Mesofauna decomposers & Mesofauna predators \\
\hline Total & 48 & $23677.54 \pm 26214.08$ & $609.11 \pm 608.5$ & $4520.28 \pm 3981.81$ & $1269.03 \pm 802.96$ & $566.92 \pm 396.03$ \\
\hline Alb & 16 & $27087.21 \pm 23991.06$ & $560.07 \pm 576.71$ & $3699.52 \pm 2585.93$ & $1163.47 \pm 704.29$ & $691.19 \pm 535.06$ \\
\hline Hai & 16 & $40590.26 \pm 28364.88$ & $770.21 \pm 546.94$ & $5107.91 \pm 4298.28$ & $916.68 \pm 457.39$ & $465.22 \pm 362.33$ \\
\hline Sch & 16 & $3355.16 \pm 3870.23$ & $497.05 \pm 696.27$ & $4753.41 \pm 4834.40$ & $1726.94 \pm 973.15$ & $544.36 \pm 214.02$ \\
\hline Conif & 12 & $23015.95 \pm 37896.05$ & $904.03 \pm 985.44$ & $2450.50 \pm 1255.15$ & $1989.64 \pm 1136.48$ & $721.76 \pm 450.06$ \\
\hline B30 & 12 & $19703.45 \pm 16310.67$ & $404.63 \pm 396.30$ & $4287.04 \pm 2586.53$ & $1161.94 \pm 612.09$ & $649.09 \pm 548.69$ \\
\hline B70 & 12 & $24696.44 \pm 20260.94$ & $449.01 \pm 296.06$ & $4661.96 \pm 3216.57$ & $1024.35 \pm 469.54$ & $466.76 \pm 267.23$ \\
\hline unm B & 12 & $27294.34 \pm 28113.36$ & $678.79 \pm 438.75$ & $6681.61 \pm 6267.44$ & $900.21 \pm 274.68$ & $430.08 \pm 173.82$ \\
\hline Alb, Conif & 4 & $5164.56 \pm 5960.56$ & $879.10 \pm 1000.41$ & $2387.73 \pm 1114.42$ & $2141.78 \pm 463.59$ & $994.04 \pm 357.78$ \\
\hline Alb, B30 & 4 & $30070.09 \pm 17551.96$ & $432.48 \pm 454.43$ & $2676.97 \pm 1254.89$ & $782.80 \pm 538.25$ & $868.22 \pm 948.19$ \\
\hline Alb, B70 & 4 & $32457.53 \pm 29258.30$ & $410.61 \pm 368.18$ & $3766.55 \pm 1753.32$ & $821.60 \pm 439.94$ & $388.73 \pm 255.97$ \\
\hline Alb, unm B & 4 & $40656.66 \pm 27231.96$ & $518.10 \pm 361.32$ & $5966.84 \pm 4122.55$ & $907.71 \pm 263.74$ & $513.77 \pm 104.13$ \\
\hline Hai, Conif & 4 & $63712.71 \pm 43601.87$ & $890.05 \pm 829.84$ & $1857.90 \pm 200.54$ & $1048.95 \pm 744.63$ & $598.05 \pm 648.04$ \\
\hline Hai, B30 & 4 & $26853.75 \pm 6530.56$ & $601.79 \pm 481.53$ & $5007.00 \pm 2695.47$ & $967.87 \pm 447.21$ & $501.14 \pm 269.29$ \\
\hline Hai, B70 & 4 & $33034.34 \pm 10899.90$ & $556.71 \pm 265.24$ & $6880.89 \pm 4346.24$ & $868.46 \pm 384.41$ & $433.49 \pm 241.56$ \\
\hline Hai, unm B & 4 & $38760.24 \pm 30252.49$ & $1032.30 \pm 543.60$ & $6685.83 \pm 6676.26$ & $781.45 \pm 299.14$ & $328.20 \pm 232.3$ \\
\hline Sch, Conif & 4 & $170.57 \pm 94.97$ & $942.93 \pm 1366.78$ & $3105.87 \pm 1856.91$ & $2778.18 \pm 1388.03$ & $573.18 \pm 214.57$ \\
\hline Sch, B30 & 4 & $2186.52 \pm 2042.11$ & $179.62 \pm 130.81$ & $5177.16 \pm 3238.24$ & $1735.15 \pm 451.68$ & $577.91 \pm 179.85$ \\
\hline Sch, B70 & 4 & $8597.45 \pm 3428.56$ & $379.69 \pm 302.73$ & $3338.44 \pm 2450.11$ & $1382.99 \pm 456.46$ & $578.07 \pm 334.44$ \\
\hline Sch, unm B & 4 & $2466.13 \pm 2433.14$ & $485.97 \pm 170.75$ & $7392.17 \pm 9005.96$ & $1011.45 \pm 286.76$ & $448.27 \pm 149.51$ \\
\hline
\end{tabular}


Table A5. List of species ordered by taxonomic group including affiliation to family and functional group

\begin{tabular}{|c|c|c|c|}
\hline Taxonomic group & Species & Family & Functional group \\
\hline Araneae & Agroeca cf brunnea & Liocranidae & Macrofauna predators \\
\hline Araneae & Amaurobius fenestralis & Amaurobiidae & Macrofauna predators \\
\hline Araneae & Anyphaena accentuata & Anyphaenidae & Macrofauna predators \\
\hline Araneae & Apostenus fuscus & Liocranidae & Macrofauna predators \\
\hline Araneae & Araniella cucurbitina & Araneidae & Macrofauna predators \\
\hline Araneae & Asthenargus paganus & Linyphiidae & Macrofauna predators \\
\hline Araneae & Ballus chalybeius & Salticidae & Macrofauna predators \\
\hline Araneae & Bathyphantes gracilis & Linyphiidae & Macrofauna predators \\
\hline Araneae & Callobius claustrarius & Amaurobiidae & Macrofauna predators \\
\hline Araneae & Centromerus brevivulvatus & Linyphiidae & Macrofauna predators \\
\hline Araneae & Centromerus cavernarum & Linyphiidae & Macrofauna predators \\
\hline Araneae & Centromerus prudens & Linyphiidae & Macrofauna predators \\
\hline Araneae & Centromerus serratus & Linyphiidae & Macrofauna predators \\
\hline Araneae & Centromerus sylvaticus & Linyphiidae & Macrofauna predators \\
\hline Araneae & Ceratinella brevis & Linyphiidae & Macrofauna predators \\
\hline Araneae & Ceratinella scabrosa & Linyphiidae & Macrofauna predators \\
\hline Araneae & Clubiona comta & Clubionidae & Macrofauna predators \\
\hline Araneae & Clubiona pallidula & Clubionidae & Macrofauna predators \\
\hline Araneae & Coelotes terrestris & Amaurobiidae & Macrofauna predators \\
\hline Araneae & Dictyna latens & Dictynidae & Macrofauna predators \\
\hline Araneae & Dicymbium brevisetosum & Linyphiidae & Macrofauna predators \\
\hline Araneae & Diplocephalus latifrons & Linyphiidae & Macrofauna predators \\
\hline Araneae & Diplocephalus picinus & Linyphiidae & Macrofauna predators \\
\hline Araneae & Diplostyla concolor & Linyphiidae & Macrofauna predators \\
\hline Araneae & Donacochara speciosa & Linyphiidae & Macrofauna predators \\
\hline Araneae & Enoplognatha ovata & Theridiidae & Macrofauna predators \\
\hline Araneae & Erigonella hiemalis & Linyphiidae & Macrofauna predators \\
\hline Araneae & Ero furcata & Mimetidae & Macrofauna predators \\
\hline Araneae & Euophrys frontalis & Salticidae & Macrofauna predators \\
\hline Araneae & Euophrys herbigrada & Salticidae & Macrofauna predators \\
\hline Araneae & Eurocoelotes inermis & Amaurobiidae & Macrofauna predators \\
\hline Araneae & Euryopis flavomaculata & Theridiidae & Macrofauna predators \\
\hline Araneae & Evarcha arcuata & Salticidae & Macrofauna predators \\
\hline Araneae & Gonatium rubens & Linyphiidae & Macrofauna predators \\
\hline Araneae & Gongylidiellum latebricola & Linyphiidae & Macrofauna predators \\
\hline Araneae & Hahnia pusilla & Hahniidae & Macrofauna predators \\
\hline Araneae & Haplodrassus silvestris & Gnaphosidae & Macrofauna predators \\
\hline Araneae & Haplodrassus soerenseni & Gnaphosidae & Macrofauna predators \\
\hline Araneae & Harpactea lepida & Dysderidae & Macrofauna predators \\
\hline Araneae & Histopona torpida & Agelenidae & Macrofauna predators \\
\hline Araneae & Linyphia hortensis & Linyphiidae & Macrofauna predators \\
\hline Araneae & Macrargus rufus & Linyphiidae & Macrofauna predators \\
\hline Araneae & Maro minutus & Linyphiidae & Macrofauna predators \\
\hline Araneae & Metellina segmentata & Tetragnathidae & Macrofauna predators \\
\hline Araneae & Micrargus herbigradus & Linyphiidae & Macrofauna predators \\
\hline Araneae & Microlinyphia pusilla & Linyphiidae & Macrofauna predators \\
\hline Araneae & Microneta viaria & Linyphiidae & Macrofauna predators \\
\hline Araneae & Monocephalus fuscipes & Linyphiidae & Macrofauna predators \\
\hline Araneae & Neon reticulatus & Salticidae & Macrofauna predators \\
\hline Araneae & Ozyptila particola & Thomisidae & Macrofauna predators \\
\hline Araneae & Ozyptila trux & Thomisidae & Macrofauna predators \\
\hline Araneae & Pachygnatha degeeri & Tetragnathidae & Macrofauna predators \\
\hline
\end{tabular}


Taxonomic group Species

Araneae

Araneae

Araneae

Araneae

Araneae

Araneae

Araneae

Araneae

Araneae

Araneae

Araneae

Araneae

Araneae

Araneae

Araneae

Araneae

Araneae

Araneae

Araneae

Araneae

Araneae

Araneae

Araneae

Araneae

Araneae

Araneae

Araneae

Araneae

Araneae

Araneae

Chilopoda

Chilopoda

Chilopoda

Chilopoda

Chilopoda

Chilopoda

Chilopoda

Chilopoda

Chilopoda

Chilopoda

Chilopoda

Chilopoda

Chilopoda

Chilopoda

Chilopoda

Chilopoda

Chilopoda

Chilopoda

Chilopoda

Chilopoda

Chilopoda

Chilopoda

Chilopoda

Chilopoda
Palliduphantes pallidus

Pardosa lugubris

Pelecopsis radicicola

Philodromus dispar

Pocadicnemis juncea

Porrhomma microphthalmum

Robertus lividus

Robertus scoticus

Saaristoa abnormis

Saloca diceros

Tapinocyba insecta

Tapinocyba pallens

Tapinocyba praecox

Tenuiphantes flavipes

Tenuiphantes mengei

Tenuiphantes tenebricola

Tenuiphantes tenuis

Troxochrus nasutus

Walckenaeria antica

Walckenaeria atrotibialis

Walckenaeria corniculans

Walckenaeria cucullata

Walckenaeria cuspidata

Walckenaeria dysderoides

Walckenaeria furcillata

Walckenaeria nudipalpis

Xysticus cristatus

Xysticus erraticus

Xysticus lanio

Zora spinimana

Cryptops hortensis

Geophilus electricus

Geophilus flavus

Geophilus insculptus

Geophilus ribauti

Geophilus studeri

Geophilus truncorum

Lithobius aeruginosus

Lithobius aulacopus

Lithobius calcaratus

Lithobius crassipes

Lithobius curtipes

Lithobius dentatus

Lithobius erythrocephalus

Lithobius forficatus

Lithobius lapidicola

Lithobius melanops

Lithobius mutabilis

Lithobius muticus

Lithobius piceus

Lithobius subtilis

Lithobius tricuspis

Schendyla nemorensis

Strigamia acuminata

Family

Functional group

Linyphiidae

Lycosidae

Linyphiidae

Philodromidae

Linyphiidae

Linyphiidae

Theridiidae

Theridiidae

Linyphiidae

Linyphiidae

Linyphiidae

Linyphiidae

Linyphiidae

Linyphiidae

Linyphiidae

Linyphiidae

Linyphiidae

Linyphiidae

Linyphiidae

Linyphiidae

Linyphiidae

Linyphiidae

Linyphiidae

Linyphiidae

Linyphiidae

Linyphiidae

Thomisidae

Thomisidae

Thomisidae

Zordae

Cryptopidae

Geophilidae

Geophilidae

Geophilidae

Geophilidae

Geophilidae

Geophilidae

Lithobiidae

Lithobiidae

Lithobiidae

Lithobiidae

Lithobiidae

Lithobiidae

Lithobiidae

Lithobiidae

Lithobiidae

Lithobiidae

Lithobiidae

Lithobiidae

Lithobiidae

Lithobiidae

Lithobiidae

Schendylidae

Dignathodontidae
Macrofauna predators

Macrofauna predators

Macrofauna predators

Macrofauna predators

Macrofauna predators

Macrofauna predators

Macrofauna predators

Macrofauna predators

Macrofauna predators

Macrofauna predators

Macrofauna predators

Macrofauna predators

Macrofauna predators

Macrofauna predators

Macrofauna predators

Macrofauna predators

Macrofauna predators

Macrofauna predators

Macrofauna predators

Macrofauna predators

Macrofauna predators

Macrofauna predators

Macrofauna predators

Macrofauna predators

Macrofauna predators

Macrofauna predators

Macrofauna predators

Macrofauna predators

Macrofauna predators

Macrofauna predators

Macrofauna predators

Macrofauna predators

Macrofauna predators

Macrofauna predators

Macrofauna predators

Macrofauna predators

Macrofauna predators

Macrofauna predators

Macrofauna predators

Macrofauna predators

Macrofauna predators

Macrofauna predators

Macrofauna predators

Macrofauna predators

Macrofauna predators

Macrofauna predators

Macrofauna predators

Macrofauna predators

Macrofauna predators

Macrofauna predators

Macrofauna predators

Macrofauna predators

Macrofauna predators

Macrofauna predators 
Taxonomic group Species

Coleoptera

Coleoptera

Coleoptera

Coleoptera

Coleoptera

Coleoptera

Coleoptera

Coleoptera

Coleoptera

Coleoptera

Coleoptera

Coleoptera

Coleoptera

Coleoptera

Coleoptera

Coleoptera

Coleoptera

Coleoptera

Coleoptera

Coleoptera

Coleoptera

Coleoptera

Coleoptera

Coleoptera

Coleoptera

Coleoptera

Coleoptera

Coleoptera

Coleoptera

Coleoptera

Coleoptera

Coleoptera

Coleoptera

Coleoptera

Coleoptera

Coleoptera

Coleoptera

Coleoptera

Coleoptera

Coleoptera

Coleoptera

Coleoptera

Coleoptera

Coleoptera

Coleoptera

Coleoptera

Coleoptera

Coleoptera

Coleoptera

Coleoptera

Coleoptera

Coleoptera

Coleoptera

Coleoptera
Abax ovalis

Abax parallelepipedus

Abax parallelus

Acrotona sylvicola

Agonum sexpunctatum

Agriotes acuminatus

Agriotes aterrimus

Agriotinae sp1

Aleocharinae sp1

Aleocharinae sp2

Amara aenea

Anatis ocellata

Anthicus flavipes

Anthicus floralis

Atheta fungi

Atheta myrmecobia

Athous haemorrhoidalis

Athous mollis

Athous subfuscus

Athous vittatus

Athous zebei

Byrrhidae sp1

Bythinus acutangulus

Calathus melanocephalus

Carabus nemoralis

Coccinella septempunctata

Conosoma testaceum

Crychus caraboides

Cryptorhynchinae sp1

Cychrus attenuatus

Dalopius marginatus

Domene scabricollis

Elater ferrugineus

Geostiba circellaris

Habrocerus capillaricornis

Harpalus affinis

Harpalus latus

Heterothops dissimilis

Histeridae sp1

Lamprohiza splendidula

Lathrobium brunnipes

Liogluta longiuscula

Luperus luperus

Malthinus seriepunctatus

Microlestes minutulus

Molops elatus

Molops piceus

Mycetoporus mulsanti

Nargus anisotomoides

Nargus wilkini

Neobisius villosulus

Notiophilus biguttatus

Notiophilus rufipes

Olophrum piceum
Family

Functional group

Carabidae

Carabidae

Carabidae

Stapylinidae

Carabidae

Elateridae

Elateridae

Elateridae

Stapylinidae

Stapylinidae

Carabidae

Coccinelidae

Anthicidae

Anthicidae

Stapylinidae

Stapylinidae

Elateridae

Elateridae

Elateridae

Elateridae

Elateridae

Byrrhidae

Pselaphidae

Carabidae

Carabidae

Coccinellidae

Stapylinidae

Carabidae

Curculionidae

Carabidae

Elateridae

Stapylinidae

Elateridae

Stapylinidae

Stapylinidae

Carabidae

Carabidae

Stapylinidae

Histeridae

Lampyridae

Stapylinidae

Stapylinidae

Chrysomelidae

Cantharidae

Carabidae

Carabidae

Carabidae

Stapylinidae

Catopidae

Catopidae

Stapylinidae

Carabidae

Carabidae

Stapylinidae
Macrofauna predators

Macrofauna predators

Macrofauna predators

Macrofauna predators

Macrofauna predators

Macrofauna herbivores

Macrofauna herbivores

Macrofauna herbivores

Macrofauna predators

Macrofauna predators

Macrofauna predators

Macrofauna predators

Macrofauna decomposers

Macrofauna decomposers

Macrofauna predators

Macrofauna predators

Macrofauna herbivores

Macrofauna herbivores

Macrofauna herbivores

Macrofauna herbivores

Macrofauna herbivores

Macrofauna herbivores

Macrofauna predators

Macrofauna predators

Macrofauna predators

Macrofauna predators

Macrofauna predators

Macrofauna predators

Macrofauna herbivores

Macrofauna predators

Macrofauna herbivores

Macrofauna predators

Macrofauna herbivores

Macrofauna predators

Macrofauna predators

Macrofauna predators

Macrofauna predators

Macrofauna predators

Macrofauna predators

Macrofauna predators

Macrofauna predators

Macrofauna predators

Macrofauna herbivores

Macrofauna predators

Macrofauna predators

Macrofauna predators

Macrofauna predators

Macrofauna predators

Macrofauna decomposers

Macrofauna decomposers

Macrofauna predators

Macrofauna predators

Macrofauna predators

Macrofauna predators 
Taxonomic group Species Family

Coleoptera

Coleoptera

Coleoptera

Coleoptera

Coleoptera

Coleoptera

Coleoptera

Coleoptera

Coleoptera

Coleoptera

Coleoptera

Coleoptera

Coleoptera

Coleoptera

Coleoptera

Coleoptera

Coleoptera

Coleoptera

Coleoptera

Coleoptera

Coleoptera

Coleoptera

Coleoptera

Coleoptera

Coleoptera

Coleoptera

Coleoptera

Coleoptera

Coleoptera

Coleoptera

Coleoptera

Coleoptera

Coleoptera

Coleoptera

Coleoptera

Coleoptera

Collembola

Collembola

Collembola

Collembola

Collembola

Collembola

Collembola

Collembola

Collembola

Collembola

Collembola

Collembola

Collembola

Collembola

Collembola

Collembola

Collembola

Collembola
Oodes helipioides

Othius punctulatus

Othius subuliformis

Oxypoda annularis

Pamagaeus bipustulatus

Philonthus carbonarius

Phyllobius callacartus

Phyllobius oblongus

Phyllobius pyri

Plectophoreus fischeri

Pterostichus burmeisteri

Pterostichus chamaeleon

Pterostichus longicollis

Pterostichus oblongopunctatus

Pterostichus strenuus

Rhagonycha lignosa

Rhagonycha limbata

Rhynchaeninae sp1

Rhynchaenus fagi

Scydmaenidae sp1

Scydmaenidae sp2

Staphylinidae sp1

Stenus clavicornis

Stenus fuscicornis

Stenus humilis

Stenus impressus

Stenus mendicus

Stilicus rufipes

Synuchus nivalis

Tachinus scapularis

Tachyporus obtusus

Tenebrionidae sp1

Trechus nigrinus

Trimium brevicorne

Xantholinus laevigatus

Xantholinus tricolor

Allacma fusca

Arrhopalites pygmaeus

Ballistura cf hankoi

Brachystomella parvula

Ceratophysella armata

Ceratophysella denticulata

Ceratophysella gibbosa

Ceratophysella succinea

Cryptopygus garretti

Desoria violacea

Deuteraphorura inermis

Deuterosminthurus pallipes

Dicyrtoma fusca

Dicyrtomina ornata

Entomobrya cf marginata

Entomobrya cf multifasciata

Entomobrya corticalis

Entomobrya quinquelineata
Carabidae

Stapylinidae

Stapylinidae

Stapylinidae

Carabidae

Stapylinidae

Curculionidae

Curculionidae

Curculionidae

Pselaphidae

Carabidae

Carabidae

Carabidae

Carabidae

Carabidae

Cantharidae

Cantharidae

Curculionidae

Rhynchaeninae

Scydmanidae

Scydmanidae

Stapylinidae

Stapylinidae

Stapylinidae

Stapylinidae

Stapylinidae

Stapylinidae

Stapylinidae

Carabidae

Stapylinidae

Stapylinidae

Tenebrionidae

Carabidae

Pselaphidae

Stapylinidae

Stapylinidae

Sminthuridae

Arrhopalitidae

Isotomidae

Poduridae

Hypogastruridae

Hypogastruridae

Hypogastruridae

Hypogastruridae

Isotomidae

Isotomidae

Onychiuridae

Bourletiellidae

Sminthuridae

Dicyrtomidae

Entomobryidae

Entomobryidae

Entomobryidae

Entomobryidae
Functional group

Macrofauna predators

Macrofauna predators

Macrofauna predators

Macrofauna predators

Macrofauna predators

Macrofauna predators

Macrofauna herbivores

Macrofauna herbivores

Macrofauna herbivores

Macrofauna predators

Macrofauna predators

Macrofauna predators

Macrofauna predators

Macrofauna predators

Macrofauna predators

Macrofauna predators

Macrofauna predators

Macrofauna herbivores

Macrofauna herbivores

Macrofauna predators

Macrofauna predators

Macrofauna predators

Macrofauna predators

Macrofauna predators

Macrofauna predators

Macrofauna predators

Macrofauna predators

Macrofauna predators

Macrofauna predators

Macrofauna predators

Macrofauna predators

Macrofauna decomposers

Macrofauna predators

Macrofauna predators

Macrofauna predators

Macrofauna predators

Mesofauna decomposers

Mesofauna decomposers

Mesofauna decomposers

Mesofauna decomposers

Mesofauna decomposers

Mesofauna decomposers

Mesofauna decomposers

Mesofauna decomposers

Mesofauna decomposers

Mesofauna decomposers

Mesofauna decomposers

Mesofauna decomposers

Mesofauna decomposers

Mesofauna decomposers

Mesofauna decomposers

Mesofauna decomposers

Mesofauna decomposers

Mesofauna decomposers 
Taxonomic group Species

Collembola

Collembola

Collembola

Collembola

Collembola

Collembola

Collembola

Collembola

Collembola

Collembola

Collembola

Collembola

Collembola

Collembola

Collembola

Collembola

Collembola

Collembola

Collembola

Collembola

Collembola

Collembola

Collembola

Collembola

Collembola

Collembola

Collembola

Collembola

Collembola

Collembola

Collembola

Collembola

Collembola

Collembola

Collembola

Collembola

Collembola

Collembola

Collembola

Collembola

Collembola

Collembola

Collembola

Collembola

Collembola

Collembola

Collembola

Collembola

Collembola

Collembola

Collembola

Collembola

Collembola

Collembola
Folsomia brevicauda

Folsomia fimetaria

Folsomia ksenemani

Folsomia litsteri

Folsomia quadrioculata

Folsomia spinosa

Friesea claviseta

Friesea mirabilis

Friesea truncata

Gisianus flammeolus

Hypogastrura burkilli

Hypogastrura purpurescens

Isotoma hiemalis

Isotomiella minor

Isotomurus palustris

Lepidocyrtus curvicolis

Lepidocyrtus cyaneus

Lepidocyrtus lanuginosus

Lepidocyrtus lignorum

Lipothrix (Sphyrotheca) lubbocki

Megalothorax minimus

Mesaphorura italica

Mesaphorura jarmiliae

Mesaphorura macrochaeta

Mesaphorura sylvatica

Mesaphorura tenuisensillata

Mesaphorura yosii

Metaphorura affinis

Micanurida forsslundi

Micranurida cf. sensillata

Micranurida granulata

Micranurida pygmaea

Micraphorura absoloni

Neanura muscorum

Neelides minutus

Neonaphorura dubosqi

Neotullbergia ramicuspis

Oncopodura crassicornis

Orchesella bifasciata

Orchesella cf flavescens

Paratullbergia callipygos

Paratullbergia macdougalli

Parisotoma notabilis

Proisotoma minima

Proisotoma minuta

Protaphorura armata

Protaphorura aurantiaca

Protaphorura fimata

Protaphorura quadriocellata

Pseudachorutes cf dubius

Pseudachorutes subcrassus

Pseudanurophorus binoculatus

Pseudosinella alba

Pseudosinella decipiens
Family

Functional group

Isotomidae

Isotomidae

Isotomidae

Isotomidae

Isotomidae

Isotomidae

Neanuridae

Neanuridae

Neanuridae

Katiannidae

Hypogastruridae

Hypogastruridae

Isotomidae

Isotomidae

Isotomidae

Entomobryidae

Entomobryidae

Entomobryidae

Entomobryidae

Sminthuridae

Neelidae

Tullbergiidae

Tullbergiidae

Tullbergiidae

Tullbergiidae

Tullbergiidae

Tullbergiidae

Tullbergiidae

Neanuridae

Neanuridae

Neanuridae

Neanuridae

Onychiuridae

Neanuridae

Neelidae

Tullbergiidae

Onychiuridae

Oncopoduridae

Entomobryidae

Entomobryidae

Tullbergiidae

Tullbergiidae

Isotomidae

Isotomidae

Isotomidae

Onychiuridae

Onychiuridae

Onychiuridae

Onychiuridae

Neanuridae

Neanuridae

Isotomidae

Entomobryidae

Entomobryidae
Mesofauna decomposers

Mesofauna decomposers

Mesofauna decomposers

Mesofauna decomposers

Mesofauna decomposers

Mesofauna decomposers

Mesofauna predators

Mesofauna predators

Mesofauna predators

Mesofauna decomposers

Mesofauna decomposers

Mesofauna decomposers

Mesofauna decomposers

Mesofauna decomposers

Mesofauna decomposers

Mesofauna decomposers

Mesofauna decomposers

Mesofauna decomposers

Mesofauna decomposers

Mesofauna decomposers

Mesofauna decomposers

Mesofauna decomposers

Mesofauna decomposers

Mesofauna decomposers

Mesofauna decomposers

Mesofauna decomposers

Mesofauna decomposers

Mesofauna decomposers

Mesofauna predators

Mesofauna predators

Mesofauna predators

Mesofauna predators

Mesofauna decomposers

Mesofauna predators

Mesofauna decomposers

Mesofauna decomposers

Mesofauna decomposers

Mesofauna decomposers

Mesofauna decomposers

Mesofauna decomposers

Mesofauna predators

Mesofauna predators

Mesofauna decomposers

Mesofauna decomposers

Mesofauna decomposers

Mesofauna decomposers

Mesofauna decomposers

Mesofauna decomposers

Mesofauna decomposers

Mesofauna predators

Mesofauna predators

Mesofauna decomposers

Mesofauna decomposers

Mesofauna decomposers 
Taxonomic

Collembola

Collembola

Collembola

Collembola

Collembola

Collembola

Collembola

Collembola

Collembola

Collembola

Collembola

Collembola

Collembola

Collembola

Collembola

Collembola

Diplopoda

Diplopoda

Diplopoda

Diplopoda

Diplopoda

Diplopoda

Diplopoda

Diplopoda

Diplopoda

Diplopoda

Diplopoda

Diplopoda

Diplopoda

Diplopoda

Diplopoda

Diplopoda

Diplopoda

Diplopoda

Diplopoda

Diplura

Gastropoda

Gastropoda

Gastropoda

Gastropoda

Gastropoda

Gastropoda

Gastropoda

Gastropoda

Gastropoda

Gastropoda

Gastropoda

Gastropoda

Gastropoda

Gastropoda

Gastropoda

Gastropoda

Gastropoda
Family

Pseudosinella immaculata

Pseudosinella ksenemani

Sminthurinus aureus

Sminthurinus niger

Sminthurus viridis

Sphaeridia pumilis

Stenaphorura denisi

Stenaphorura quadrispina

Supraphorura furcifera

Tomocerus baudoti

Tomocerus flavescens

Tomocerus minor

Tomocerus minutus

Tomocerus vulgaris

Willemia anophthalma

Willemia aspinata

Xenylla grisea

Allaiulus nitidus

Brachyiulus pusillus

Chordeuma silvestre

Geoglomeris cf subteraneus

Glomeris connexa

Glomeris conspersa

Glomeris hexasticha

Glomeris marginata

Glomeris undulata

Megaphyllum projectum

Melogona cf voigti

Polydesmus angustus

Polydesmus complanatus

Polydesmus denticulatus

Polydesmus inconstans

Polyxenus lagurus

Proteroiulus fuscus

Tachypodoiulus niger

Unciger foetidus

Campodea cf plusiochaeta

Aegopinella nitens

Aegopinella nitidula

Aegopinella pura

Arianta arbustorum

Arion ater

Arion fuscus

Arion intermedicus

Arion silvaticus

Azeca goodalli

Cepea hortensis

Cepea nemoralis

Clausilia bidentata

Cochlicopa lubrica

Cochlodina laminata

Discus rotundatus

Ena montana

Euconulus fulvus
Entomobryidae

Entomobryidae

Katiannidae

Katiannidae

Sminthuridae

Sminthurididae

Tullbergiidae

Tullbergiidae

Onychiuridae

Tomoceridae

Tomoceridae

Tomoceridae

Tomoceridae

Tomoceridae

Hypogastruridae

Hypogastruridae

Hypogastruridae

Julidae

Julidae

Chordeumatidae

Glomeridae

Glomeridae

Glomeridae

Glomeridae

Glomeridae

Glomeridae

Julidae

Chordeumatidae

Polydesmidae

Polydesmidae

Polydesmidae

Polydesmidae

Polyxenidae

Blaniulidae

Julidae

Julidae

Campodeidae

Oxychilidae

Oxychilidae

Oxychilidae

Helicidae

Arionidae

Arionidae

Arionidae

Arionidae

Azecidae

Helicidae

Helicidae

Clausiliidae

Cochlicopidae

Clausiliidae

Patulidae

Enidae

Euconulidae
Functional group

Mesofauna decomposers

Mesofauna decomposers

Mesofauna decomposers

Mesofauna decomposers

Mesofauna decomposers

Mesofauna decomposers

Mesofauna decomposers

Mesofauna decomposers

Mesofauna decomposers

Mesofauna decomposers

Mesofauna decomposers

Mesofauna decomposers

Mesofauna decomposers

Mesofauna decomposers

Mesofauna decomposers

Mesofauna decomposers

Mesofauna decomposers

Macrofauna decomposers

Macrofauna decomposers

Macrofauna decomposers

Macrofauna decomposers

Macrofauna decomposers

Macrofauna decomposers

Macrofauna decomposers

Macrofauna decomposers

Macrofauna decomposers

Macrofauna decomposers

Macrofauna decomposers

Macrofauna decomposers

Macrofauna decomposers

Macrofauna decomposers

Macrofauna decomposers

Macrofauna decomposers

Macrofauna decomposers

Macrofauna decomposers

Macrofauna decomposers

Macrofauna predators

Macrofauna decomposers

Macrofauna decomposers

Macrofauna decomposers

Macrofauna herbivores

Macrofauna decomposers

Macrofauna decomposers

Macrofauna decomposers

Macrofauna decomposers

Macrofauna decomposers

Macrofauna herbivores

Macrofauna herbivores

Macrofauna decomposers

Macrofauna decomposers

Macrofauna decomposers

Macrofauna decomposers

Macrofauna decomposers

Macrofauna decomposers 
Taxonomic group Species

Family

Gastropoda
Gastropoda
Gastropoda
Gastropoda
Gastropoda
Gastropoda
Gastropoda
Gastropoda
Gastropoda
Isopoda
Isopoda
Isopoda

Isopoda

Isopoda

Isopoda

Isopoda

Isopoda

Isopoda

Isopoda

Isopoda

Isopoda

Isopoda

Lumbricidae

Lumbricidae

Lumbricidae

Lumbricidae

Lumbricidae

Lumbricidae

Lumbricidae

Lumbricidae

Lumbricidae

Lumbricidae

Mesostigmata

Mesostigmata

Mesostigmata

Mesostigmata

Mesostigmata

Mesostigmata

Mesostigmata

Mesostigmata

Mesostigmata

Mesostigmata

Mesostigmata

Mesostigmata

Mesostigmata

Mesostigmata

Mesostigmata

Mesostigmata

Mesostigmata

Mesostigmata

Mesostigmata

Mesostigmata

Mesostigmata

Mesostigmata
Helicigona lapicida

Helicodonta obvoluta

Lehmannia marginata

Limax cinereoniger

Macrogastra ventricosa

Monachoides incarnatus

Nesovitrea hammonis

Trichia striolata

Vitrea diaphana

Armadillidium opacum

Haplophthalmus mengei

Ligidium hypnorum

Oniscus asellus

Philoscia muscorum

Porcellio conspersum

Porcellio dilatatus

Porcellio montanus

Porcellio spinicornis

Trachelipus rathkei

Trachelipus ratzeburgii

Trichoniscus pusillus

Trichoniscus pygmaeus

Aporectodea longa

Aporrectodea caliginosa

Aporrectodea rosea

Dendrobaena octaedra

Dendrobaena pygmaea

Dendrodrilus rubidus

Lumbricus castaneus

Lumbricus rubellus

Lumbricus terrestris

Octolasion tyrtaeum

Amblyseius of nemorivagus

Amblyseius similifloridanus

Arctoseius magnanalis

Asca bicornis

Cornodendrolaelaps cf cornutulus

Dinychus perforatus

Epicrius canestrinii

Epicrius cf spinituberculatus

Epicrius schusteri

Geholaspis aeneus

Geholaspis longispinosus

Geholaspis mandibularis

Holoparasitus stramenti

Hypoaspis aculeifer

Lasioseius lawrencei

Leioseius bicolor

Leioseius elongatus

Leitneria granulata

Leptogamasus cf tectegynellus

Leptogamasus suecicus

Lysigamasus celticus

Lysigamasus of arcuatus
Helicidae

Helicodontidae

Limacidae

Limacidae

Clausiliidae

Hygromiidae

Oxychilidae

Helicidae

Pristilomatidae

Armadillidae

Trichoniscidae

Ligiidae

Oniscidae

Philosciidae

Porcellionidae

Porcellionidae

Porcellionidae

Porcellionidae

Trachelipidae

Trachelipidae

Trichoniscidae

Trichoniscidae

Lumbricidae

Lumbricidae

Lumbricidae

Lumbricidae

Lumbricidae

Lumbricidae

Lumbricidae

Lumbricidae

Lumbricidae

Lumbricidae

Phytoseinae

Phytoseinae

Ascidae

Ascidae

Rhodacaridae

Urodinychidae

Epicriidae

Epicriidae

Epicriidae

Macrochelidae

Macrochelidae

Macrochelidae

Pergamasinae

Hypoaspididae

Podocinidae

Ascidae

Ascidae

Halolaelapidae

Pergamasinae

Pergamasinae

Pergamasinae

Pergamasinae
Functional group

Macrofauna decomposers

Macrofauna herbivores

Macrofauna decomposers

Macrofauna decomposers

Macrofauna decomposers

Macrofauna decomposers

Macrofauna decomposers

Macrofauna decomposers

Macrofauna decomposers

Macrofauna decomposers

Macrofauna decomposers

Macrofauna decomposers

Macrofauna decomposers

Macrofauna decomposers

Macrofauna decomposers

Macrofauna decomposers

Macrofauna decomposers

Macrofauna decomposers

Macrofauna decomposers

Macrofauna decomposers

Macrofauna decomposers

Macrofauna decomposers

Macrofauna decomposers

Macrofauna decomposers

Macrofauna decomposers

Macrofauna decomposers

Macrofauna decomposers

Macrofauna decomposers

Macrofauna decomposers

Macrofauna decomposers

Macrofauna decomposers

Macrofauna decomposers

Mesofauna predators

Mesofauna predators

Mesofauna predators

Mesofauna predators

Mesofauna predators

Mesofauna predators

Mesofauna predators

Mesofauna predators

Mesofauna predators

Mesofauna predators

Mesofauna predators

Mesofauna predators

Mesofauna predators

Mesofauna predators

Mesofauna predators

Mesofauna predators

Mesofauna predators

Mesofauna predators

Mesofauna predators

Mesofauna predators

Mesofauna predators

Mesofauna predators 
Taxonomic group Species

Family

Mesostigmata

Mesostigmata

Mesostigmata

Mesostigmata

Mesostigmata

Mesostigmata

Mesostigmata

Mesostigmata

Mesostigmata

Mesostigmata

Mesostigmata

Mesostigmata

Mesostigmata

Mesostigmata

Mesostigmata

Mesostigmata

Mesostigmata

Mesostigmata

Mesostigmata

Mesostigmata

Mesostigmata

Mesostigmata

Mesostigmata

Mesostigmata

Mesostigmata

Mesostigmata

Mesostigmata

Mesostigmata

Mesostigmata

Mesostigmata

Mesostigmata

Mesostigmata

Mesostigmata

Mesostigmata

Mesostigmata

Mesostigmata

Mesostigmata

Mesostigmata

Mesostigmata

Mesostigmata

Mesostigmata

Mesostigmata

Mesostigmata

Mesostigmata

Mesostigmata

Mesostigmata

Mesostigmata

Mesostigmata

Mesostigmata

Mesostigmata

Mesostigmata

Mesostigmata

Mesostigmata

Mesostigmata
Lysigamasus cf conus

Lysigamasus cf rostriforceps

Lysigamasus cf runcatellus

Lysigamasus of wasmanni

Lysigamasus cornutus

Lysigamasus digitulus

Lysigamasus jugincola

Lysigamasus lapponicus

Lysigamasus minorleitneriae

Lysigamasus misellus

Lysigamasus parunciger

Lysigamasus puerilis

Lysigamasus runcatellus

Lysigamasus solitarius

Lysigamasus truncellus

Lysigamasus vagabundus

Macrocheles cf opacus aciculatus

Macrocheles dentatus

Macrocheles montanus

Macrocheles opacus

Pachylaelaps bellicosus

Pachylaelaps cf vexillifer

Pachylaelaps fuscinuliger

Pachylaelaps laeuchlii

Pachylaelaps longisetosus

Pachylaelaps regularis

Pachylaelaps tesselatus

Pachyseius angustus

Pachyseius humeralis

Pergamasus crassipes

Pergamasus norvegicus

Pergamasus quisquiliarum

Pergamasus septentrionalis

Prozercon cf traeghardi

Prozercon fimbriatus

Prozercon kochi

Pseudoparasitus placentulus

Rhodacarellus kreuzi

Rhodacarus agrestis

Rhodacarus coronatus

Trachytes aegrota

Trachytes pauperior

Trichouropoda cf obscura

Trichouropoda ovalis

Urodiaspis shcherbakae

Urodiaspis tecta

Uropoda athiasae

Uropoda cassidea

Uropoda cf splendida

Uropoda minima

Uroseius cylindricus

Veigaia agilis

Veigaia cerva

Veigaia cf mollis
Pergamasinae

Pergamasinae

Pergamasinae

Pergamasinae

Pergamasinae

Pergamasinae

Pergamasinae

Pergamasinae

Pergamasinae

Pergamasinae

Pergamasinae

Pergamasinae

Pergamasinae

Pergamasinae

Pergamasinae

Pergamasinae

Macrochelidae

Macrochelidae

Macrochelidae

Macrochelidae

Pachylaelapidae

Pachylaelapidae

Pachylaelapidae

Pachylaelapidae

Pachylaelapidae

Pachylaelapidae

Pachylaelapidae

Macrochelidae

Macrochelidae

Pergamasinae

Pergamasinae

Pergamasinae

Pergamasinae

Zerconidae

Zerconidae

Zerconidae

Hypoaspididae

Rhodacaridae

Rhodacaridae

Rhodacaridae

Trachytidae

Trachytidae

Trematuridae

Trematuridae

Urodinychidae

Urodinychidae

Uropodidae

Uropodidae

Uropodidae

Uropodidae

Polyaspidae

Veigaiaidae

Veigaiaidae

Veigaiaidae
Functional group

Mesofauna predators

Mesofauna predators

Mesofauna predators

Mesofauna predators

Mesofauna predators

Mesofauna predators

Mesofauna predators

Mesofauna predators

Mesofauna predators

Mesofauna predators

Mesofauna predators

Mesofauna predators

Mesofauna predators

Mesofauna predators

Mesofauna predators

Mesofauna predators

Mesofauna predators

Mesofauna predators

Mesofauna predators

Mesofauna predators

Mesofauna predators

Mesofauna predators

Mesofauna predators

Mesofauna predators

Mesofauna predators

Mesofauna predators

Mesofauna predators

Mesofauna predators

Mesofauna predators

Mesofauna predators

Mesofauna predators

Mesofauna predators

Mesofauna predators

Mesofauna predators

Mesofauna predators

Mesofauna predators

Mesofauna predators

Mesofauna predators

Mesofauna predators

Mesofauna predators

Mesofauna predators

Mesofauna predators

Mesofauna predators

Mesofauna predators

Mesofauna predators

Mesofauna predators

Mesofauna predators

Mesofauna predators

Mesofauna predators

Mesofauna predators

Mesofauna predators

Mesofauna predators

Mesofauna predators

Mesofauna predators 
Taxonomic group Species

Family

Mesostigmata

Mesostigmata

Mesostigmata

Mesostigmata

Mesostigmata

Mesostigmata

Mesostigmata

Mesostigmata

Mesostigmata

Mesostigmata

Mesostigmata

Mesostigmata

Opiliones

Opiliones

Opiliones

Oribatida

Oribatida

Oribatida

Oribatida

Oribatida

Oribatida

Oribatida

Oribatida

Oribatida

Oribatida

Oribatida

Oribatida

Oribatida

Oribatida

Oribatida

Oribatida

Oribatida

Oribatida

Oribatida

Oribatida

Oribatida

Oribatida

Oribatida

Oribatida

Oribatida

Oribatida

Oribatida

Oribatida

Oribatida

Oribatida

Oribatida

Oribatida

Oribatida

Oribatida

Oribatida

Oribatida

Oribatida

Oribatida

Oribatida
Veigaia cf propingua

Veigaia exigua

Veigaia kochi

Veigaia nemorensis

Veigaia planicola

Vulgarogamasus kraepelini

Vulgarogamasus remberti

Zercon cf peltatus

Zercon of romagniolus

Zercon of triangularis

Zercon gurensis

Zerconopsis remiger

Anelasmocephalus cambridgei

Trogulus nepaeformis

Trogulus tricarinatus

Achipteria coleoptrata

Achipteria nitens

Adoristes ovatus

Allosuctobelba grandis

Amerus polonicus

Atropacarus striculus

Belba corynopus

Berniniella bicarinata

Berniniella conjuncta

Berniniella dungeri

Berniniella sigma

Carabodes coriaceus

Carabodes femoralis

Carabodes labyrinthicus

Carabodes ornatus

Carabodes subarcticus

Cepheus cepheiformes

Ceratozetes gracilis

Chamobates borealis

Chamobates cuspidatus

Chamobates pusillus

Chamobates subglobulus

Chamobates voigtsi

Cultroribula bicultrata

Cymberemaeus cymba

Damaeobelba minutissima

Damaeus auritus

Damaeus onustus

Damaeus riparius

Dissorhina ornata

Edwarzetes edwardsii

Eniochthonius minutissimus

Epidamaeus setiger

Eulohmannia ribagai

Eupelops hirtus

Eupelops plicatus

Eupelops torulosus

Euzetes globulus

Fosseremus laciniatus
Veigaiaidae

Veigaiaidae

Veigaiaidae

Veigaiaidae

Veigaiaidae

Parasitidae

Parasitidae

Zerconidae

Zerconidae

Zerconidae

Zerconidae

Ascidae

Trogulidae

Trogulidae

Trogulidae

Achipteriidae

Achipteriidae

Liacaridae

Suctobelbidae

Ameridae

Phthiracaridae

Damaeidae

Oppiidae

Oppiidae

Oppiidae

Oppiidae

Carabodidae

Carabodidae

Carabodidae

Carabodidae

Carabodidae

Cepheidae

Ceratozetidae

Chamobatidae

Chamobatidae

Chamobatidae

Chamobatidae

Chamobatidae

Astegistidae

Cymberemaeidae

Damaeidae

Damaeidae

Damaeidae

Damaeidae

Oppiidae

Ceratozetidae

Eniochthoniidae

Damaeidae

Eulohmanniidae

Phenopelopidae

Phenopelopidae

Phenopelopidae

Euzetidae

Damaeolidae
Functional group

Mesofauna predators

Mesofauna predators

Mesofauna predators

Mesofauna predators

Mesofauna predators

Mesofauna predators

Mesofauna predators

Mesofauna predators

Mesofauna predators

Mesofauna predators

Mesofauna predators

Mesofauna predators

Macrofauna predators

Macrofauna predators

Macrofauna predators

Mesofauna decomposers

Mesofauna decomposers

Mesofauna decomposers

Mesofauna predators

Mesofauna decomposers

Mesofauna decomposers

Mesofauna decomposers

Mesofauna predators

Mesofauna predators

Mesofauna predators

Mesofauna predators

Mesofauna decomposers

Mesofauna decomposers

Mesofauna decomposers

Mesofauna decomposers

Mesofauna decomposers

Mesofauna decomposers

Mesofauna decomposers

Mesofauna decomposers

Mesofauna decomposers

Mesofauna decomposers

Mesofauna decomposers

Mesofauna decomposers

Mesofauna decomposers

Mesofauna decomposers

Mesofauna decomposers

Mesofauna decomposers

Mesofauna decomposers

Mesofauna decomposers

Mesofauna predators

Mesofauna decomposers

Mesofauna decomposers

Mesofauna decomposers

Mesofauna decomposers

Mesofauna decomposers

Mesofauna decomposers

Mesofauna decomposers

Mesofauna decomposers

Mesofauna decomposers 
Taxonomic group Species

Oribatida

Oribatida

Oribatida

Oribatida

Oribatida

Oribatida

Oribatida

Oribatida

Oribatida

Oribatida

Oribatida

Oribatida

Oribatida

Oribatida

Oribatida

Oribatida

Oribatida

Oribatida

Oribatida

Oribatida

Oribatida

Oribatida

Oribatida

Oribatida

Oribatida

Oribatida

Oribatida

Oribatida

Oribatida

Oribatida

Oribatida

Oribatida

Oribatida

Oribatida

Oribatida

Oribatida

Oribatida

Oribatida

Oribatida

Oribatida

Oribatida

Oribatida

Oribatida

Oribatida

Oribatida

Oribatida

Oribatida

Oribatida

Oribatida

Oribatida

Oribatida

Oribatida

Oribatida

Oribatida
Fuscozetes setosus

Galumna lanceata

Galumna tarsipennata

Hermannia gibba

Hungarobelba pyrenaica

Hypochthonius luteus

Hypochthonius rufulus

Jugatala angulata

Liacarus coracinus

Liacarus subterraneus

Liacarus xylariae

Liebstadia humerata

Liebstadia similis

Metabelba pulverosa

Micreremus brevipes

Micreremus gracilior

Microppia minus

Microtritia minima

Nanhermannia elegantula

Nanhermannia nana

Neotrichoppia confinis

Nothrus palustris

Nothrus silvestris

Ophidiotrichus tectus

Oppiella acuminata

Oppiella falcata

Oppiella fallax

Oppiella marginedentata

Oppiella nova

Oppiella obsoleta

Oppiella propinqua

Oppiella subpectinata

Oribatella calcarata

Oribatula tibialis

Pantelozetes paolii

Parachipteria punctata

Pergalumna nervosa

Phthiracarus affinis

Phthiracarus anonymus

Phthiracarus borosetosus

Phthiracarus cf crenophilus

Phthiracarus clavatus

Phthiracarus compressus

Phthiracarus crinitus

Phthiracarus ferrugineus

Phthiracarus globosus

Phthiracarus italicus

Phthiracarus laevigatus

Phthiracarus lentulus

Phthiracarus longulus

Phthiracarus stramineus

Pilogalumna crassiclava

Pilogalumna tenuiclava

Platynothrus peltifer
Family

Functional group

Ceratozetidae

Galumnidae

Galumnidae

Hermanniidae

Belbodamaeidae

Hypochthoniidae

Hypochthoniidae

Ceratozetidae

Liacaridae

Liacaridae

Liacaridae

Scheloribatidae

Scheloribatidae

Damaeidae

Micreremidae

Micreremidae

Oppiidae

Euphthiracaroidae

Nanhermanniidae

Nanhermanniidae

Oppiidae

Nothridae

Nothridae

Oribatellidae

Oppiidae

Oppiidae

Oppiidae

Oppiidae

Oppiidae

Oppiidae

Oppiidae

Oppiidae

Oribatellidae

Oribatulidae

Thyrisomidae

Achipteriidae

Galumnidae

Phthiracaridae

Phthiracaridae

Phthiracaridae

Phthiracaridae

Phthiracaridae

Phthiracaridae

Phthiracaridae

Phthiracaridae

Phthiracaridae

Phthiracaridae

Phthiracaridae

Phthiracaridae

Phthiracaridae

Phthiracaridae

Galumnidae

Galumnidae

Camisiidae
Mesofauna decomposers

Mesofauna decomposers

Mesofauna decomposers

Mesofauna decomposers

Mesofauna decomposers

Mesofauna predators

Mesofauna predators

Mesofauna decomposers

Mesofauna decomposers

Mesofauna decomposers

Mesofauna decomposers

Mesofauna decomposers

Mesofauna decomposers

Mesofauna decomposers

Mesofauna decomposers

Mesofauna decomposers

Mesofauna predators

Mesofauna decomposers

Mesofauna decomposers

Mesofauna decomposers

Mesofauna predators

Mesofauna decomposers

Mesofauna decomposers

Mesofauna decomposers

Mesofauna predators

Mesofauna predators

Mesofauna predators

Mesofauna predators

Mesofauna predators

Mesofauna predators

Mesofauna predators

Mesofauna predators

Mesofauna decomposers

Mesofauna decomposers

Mesofauna decomposers

Mesofauna decomposers

Mesofauna decomposers

Mesofauna decomposers

Mesofauna decomposers

Mesofauna decomposers

Mesofauna decomposers

Mesofauna decomposers

Mesofauna decomposers

Mesofauna decomposers

Mesofauna decomposers

Mesofauna decomposers

Mesofauna decomposers

Mesofauna decomposers

Mesofauna decomposers

Mesofauna decomposers

Mesofauna decomposers

Mesofauna decomposers

Mesofauna decomposers

Mesofauna decomposers 
Taxonomic group Species

Family

Functional group

Oribatida

Oribatida

Oribatida

Oribatida

Oribatida

Oribatida

Oribatida

Oribatida

Oribatida

Oribatida

Oribatida

Oribatida

Oribatida

Oribatida

Oribatida

Oribatida

Oribatida

Oribatida

Oribatida

Oribatida

Prostigmata

Pseudoscorpiones

Symphyla

Symphyla
Porobelba spinosa

Quadroppia hammerae

Quadroppia monstruosa

Quadroppia quadricarinata

Rhysotritia duplicata

Scheloribates initialis

Scheloribates laevigatus

Sphaerozetes piriformes

Steganacarus herculeanus

Steganacarus magnus

Suctobelba altvateri

Suctobelba trigona

Suctobelbella $s p$

Tectocepheus minor

Tectocepheus velatus alatus

Tectocepheus velatus sarekensis

Tectocepheus velatus velatus

Trichoribates novus

Tritegeus bisulcatus

Xenillus tegeocranus

Trombidium cf holosericeum

Neobisium carcinoides

Scolopendrella cf. subnuda

Scutigerella immaculata
Damaeidae

Quadroppiidae

Quadroppiidae

Quadroppiidae

Euphthiracaroidae

Scheloribatidae

Scheloribatidae

Ceratozetidae

Phthiracaridae

Phthiracaridae

Suctobelbidae

Suctobelbidae

Suctobelbidae

Tectocepheidae

Tectocepheidae

Tectocepheidae

Tectocepheidae

Ceratozetidae

Cepheidae

Liacaridae

Trombidiidae

Neobisidae

Scolopendrellidae

Scutigerellidae
Mesofauna decomposers

Mesofauna decomposers

Mesofauna decomposers

Mesofauna decomposers

Mesofauna decomposers

Mesofauna decomposers

Mesofauna decomposers

Mesofauna decomposers

Mesofauna decomposers

Mesofauna decomposers

Mesofauna predators

Mesofauna predators

Mesofauna predators

Mesofauna decomposers

Mesofauna decomposers

Mesofauna decomposers

Mesofauna decomposers

Mesofauna decomposers

Mesofauna decomposers

Mesofauna decomposers

Macrofauna predators

Macrofauna predators

Macrofauna decomposers

Macrofauna decomposers 


\section{Supplementary material}

\section{Chapter 3}

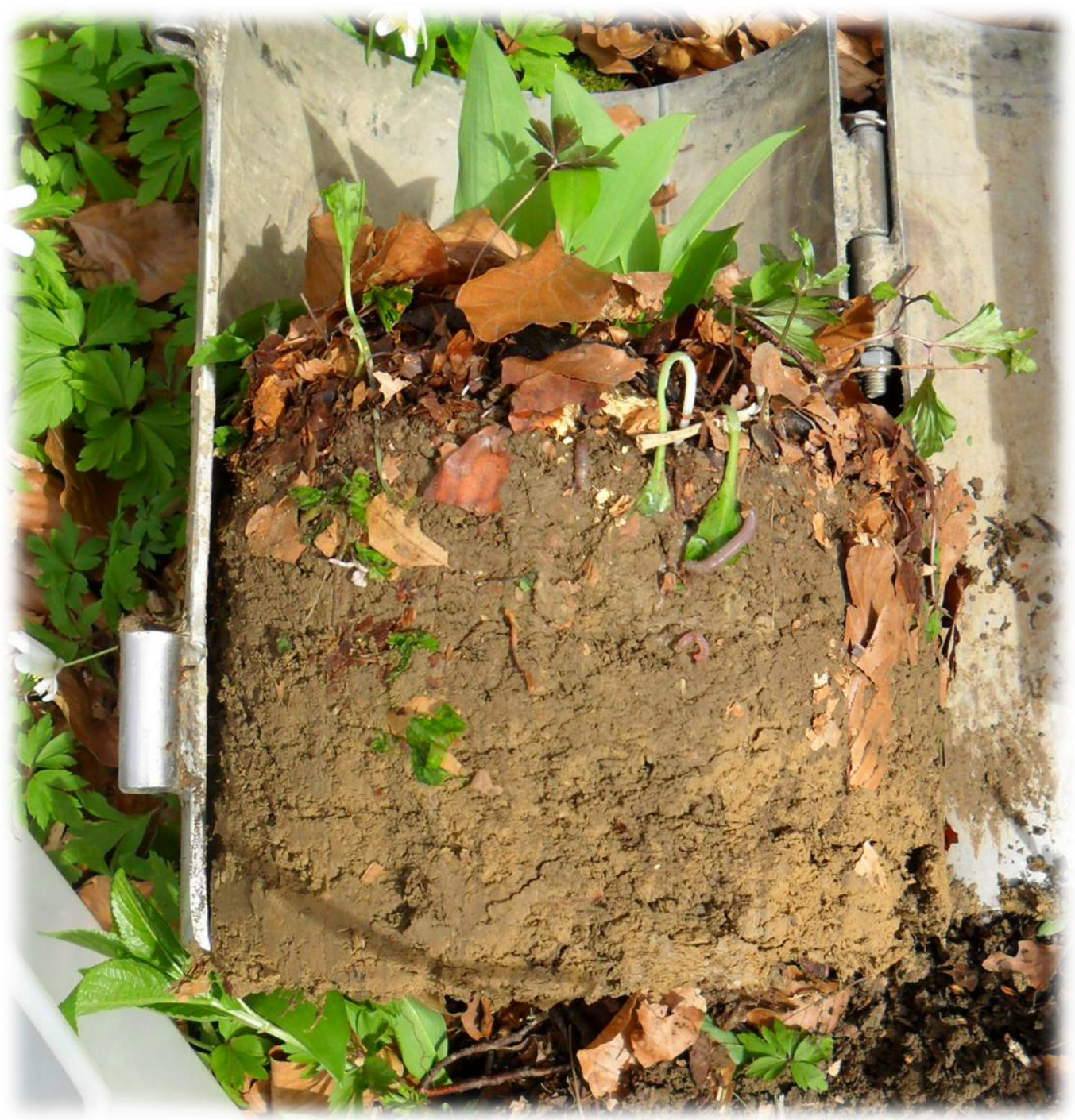




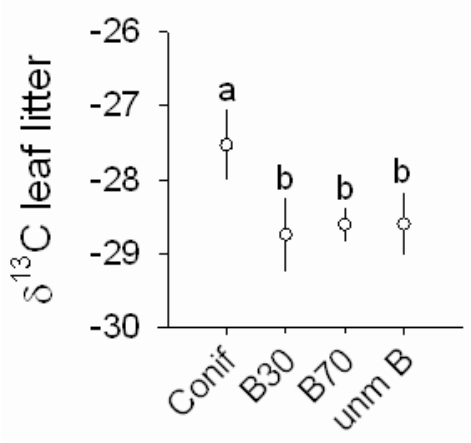

Fig. A1. $\delta^{13} \mathrm{C}$ signatures (means $\pm \mathrm{SD}$ ) of leaf litter of the four forest types studied (Conif $=$ coniferous forest, $\mathrm{B} 30$ = young managed beech, B70 = old managed beech, unm B = unmanaged beech); different letters indicate significant differences between means $(p<0.05$, Tukey's HSD).

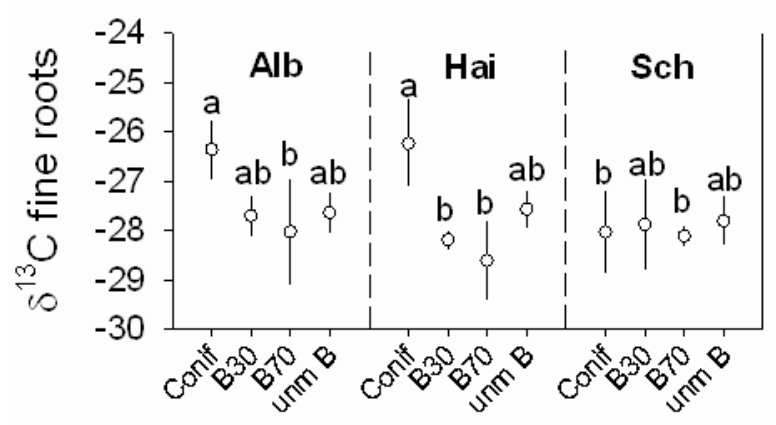

Fig. A2. $\delta^{13} \mathrm{C}$ signatures (means $\pm \mathrm{SD}$ ) of fine roots of trees of the four forest types in the three regions studied $($ Alb $=$ Swabian Alb, Hai $=$ Hainich, Sch $=$ Schorfheide, Conif $=$ coniferous forest, $\mathrm{B} 30$ = young managed beech, $\mathrm{B} 70$ = old managed beech, unm $\mathrm{B}=$ unmanaged beech); different letters indicate significant differences between means ( $p<0.05$, Tukey's HSD).
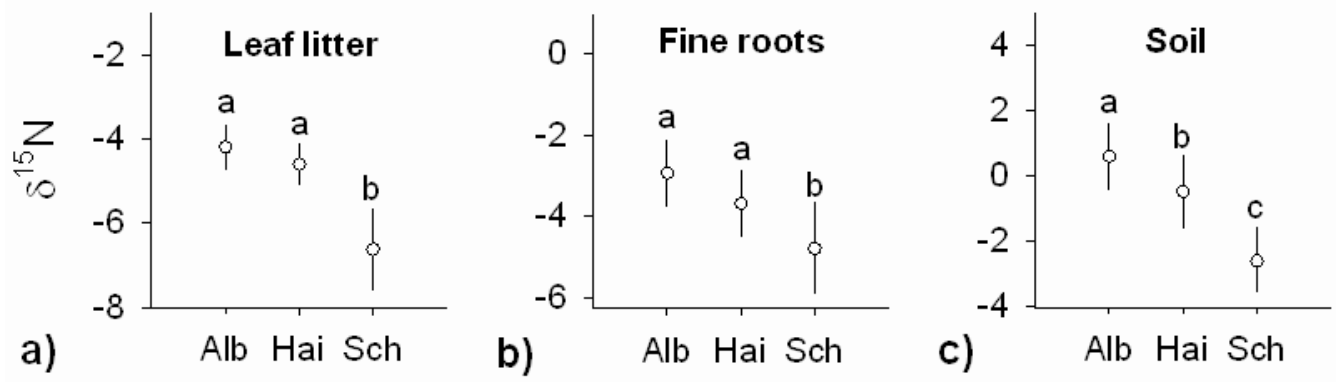

Fig. A3. $\delta^{15} \mathrm{~N}$ signatures (means $\pm \mathrm{SD}$ ) of (a) leaf litter, (b) fine roots and (c) soil of the three regions studied; for legend see Fig. A2; different letters indicate significant differences between means $(p<$ 0.05 , Tukey's HSD). 


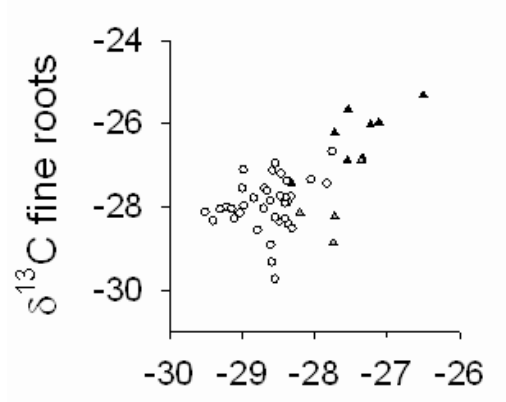

a) $\quad \delta^{13} \mathrm{C}$ leaf litter

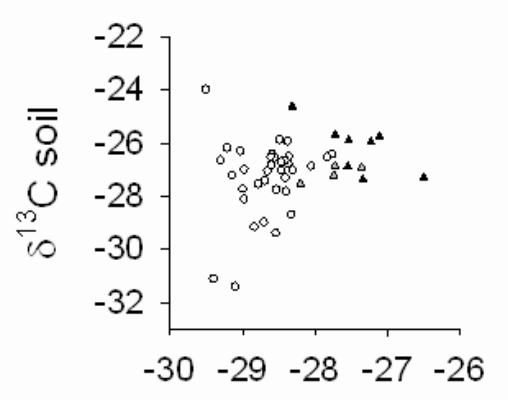

b) $\quad \delta^{13} \mathrm{C}$ leaf litter

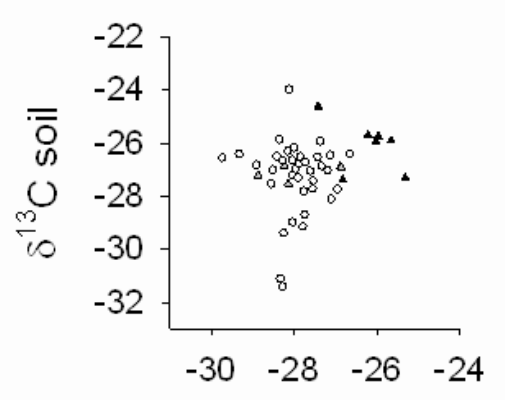

c) $\quad \delta^{13} \mathrm{C}$ fine roots

Fig. A4. Relationship between $\delta^{13} \mathrm{C}$ signatures of (a) leaf litter and fine roots $(r=0.63, p<0.001)$, (b) leaf litter and soil $(r=0.24, p=0.09)$, and (c) fine roots and soil $(r=0.20, p=0.18)$ in the studied forests (Pearson correlation); open dots $=$ beech, black triangles $=$ spruce, grey triangles $=$ pine.

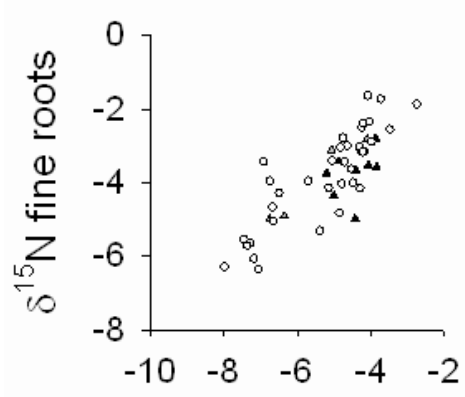

a)

$$
\delta^{15} \mathrm{~N} \text { leaf litter }
$$

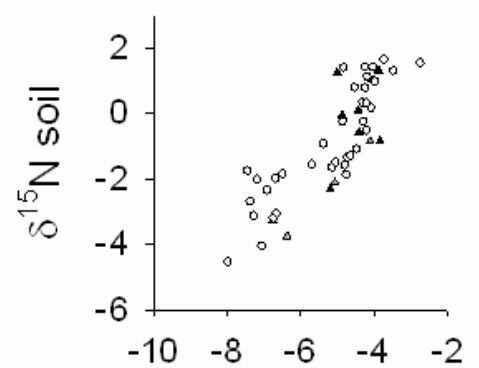

b) $\quad \delta^{15} \mathrm{~N}$ leaf litter

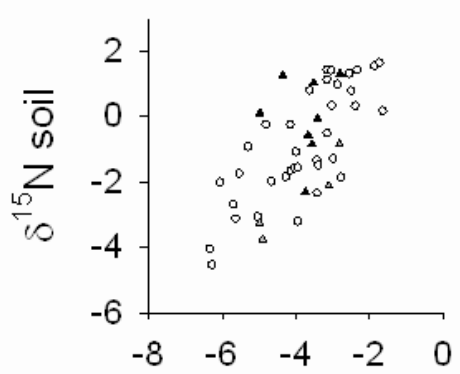

c) $\quad \delta^{15} \mathrm{~N}$ fine roots

Fig. A5. Relationship between $\delta^{15} \mathrm{~N}$ signatures of (a) leaf litter and fine roots $(r=0.82, p<0.001)$, (b) leaf litter and soil $(r=0.84, p<0.001)$, and (c) fine roots and soil $(r=0.70, p<0.001)$ in the studied forests $($ Pearson correlation); open dots $=$ beech, black triangles $=$ spruce, grey triangles $=$ pine. 


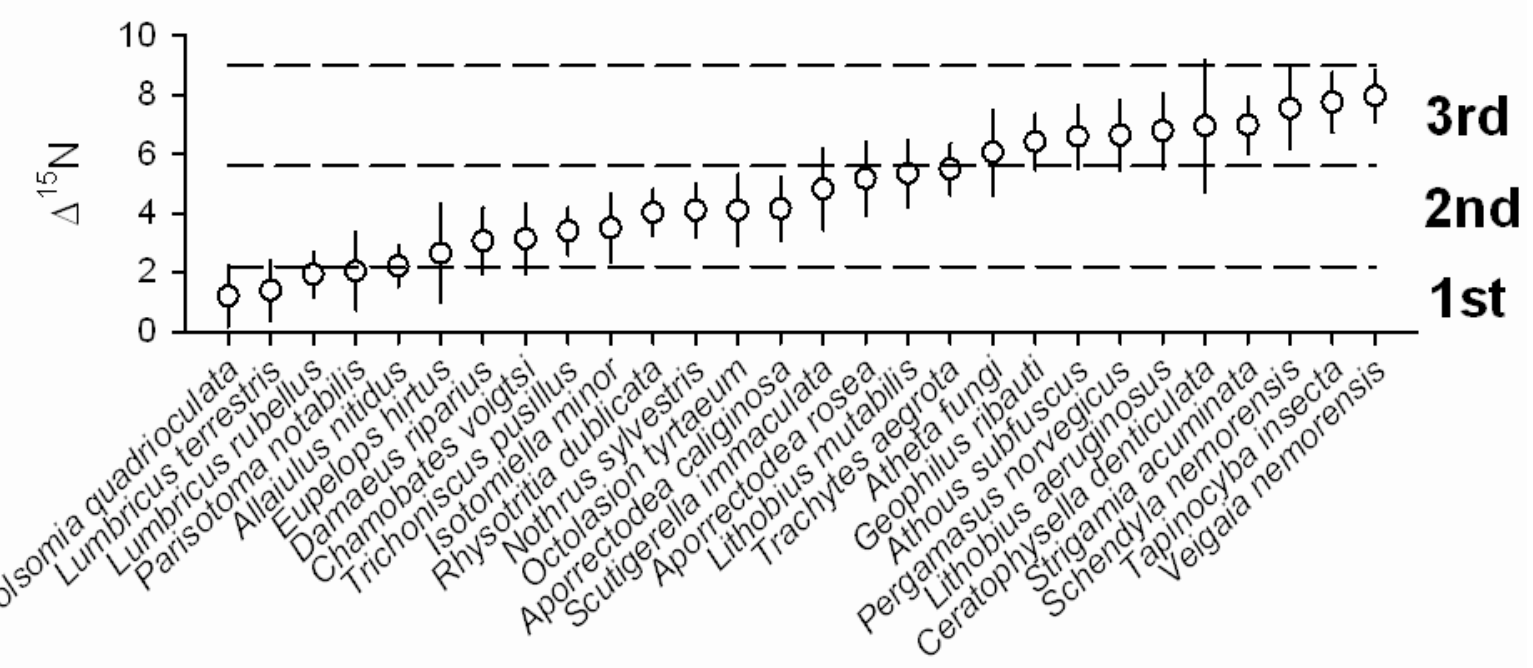

Fig. A6. Differences between $\delta^{15} \mathrm{~N}$ values of leaf litter and those of soil animal species $\left(\Delta^{15} \mathrm{~N}\right.$; means \pm SD); dashed lines denote boundaries for the first, second and third consumer level assuming a mean enrichment of $0.5 \%$ for the first and $3.4 \%$ for the second and third consumer level; each consumer level is assumed to span $3.4 \%$. 

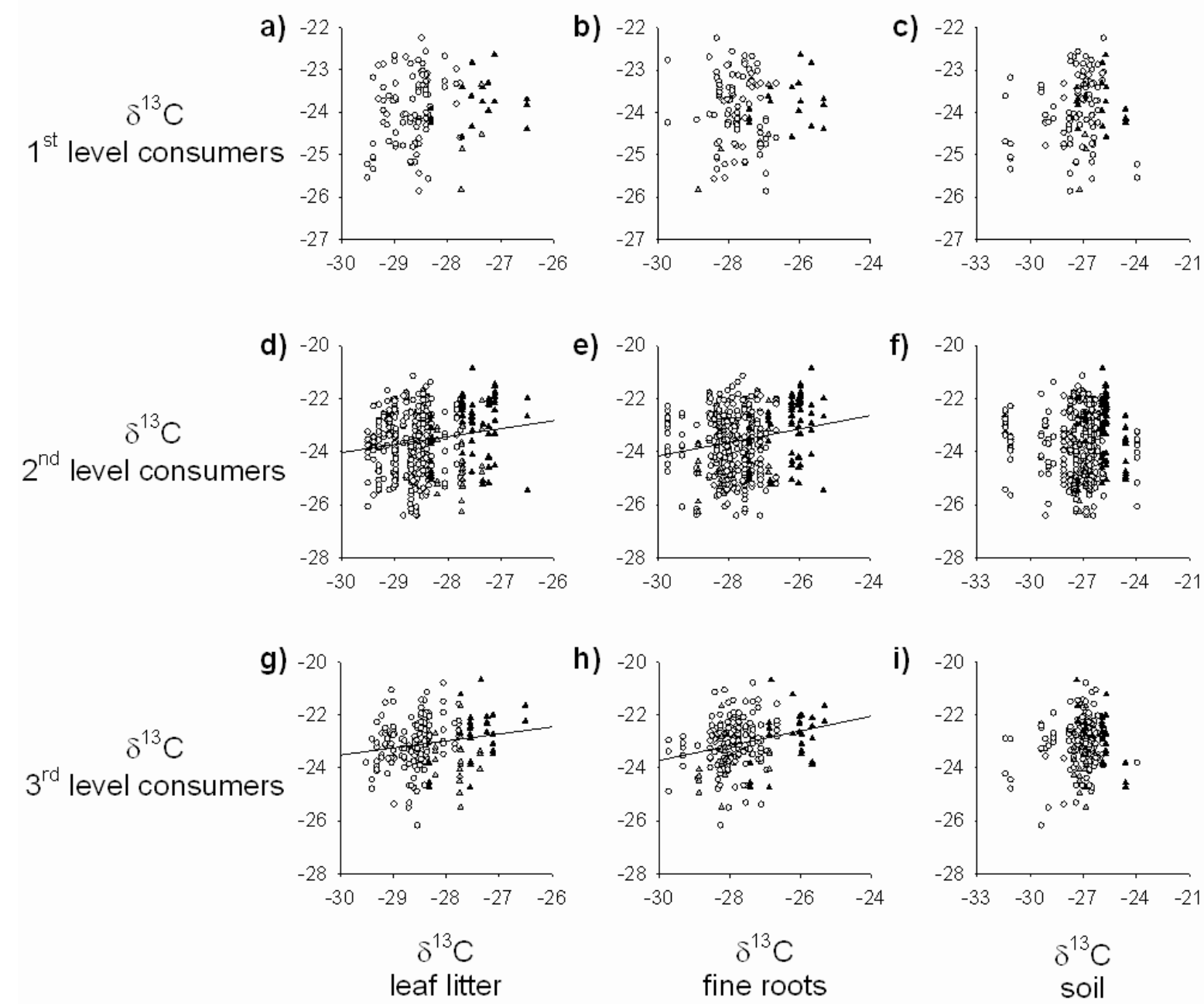

Fig. A7. Relationship between $\delta^{13} \mathrm{C}$ signatures of resources (leaf litter, fine roots and soil) and soil animals of different trophic levels (first, second and third level consumers); for $r^{2}$-and $p$-values see Table 1; open dots $=$ beech, black triangles $=$ spruce, grey triangles $=$ pine . 


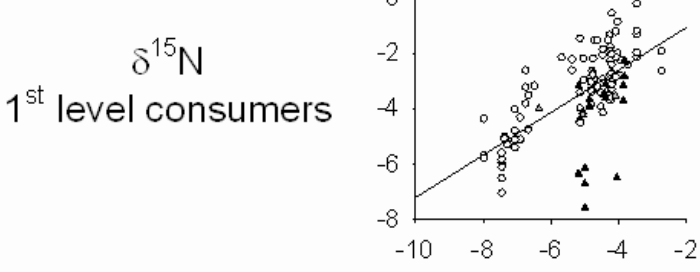

b)

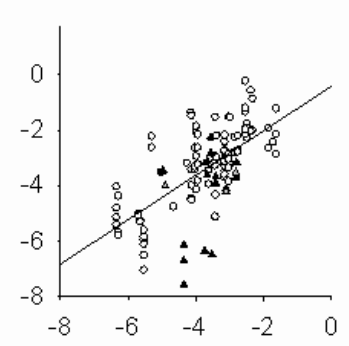

d)

$\delta^{15} \mathrm{~N}$

$2^{\text {nd }}$ level consumers

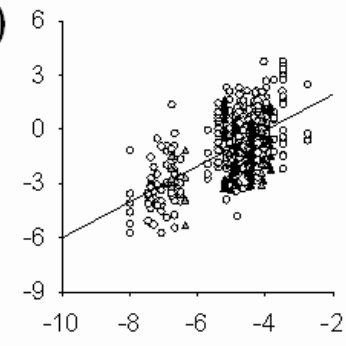

$\delta^{15} \mathrm{~N}$

$3^{\text {rd }}$ level consumers

g)

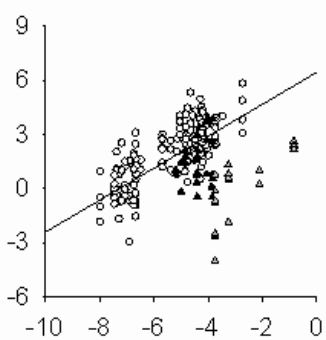

$\delta^{15} \mathrm{~N}$

leaf litter e)

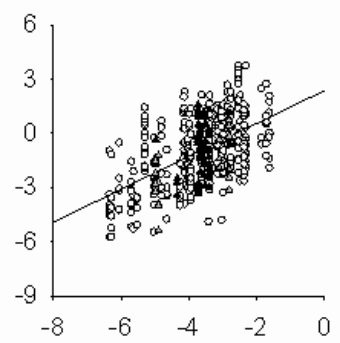

h)

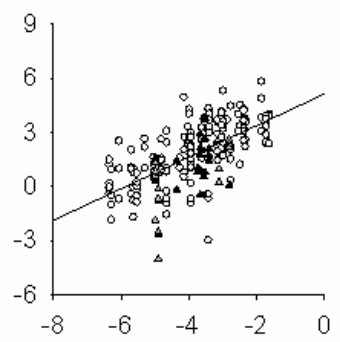

$\delta^{15} \mathrm{~N}$

fine roots c)

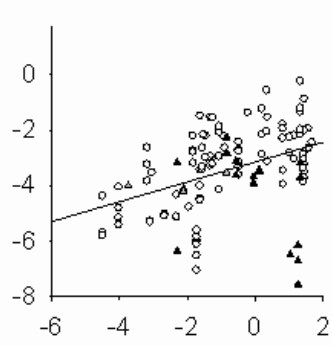

f)

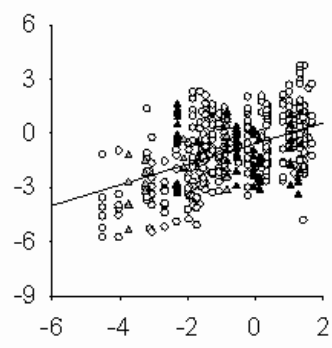

i)

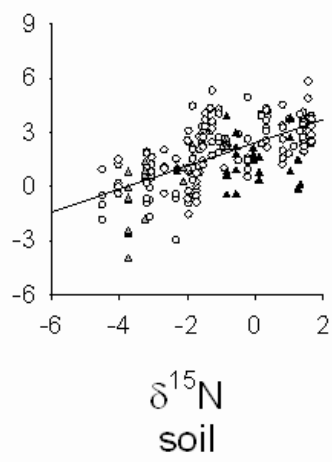

Fig. A8. Relationship between $\delta^{15} \mathrm{~N}$ signatures of resources (leaf litter, fine roots and soil) and soil animals of different trophic levels (first, second and third level consumers); for $r^{2}$ - and $p$-values see Table 1; open dots $=$ beech, black triangles $=$ spruce, grey triangles $=$ pine .

Table A1. Two-factorial ANOVA table of F-values on the effect of region and forest type on stable isotope signatures $\left(\delta^{13} \mathrm{C}, \delta^{15} \mathrm{~N}\right)$ of leaf litter, fine roots and soil; significant results are marked in bold $\left({ }^{*} p<0.05,{ }^{* *} p<0.01,{ }^{* * *} p<0.001\right)$.

\begin{tabular}{|c|c|c|c|c|c|c|}
\hline \multirow[b]{2}{*}{ Resource } & \multicolumn{2}{|l|}{ Region } & \multicolumn{2}{|l|}{ Forest type } & \multicolumn{2}{|c|}{ Region*forest type } \\
\hline & $\delta^{13} \mathrm{C}$ & $\delta^{15} \mathrm{~N}$ & $\delta^{13} \mathrm{C}$ & $\delta^{15} \mathrm{~N}$ & $\delta^{13} \mathrm{C}$ & $\delta^{15} \mathrm{~N}$ \\
\hline Leaf litter & $F_{2,36}=1.84$ & $F_{2,36}=65.01^{\star \star *}$ & $F_{3,36}=22.57^{\star \star \star}$ & $F_{3,36}=1.49$ & $F_{6,36}=1.27$ & $F_{6,36}=2.09$ \\
\hline Fine roots & $F_{2,36}=2.54$ & $F_{2,36}=17.27^{\star \star \star}$ & $F_{3,36}=9.27^{\star \star \star}$ & $F_{3,36}=1.05$ & $F_{6,36}=2.72^{*}$ & $F_{6,36}=1.56$ \\
\hline Soil & $F_{2,36}=0.89$ & $F_{2,36}=33.25^{\star \star \star}$ & $F_{3,36}=1.12$ & $F_{3,36}=0.27$ & $F_{6,36}=0.75$ & $F_{6,36}=0.32$ \\
\hline
\end{tabular}


Table A2. Stable isotope signatures $\left(\delta^{13} \mathrm{C}, \delta^{15} \mathrm{~N}\right)$ of leaf litter, fine roots and soil (means $\pm \mathrm{SD}$ ) of the four forest types in the three regions studied $(\mathrm{Alb}=\mathrm{Swabian}$ Alb, Hai $=$ Hainich, Sch $=$ Schorfheide, Conif $=$ coniferous forest, $B 30=$ young managed beech, $\mathrm{B} 70=$ old managed beech, unm $B=$ unmanaged beech) .

\begin{tabular}{|c|c|c|c|c|c|c|c|}
\hline \multirow[b]{2}{*}{ Factor Ivl. } & \multirow[b]{2}{*}{$\mathrm{N}$} & \multicolumn{2}{|l|}{ Leaf litter } & \multicolumn{2}{|l|}{ Fine roots } & \multicolumn{2}{|l|}{ Soil } \\
\hline & & $\delta^{13} \mathrm{C}$ & $\delta^{15} \mathrm{~N}$ & $\delta^{13} \mathrm{C}$ & $\delta^{15} \mathrm{~N}$ & $\delta^{13} \mathrm{C}$ & $\delta^{15} \mathrm{~N}$ \\
\hline Total & 48 & $-28.37 \pm 0.64$ & $-5.13 \pm 1.27$ & $-27.68 \pm 0.89$ & $-3.80 \pm 1.19$ & $-27.07 \pm 1.34$ & $-0.85 \pm 1.69$ \\
\hline Alb & 16 & $-28.28 \pm 0.63$ & $-4.19 \pm 0.54$ & $-27.43 \pm 0.89$ & $-2.94 \pm 0.82$ & $-26.78 \pm 1.22$ & $0.58 \pm 1.03$ \\
\hline Hai & 16 & $-28.53 \pm 0.80$ & $-4.59 \pm 0.5$ & $-27.65 \pm 1.08$ & $-3.68 \pm 0.82$ & $-27.33 \pm 1.87$ & $-0.50 \pm 1.12$ \\
\hline Sch & 16 & $-28.30 \pm 0.48$ & $-6.61 \pm 0.96$ & $-27.95 \pm 0.62$ & $-4.79 \pm 1.12$ & $-27.09 \pm 0.67$ & $-2.62 \pm 1.00$ \\
\hline Conif & 12 & $-27.53 \pm 0.48$ & $-4.83 \pm 0.94$ & $-26.87 \pm 1.11$ & $-3.82 \pm 0.80$ & $-26.49 \pm 0.90$ & $-0.83 \pm 1.71$ \\
\hline B30 & 12 & $-28.75 \pm 0.50$ & $-5.14 \pm 1.47$ & $-27.92 \pm 0.58$ & $-3.80 \pm 1.18$ & $-27.29 \pm 1.89$ & $-0.63 \pm 1.67$ \\
\hline B70 & 12 & $-28.61 \pm 0.24$ & $-5.38 \pm 1.29$ & $-28.24 \pm 0.76$ & $-4.12 \pm 1.26$ & $-27.40 \pm 1.55$ & $-1.04 \pm 1.66$ \\
\hline Unm B & 12 & $-28.6 \pm 0.43$ & $-5.19 \pm 1.43$ & $-27.67 \pm 0.41$ & $-3.47 \pm 1.49$ & $-27.09 \pm 0.56$ & $-0.90 \pm 1.93$ \\
\hline Alb, Conif & 4 & $-27.42 \pm 0.16$ & $-4.16 \pm 0.48$ & $-26.35 \pm 0.60$ & $-3.32 \pm 0.36$ & $-26.52 \pm 0.72$ & $0.37 \pm 1.00$ \\
\hline Alb, B30 & 4 & $-28.82 \pm 0.51$ & $-3.86 \pm 0.74$ & $-27.70 \pm 0.42$ & $-2.66 \pm 0.62$ & $-27.05 \pm 2.38$ & $1.24 \pm 0.34$ \\
\hline Alb, B70 & 4 & $-28.47 \pm 0.11$ & $-4.41 \pm 0.36$ & $-28.02 \pm 1.07$ & $-3.48 \pm 1.04$ & $-26.64 \pm 0.77$ & $0.38 \pm 0.90$ \\
\hline Alb, unm B & 4 & $-28.43 \pm 0.49$ & $-4.35 \pm 0.53$ & $-27.64 \pm 0.41$ & $-2.29 \pm 0.72$ & $-26.91 \pm 0.67$ & $0.35 \pm 1.60$ \\
\hline Hai, Conif & 4 & $-27.42 \pm 0.78$ & $-4.76 \pm 0.40$ & $-26.24 \pm 0.88$ & $-4.18 \pm 0.61$ & $-25.83 \pm 1.11$ & $-0.37 \pm 1.49$ \\
\hline Hai, B30 & 4 & $-28.95 \pm 0.43$ & $-4.62 \pm 0.40$ & $-28.18 \pm 0.19$ & $-3.68 \pm 0.55$ & $-28.02 \pm 2.49$ & $-0.71 \pm 0.93$ \\
\hline Hai, B70 & 4 & $-28.76 \pm 0.25$ & $-4.70 \pm 0.58$ & $-28.60 \pm 0.81$ & $-3.80 \pm 1.13$ & $-27.99 \pm 2.32$ & $-0.69 \pm 1.15$ \\
\hline Hai, unm B & 4 & $-28.99 \pm 0.25$ & $-4.30 \pm 0.65$ & $-27.57 \pm 0.39$ & $-3.07 \pm 0.75$ & $-27.46 \pm 0.62$ & $-0.22 \pm 1.29$ \\
\hline Sch, Conif & 4 & $-27.76 \pm 0.34$ & $-5.57 \pm 1.22$ & $-28.03 \pm 0.83$ & $-3.95 \pm 1.15$ & $-27.11 \pm 0.31$ & $-2.49 \pm 1.29$ \\
\hline Sch, B30 & 4 & $-28.47 \pm 0.57$ & $-6.96 \pm 0.44$ & $-27.88 \pm 0.92$ & $-5.07 \pm 0.71$ & $-26.79 \pm 0.32$ & $-2.40 \pm 0.60$ \\
\hline Sch, B70 & 4 & $-28.59 \pm 0.27$ & $-7.02 \pm 0.33$ & $-28.11 \pm 0.19$ & $-5.09 \pm 1.23$ & $-27.57 \pm 1.23$ & $-2.79 \pm 0.99$ \\
\hline Sch, unm B & 4 & $-28.37 \pm 0.25$ & $-6.90 \pm 0.95$ & $-27.80 \pm 0.50$ & $-5.06 \pm 1.29$ & $-26.89 \pm 0.16$ & $-2.82 \pm 1.33$ \\
\hline
\end{tabular}


Table A3. Full names of species, taxonomic group, affiliation to trophic level and number of replicates studied; for legend see Table A2.

\begin{tabular}{|c|c|c|c|c|c|c|c|c|c|c|c|c|c|c|}
\hline \multirow[b]{2}{*}{ Trophic level } & \multirow[b]{2}{*}{ Species } & \multirow[b]{2}{*}{ Taxonomic group } & \multicolumn{4}{|c|}{ Swabian Alb } & \multicolumn{4}{|c|}{ Hainich } & \multicolumn{4}{|c|}{ Schorfheide } \\
\hline & & & Conif & B30 & B70 & B unm & Conif & B30 & $\mathrm{B} 70$ & B unm & Conif & B30 & B70 & B unm \\
\hline \multirow{4}{*}{ 1st level consumers } & Folsomia quadrioculata (Tullberg, 1871) & Collembola & 3 & 2 & 3 & 2 & 3 & 3 & 3 & 4 & NA & NA & NA & NA \\
\hline & Lumbricus rubellus Hoffmeister, 1843 & Lumbricidae & NA & NA & NA & NA & NA & NA & NA & NA & 1 & 11 & 3 & 4 \\
\hline & Lumbricus terrestris Linnaeus, 1758 & Lumbricidae & 1 & 6 & 4 & 5 & 5 & 7 & 3 & 5 & NA & NA & NA & NA \\
\hline & Parisotoma notabilis (Schaeffer, 1896) & Collembola & 3 & 4 & 3 & 4 & 3 & 3 & 3 & 4 & 3 & 3 & 3 & 3 \\
\hline \multirow{14}{*}{ 2nd level consumers } & Allajulus nitidus (Verhoeff, 1891) & Diplopoda & 3 & 3 & 3 & 3 & 3 & 3 & 3 & 3 & NA & NA & NA & NA \\
\hline & Aporrectodea caliginosa (Savigny, 1826) & Lumbricidae & NA & NA & NA & NA & 9 & 9 & 8 & 9 & NA & NA & NA & NA \\
\hline & Aporrectodea rosea (Savigny, 1826) & Lumbricidae & NA & NA & NA & NA & 8 & 10 & 6 & 4 & NA & NA & NA & NA \\
\hline & Chamobates voigtsi (Oudemans, 1902) & Oribatida & 3 & 3 & 3 & 3 & 3 & 3 & 3 & 3 & 3 & 3 & 3 & 3 \\
\hline & Damaeus riparius Nicolet, 1855 & Oribatida & 3 & 3 & 3 & 3 & 3 & 3 & 3 & 3 & 3 & 3 & 3 & 3 \\
\hline & Eupelops hirtus (Berlese, 1916) & Oribatida & NA & NA & NA & NA & NA & NA & NA & NA & 4 & 4 & 4 & 4 \\
\hline & Isotomiella minor (Schaeffer, 1896) & Collembola & 3 & 2 & 3 & 3 & 3 & 3 & 3 & 3 & 3 & 3 & 3 & 3 \\
\hline & Lithobius mutabilis L. Koch, 1862 & Chilopoda & 3 & 3 & 3 & 2 & 2 & 3 & 3 & 4 & NA & NA & NA & NA \\
\hline & Nothrus sylvestris Nicolet, 1855 & Oribatida & NA & NA & NA & NA & NA & NA & NA & NA & 4 & 4 & 4 & 4 \\
\hline & Octolasion tyrtaeum Savigny, 1826 & Lumbricidae & 3 & 5 & 10 & 8 & 9 & 11 & 7 & 5 & NA & NA & NA & NA \\
\hline & Rhysotritia dublicata (Grandjean, 1953) & Oribatida & NA & NA & NA & NA & NA & NA & NA & NA & 4 & 4 & 4 & 4 \\
\hline & Scutigerella immacullata (Newport, 1845) & Symphyla & 4 & 2 & 4 & 3 & 2 & 3 & 3 & 8 & NA & NA & NA & NA \\
\hline & Trachytes aegrota (Koch, 1841) & Mesostigmata & 3 & 3 & 3 & 3 & 3 & 3 & 4 & 6 & 3 & 3 & 3 & 3 \\
\hline & Trichoniscus pusillus Brandt, 1833 & Isopoda & 3 & 3 & 3 & 3 & 3 & 3 & 3 & 4 & NA & NA & NA & NA \\
\hline \multirow{10}{*}{ 3rd level consumers } & Atheta fungi (Gravenhorst, 1806) & Coleoptera & NA & NA & NA & NA & NA & NA & NA & NA & 1 & 2 & 3 & 4 \\
\hline & Athous subfuscus (O. F. Muller, 1764) & Coleoptera & 3 & 3 & 3 & 4 & 3 & 3 & 3 & 3 & 3 & 3 & 2 & 1 \\
\hline & Ceratophysella denticulata (Bagnall, 1941) & Collembola & NA & NA & NA & NA & NA & NA & NA & NA & 3 & 3 & 3 & 3 \\
\hline & Geophilus ribauti Brolemann, 1908 & Chilopoda & 3 & 3 & 3 & 3 & 3 & 3 & 4 & 6 & NA & NA & NA & NA \\
\hline & Lithobius aeruginosus L. Koch, 1862 & Chilopoda & 4 & 4 & 4 & 4 & NA & NA & NA & NA & NA & NA & NA & NA \\
\hline & Pergamasus norvegicus (Berlese, 1906) & Mesostigmata & NA & NA & NA & NA & NA & NA & NA & NA & 4 & 4 & 4 & 4 \\
\hline & Schendyla nemorensis C.L. Koch, (1837) & Chilopoda & NA & NA & NA & NA & 3 & 3 & 3 & 4 & 3 & 3 & 3 & 3 \\
\hline & Strigamia acuminata Leach, (1815) & Chilopoda & 1 & 2 & 3 & 3 & NA & NA & NA & NA & NA & NA & NA & NA \\
\hline & Tapinocyba insecta (L. Koch, 1869) & Araneae & NA & NA & NA & NA & NA & NA & NA & NA & 3 & 4 & 4 & 4 \\
\hline & Veigaia nemorensis (C.L. Koch, 1839) & Mesostigmata & 3 & 3 & 3 & 3 & 3 & 3 & 3 & 6 & 3 & 3 & 3 & 3 \\
\hline
\end{tabular}


Table A4. Two-factorial ANOVA table of F-values on the effect of region and forest type on the stable isotope enrichment $\left(\Delta^{13} \mathrm{C}, \Delta^{15} \mathrm{~N}\right)$ of soil animal species ordered by trophic level; significant effects are marked in bold $\left({ }^{*} p<0.05,{ }^{* *} p<0.01,{ }^{* * *} p<0.001\right)$.

\begin{tabular}{|c|c|c|c|c|c|c|c|}
\hline \multirow[b]{2}{*}{ Trophic level } & \multirow[b]{2}{*}{ Species } & \multicolumn{2}{|l|}{ Forest type } & \multicolumn{2}{|l|}{ Region } & \multicolumn{2}{|c|}{ Region*forest type } \\
\hline & & $\Delta^{13} \mathrm{C}$ & $\Delta^{15} \mathrm{~N}$ & $\Delta^{13} \mathrm{C}$ & $\Delta^{15} \mathrm{~N}$ & $\Delta^{13} \mathrm{C}$ & $\Delta^{15} \mathrm{~N}$ \\
\hline \multirow{4}{*}{ 1st level consumers } & Folsomia quadrioculata (Tullberg, 1871) & $F_{3 ; 15}=10.25^{\star \star \star}$ & $F_{3 ; 15}=3.93^{\star}$ & $F_{1 ; 15}=0.65$ & $F_{1 ; 15}=0.75$ & $F_{3 ; 15}=3.30$ & $F_{3 ; 15}=1.29$ \\
\hline & Lumbricus rubellus Hoffmeister, 1843 & $F_{3 ; 15}=6.36^{\star \star}$ & $F_{3 ; 15}=3.61^{*}$ & NA & NA & NA & NA \\
\hline & Lumbricus terrestris Linnaeus, 1758 & $F_{3 ; 28}=6.05^{\star \star}$ & $F_{3 ; 28}=7.27^{\star \star \star}$ & $F_{1 ; 28}=0.62$ & $F_{1 ; 28}=1.84$ & $F_{3 ; 28}=2.76$ & $F_{3 ; 28}=2.64$ \\
\hline & Parisotoma notabilis (Schaeffer, 1896) & $F_{3 ; 27}=19.37^{\star \star \star}$ & $F_{3 ; 27}=11.75^{\star \star \star}$ & $F_{2 ; 27}=26.17^{\star \star \star}$ & $F_{2 ; 27}=14.78^{\star \star \star}$ & $F_{6 ; 27}=3.37^{\star}$ & $F_{6 ; 27}=0.55$ \\
\hline \multirow{14}{*}{ 2nd level consumers } & Allajulus nitidus (Verhoeff, 1891) & $F_{3 ; 16}=1.50$ & $F_{3 ; 16}=2.48$ & $F_{1 ; 16}=0.03$ & $F_{1 ; 16}=1.50$ & $F_{3 ; 16}=0.35$ & $F_{3 ; 16}=0.18$ \\
\hline & Aporrectodea caliginosa (Savigny, 1826) & $F_{3 ; 31}=3.18^{\star}$ & $\mathrm{F}_{3 ; 31}=0.95$ & NA & NA & NA & NA \\
\hline & Aporrectodea rosea (Savigny, 1826) & $F_{3 ; 24}=5.83^{\star \star}$ & $F_{3 ; 24}=2.43$ & NA & NA & NA & NA \\
\hline & Chamobates voigtsi (Oudemans, 1902) & $F_{3 ; 30}=14.56^{\star \star *}$ & $F_{3 ; 30}=3.22^{\star}$ & $F_{2 ; 30}=2.63$ & $F_{2 ; 30}=5.49^{\star}$ & $F_{6 ; 30}=1.77$ & $F_{6 ; 30}=1.36$ \\
\hline & Damaeus riparius Nicolet, 1855 & $F_{3 ; 33}=4.00^{\star}$ & $F_{3 ; 33}=0.15$ & $F_{2 ; 33}=2.84$ & $F_{2 ; 33}=2.23$ & $F_{6 ; 33}=1.26$ & $F_{6 ; 33}=1.46$ \\
\hline & Eupelops hirtus (Berlese, 1916) & $\mathrm{F}_{3 ; 12}=2.08$ & $\mathrm{~F}_{3 ; 12}=1.86$ & NA & NA & NA & NA \\
\hline & Isotomiella minor (Schaeffer, 1896) & $F_{3 ; 23}=6.76^{\star \star}$ & $F_{3 ; 23}=12.77^{\star \star \star}$ & $F_{2 ; 23}=0.96$ & $F_{2 ; 23}=0.14$ & $F_{6 ; 23}=2.34$ & $F_{6 ; 23}=2.62$ \\
\hline & Lithobius mutabilis L. Koch, 1862 & $F_{3 ; 15}=7.40^{\star \star}$ & $F_{3 ; 15}=3.93^{\star}$ & $F_{1 ; 15}=0.43$ & $F_{1 ; 15}=3.20$ & $F_{3 ; 15}=0.05$ & $F_{3 ; 15}=0.63$ \\
\hline & Nothrus sylvestris Nicolet, 1855 & $F_{3 ; 12}=13.34^{\star \star \star}$ & $F_{3 ; 12}=1.26$ & NA & NA & NA & NA \\
\hline & Octolasion tyrtaeum Savigny, 1826 & $F_{3 ; 50}=1.38$ & $\mathrm{~F}_{3 ; 50}=0.70$ & $F_{1 ; 50}=6.60^{*}$ & $F_{1 ; 50}=0.08$ & $F_{3 ; 50}=6.15^{\star *}$ & $\mathrm{~F}_{3 ; 50}=0.40$ \\
\hline & Rhysotritia dublicata (Grandjean, 1953) & $F_{3 ; 12}=4.77^{\star}$ & $F_{3 ; 12}=0.82$ & NA & NA & NA & NA \\
\hline & Scutigerella immacullata (Newport, 1845) & $F_{3 ; 20}=1.39$ & $F_{3 ; 20}=0.24$ & $F_{1 ; 20}=0.34$ & $F_{1 ; 20}=0.49$ & $F_{3 ; 20}=0.49$ & $F_{3 ; 20}=0.94$ \\
\hline & Trachytes aegrota (Koch, 1841) & $F_{3 ; 29}=31.61^{\star \star \star}$ & $F_{3 ; 29}=10.95^{\star \star \star}$ & $F_{2 ; 29}=1.57$ & $F_{2 ; 29}=0.77$ & $F_{6 ; 29}=0.92$ & $F_{6 ; 29}=0.95$ \\
\hline & Trichoniscus pusillus Brandt, 1833 & $F_{3 ; 25}=10.14^{\star \star \star}$ & $F_{3 ; 25}=3.13^{\star}$ & $F_{1 ; 25}=0.42$ & $F_{1 ; 25}=4.31^{*}$ & $F_{3 ; 25}=1.63$ & $F_{3 ; 25}=1.20$ \\
\hline \multirow{7}{*}{ 3rd level consumers } & Atheta fungi (Gravenhorst, 1806) & $F_{3 ; 6}=3.81$ & $F_{3 ; 6}=1.30$ & NA & NA & NA & NA \\
\hline & Athous subfuscus (O. F. Muller, 1764) & $F_{3 ; 21}=5.38^{\star \star}$ & $F_{3 ; 21}=9.31^{\star \star \star}$ & $F_{2 ; 21}=0.96$ & $F_{2 ; 21}=5.72^{\star}$ & $F_{6 ; 21}=0.52$ & $F_{6 ; 21}=1.83$ \\
\hline & Ceratophysella denticulata (Bagnall, 1941) & $\mathrm{F}_{3 ; 8}=1.05$ & $F_{3 ; 8}=2.62$ & NA & NA & NA & NA \\
\hline & Geophilus ribauti Brolemann, 1908 & $F_{3 ; 20}=2.04$ & $F_{3 ; 20}=2.37$ & $F_{1 ; 20}=2.15$ & $F_{1 ; 20}=1.04$ & $F_{3 ; 20}=0.97$ & $F_{3 ; 20}=3.05$ \\
\hline & Lithobius aeruginosus L. Koch, 1862 & $F_{3 ; 12}=4.37^{\star}$ & $F_{3 ; 12}=3.96^{\star}$ & NA & NA & NA & NA \\
\hline & Pergamasus norvegicus (Berlese, 1906) & $F_{3 ; 12}=18.99^{\star \star \star}$ & $F_{3 ; 12}=4.17^{\star}$ & NA & NA & NA & NA \\
\hline & Schendyla nemorensis C.L. Koch, (1837) & $F_{3 ; 17}=8.73^{\star \star \star}$ & $F_{3 ; 17}=9.85^{\star \star \star}$ & $F_{1 ; 17}=0.27$ & $F_{1 ; 17}=0.26$ & $F_{3 ; 17}=0.71$ & $F_{3 ; 17}=1.98$ \\
\hline
\end{tabular}




\begin{tabular}{|c|c|c|c|c|c|c|c|}
\hline \multirow[b]{2}{*}{ Trophic level } & \multirow[b]{2}{*}{ Species } & \multicolumn{2}{|l|}{ Forest type } & \multicolumn{2}{|l|}{ Region } & \multicolumn{2}{|c|}{ Region*forest type } \\
\hline & & $\Delta^{13} \mathrm{C}$ & $\Delta^{15} \mathrm{~N}$ & $\Delta^{13} \mathrm{C}$ & $\Delta^{15} \mathrm{~N}$ & $\Delta^{13} \mathrm{C}$ & $\Delta^{15} \mathrm{~N}$ \\
\hline & Strigamia acuminata Leach, (1815) & $F_{3 ; 5}=0.33$ & $F_{3 ; 5}=1.04$ & NA & NA & NA & NA \\
\hline & Tapinocyba insecta (L. Koch, 1869) & $F_{3 ; 11}=7.56^{\star \star}$ & $F_{3 ; 11}=2.89$ & NA & NA & NA & NA \\
\hline
\end{tabular}




\section{Supplementary material}

\section{Chapter 4}

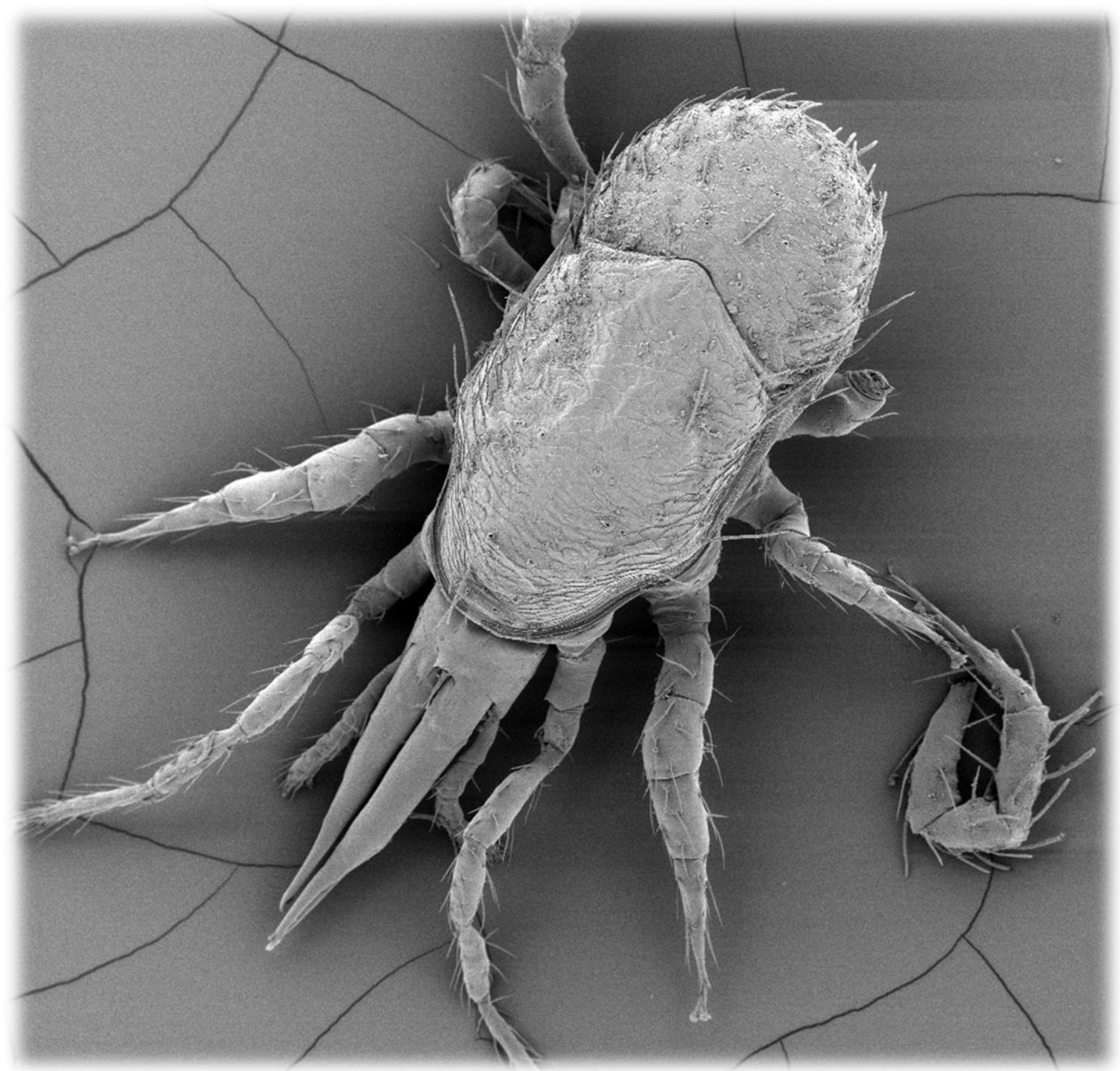


Table A1. Full taxonomic names of Mesostigmata species, family affiliation, number of samples $(\mathrm{N})$, relative abundances, dry weights of adults and stable isotope signatures (means $\pm \mathrm{SD}$ )

\begin{tabular}{|c|c|c|c|c|c|c|}
\hline Species names & Family & $\mathrm{N}$ & Rel. abund. & dry weight $[\mu \mathrm{g}]$ & $\delta^{13} \mathrm{C}[\% 0]$ & $\delta^{15} \mathrm{~N}[\% 0]$ \\
\hline Amblygamasus hamatus (C.L. Koch, 1839) & Parasitidae & 2 & $<0.01$ & $88.5 \pm 8.5$ & $-22.67 \pm 1.05$ & $5.04 \pm 0.63$ \\
\hline Amblygamasus mirabilis Willmann, 1951 & Parasitidae & 1 & $<0.01$ & 30.7 & -22.47 & 5.78 \\
\hline Arctoseius magnanalis Evans, 1958 & Ascidae & 1 & $<0.01$ & 1.7 & -23.64 & -1.13 \\
\hline Dinychus perforatus Kramer, 1886 & Dinychidae & 10 & 0.02 & $24.4 \pm 8.0$ & $-22.72 \pm 0.53$ & $3.63 \pm 0.84$ \\
\hline Epicrius canestrinii (Haller, 1881) & Epicriidae & 3 & 0.06 & $7.5 \pm 2.3$ & $-22.94 \pm 0.12$ & $2.37 \pm 1.66$ \\
\hline Geholaspis longispinosus (Kramer, 1876) & Macrochelidae & 4 & 0.01 & $65.8 \pm 5.0$ & $-23.55 \pm 0.27$ & $1.87 \pm 0.27$ \\
\hline Geholaspis mandibularis (Berlese, 1904) & Macrochelidae & 4 & 0.02 & $27.8 \pm 2.0$ & $-22.59 \pm 0.65$ & $2.97 \pm 0.2$ \\
\hline Holoparasitus stramenti Karg, 1971 & Parasitidae & 2 & 0.01 & $6.5 \pm 2.0$ & $-23.69 \pm 0.19$ & $-0.36 \pm 0.81$ \\
\hline Hypoaspis aculeifer (Canestrini, 1884) & Laelapidae & 2 & 0.01 & $5.0 \pm 6.4$ & $-23.89 \pm 0.76$ & $2.0 \pm 2.11$ \\
\hline Leitneria granulata (Halbert, 1923) & Halolaelapidae & 1 & 0.03 & 0.5 & -23.56 & -2.23 \\
\hline Leptogamasus suecicus (Trägardh, 1936) & Parasitidae & 2 & $<0.01$ & $1.7 \pm 0.5$ & $-22.83 \pm 0.22$ & $3.14 \pm 0.49$ \\
\hline Lysigamasus cf arcuatus (Dielmann, 1991 i.l.) & Parasitidae & 2 & $<0.01$ & $6.5 \pm 1.7$ & $-23.67 \pm 0.23$ & $2.83 \pm 0.47$ \\
\hline Lysigamasus lapponicus (Trägardh, 1910) & Parasitidae & 5 & 0.02 & $13.5 \pm 0.7$ & $-22.84 \pm 0.19$ & $3.43 \pm 0.44$ \\
\hline Lysigamasus minorleitneriae Athias-Henriot, 1967 & Parasitidae & 1 & $<0.01$ & 2.6 & -22.39 & 3.99 \\
\hline Macrocheles montanus (Willmann, 1951) & Macrochelidae & 4 & 0.01 & $90.9 \pm 15.1$ & $-23.72 \pm 0.48$ & $2.12 \pm 0.65$ \\
\hline Macrocheles opacus aciculatus Berlese, 1918 & Macrochelidae & 3 & 0.01 & $34.4 \pm 14.0$ & $-23.79 \pm 0.75$ & $2.13 \pm 1.08$ \\
\hline Pachylaelaps fuscinuliger Berlese, 1920 & Pachylaelapidae & 4 & 0.02 & $41.0 \pm 5.0$ & $-23.86 \pm 1.08$ & $3.52 \pm 0.97$ \\
\hline Pachylaelaps laeuchlii Schweizer, 1922 & Pachylaelapidae & 1 & $<0.01$ & 20.8 & -24.10 & 2.35 \\
\hline Pachylaelaps longisetus Halbert, 1915 & Pachylaelapidae & 3 & 0.01 & $36.3 \pm 3.8$ & $-23.62 \pm 0.44$ & $1.93 \pm 2.25$ \\
\hline Pachylaelaps regularis Berlese, 1920 & Pachylaelapidae & 3 & $<0.01$ & $5.6 \pm 0.4$ & $-23.63 \pm 0.33$ & $4.88 \pm 0.62$ \\
\hline Pachyseius angustus Hyatt, 1956 & Pachylaelapidae & 2 & 0.02 & $9.7 \pm 0.2$ & $-22.65 \pm 0.1$ & $0.45 \pm 1.07$ \\
\hline Pachyseius humeralis Berlese, 1910 & Pachylaelapidae & 3 & 0.01 & $8.7 \pm 3.1$ & $-23.0 \pm 0.78$ & $1.36 \pm 1.29$ \\
\hline Pergamasus crassipes (Linné, 1758) & Parasitidae & 2 & $<0.01$ & 77.5 & $-23.98 \pm 0.42$ & $1.65 \pm 0.07$ \\
\hline Pergamasus septentrionalis Oudemans, 1902 & Parasitidae & 1 & $<0.01$ & 142.0 & -22.97 & 3.41 \\
\hline Prozercon fimbriatus (C.L. Koch, 1839) & Zerconidae & 3 & 0.07 & $1.1 \pm 0.4$ & $-22.12 \pm 0.18$ & $1.66 \pm 1.02$ \\
\hline Rhodacarellus kreuzi Karg, 1965 & Rhodacaridae & 1 & $<0.01$ & 0.5 & -24.91 & 0.28 \\
\hline
\end{tabular}




\begin{tabular}{|c|c|c|c|c|c|c|}
\hline Species names & Family & $\mathrm{N}$ & Rel. abund. & dry weight $[\mu \mathrm{g}]$ & $\delta^{13} \mathrm{C}[\% 0]$ & $\delta^{15} \mathrm{~N}[\% 0]$ \\
\hline Trachytes aegrota (C.L.Koch, 1841) & Trachytidae & 11 & 0.08 & $8.3 \pm 1.8$ & $-22.48 \pm 0.48$ & $1.47 \pm 0.8$ \\
\hline Trachytes pauperior Berlese, 1914 & Trachytidae & 6 & 0.14 & $3.7 \pm 1.0$ & $-22.21 \pm 0.89$ & $2.65 \pm 1.59$ \\
\hline Trichouropoda ovalis (C.L.Koch, 1839) & Trematuridae & 1 & $<0.01$ & 27.0 & -23.43 & 4.68 \\
\hline Urodiaspis tecta (Kramer, 1876) & Dinychidae & 2 & $<0.01$ & 11.3 & $-23.33 \pm 0.42$ & $4.1 \pm 1.12$ \\
\hline Uropoda (Cilliba) athiasae (Hirschmann \& Zirngiebl-Nicol, 1969) & Uropodidae & 1 & $<0.01$ & 2.3 & -21.91 & 0.91 \\
\hline Uropoda (Cilliba) cassidea (Hermann, 1804) & Uropodidae & 16 & 0.07 & $37.5 \pm 1.9$ & $-22.88 \pm 0.35$ & $2.15 \pm 0.41$ \\
\hline Uropoda minima Kramer, 1882 & Uropodidae & 7 & 0.03 & $3.5 \pm 0.3$ & $-22.25 \pm 0.88$ & $3.75 \pm 1.26$ \\
\hline Uroseius cylindricus (Berlese, 1916) & Trachytidae & 10 & 0.06 & $11.8 \pm 2.1$ & $-21.99 \pm 0.41$ & $3.87 \pm 1.28$ \\
\hline Veigaia cerva (Kramer, 1876) & Veigaiidae & 3 & 0.01 & $21.3 \pm 2.1$ & $-23.72 \pm 0.66$ & $0.73 \pm 1.71$ \\
\hline Veigaia exigua (Berlese, 1917) & Veigaiidae & 1 & 0.04 & 1.3 & -23.31 & 2.94 \\
\hline Veigaia nemorensis (C.L. Koch, 1892) & Veigaiidae & 10 & 0.11 & $13.4 \pm 1.1$ & $-22.83 \pm 0.45$ & $3.87 \pm 0.44$ \\
\hline Vulgarogamasus kraepelini (Berlese, 1905) & Parasitidae & 2 & $<0.01$ & $19.8 \pm 1.2$ & $-22.79 \pm 1.25$ & $2.87 \pm 0.75$ \\
\hline Zercon gurensis Mihelcic, 1962 & Zerconidae & 5 & 0.09 & $3.0 \pm 1.1$ & $-23.33 \pm 0.14$ & $1.76 \pm 0.46$ \\
\hline Zerconopsis remiger (Kramer, 1876) & Ascidae & 1 & 0.02 & 9.2 & -23.76 & 6.54 \\
\hline
\end{tabular}


Table A2. Stable isotope signatures (means \pm SD) of Chilopoda, Diplopoda, leaf litter and soil

\begin{tabular}{llrll}
\hline & Species names/type of resource & $\mathrm{N}$ & $\delta 13 \mathrm{C}[\%]$ & $\delta 15 \mathrm{~N}[\%]$ \\
\hline \multirow{5}{*}{ Chilopoda } & 3 & $-23.06 \pm 0.62$ & $2.95 \pm 1.77$ \\
& Geophilus flavus (De Geer, 1778) & 10 & $-24.02 \pm 0.75$ & $2.65 \pm 0.62$ \\
& Geophilus ribauti Brolemann, 1908 & 5 & $-23.38 \pm 0.29$ & $2.89 \pm 0.60$ \\
& Lithobius crassipes L. Koch, 1862 & 7 & $-24.06 \pm 0.42$ & $1.21 \pm 0.41$ \\
& Lithobius mutabilis L. Koch, 1862 & 7 & $-23.83 \pm 0.8$ & $3.53 \pm 1.13$ \\
& Schendyla nemorensis (C.L.Koch, 1837) & 3 & $-23.45 \pm 0.66$ & $2.71 \pm 0.26$ \\
\hline \multirow{5}{*}{ Diplopoda } & Strigamia acuminata (Leach, 1815) & 6 & $-23.04 \pm 0.56$ & $-1.92 \pm 0.81$ \\
& Allajulus nitidus (Verhoeff, 1891) & 1 & -22.62 & -3.49 \\
& Glomeris connexa C.L.Koch, 1847 & 2 & $-23.07 \pm 0.29$ & $-5.57 \pm 1.65$ \\
\hline \multirow{2}{*}{ Resources } & Glomeris klugii Brandt, 1833 & 24 & $-28.92 \pm 0.34$ & $-4.43 \pm 0.63$ \\
& Leaf litter & 16 & $-27.1 \pm 1.20$ & $-0.46 \pm 1.23$ \\
\hline
\end{tabular}

